Argonne National Laboratory

9700 South Cass Avenue

Argonne, Illinois 60439

\title{
DYNAMIC CHARACTERISTICS OF BRIDGESTONE LOW SHEAR MODULUS-HIGH DAMPING SEISMIC ISOLATION BEARINGS
}

by

Y. W. Chang and R. W. Seidensticker

Reactor Engineering Division

June 1993 


\section{TABLE OF CONTENTS}

I. INTRODUCTION $\ldots \ldots \ldots \ldots \ldots \ldots \ldots \ldots \ldots \ldots \ldots \ldots \ldots \ldots$

II. TEST BEARINGS $\ldots \ldots \ldots \ldots \ldots \ldots \ldots \ldots \ldots \ldots \ldots \ldots \ldots \ldots$

III. TEST FACILITIES $\ldots \ldots \ldots \ldots \ldots \ldots \ldots \ldots \ldots \ldots \ldots \ldots \ldots \ldots \ldots \ldots$

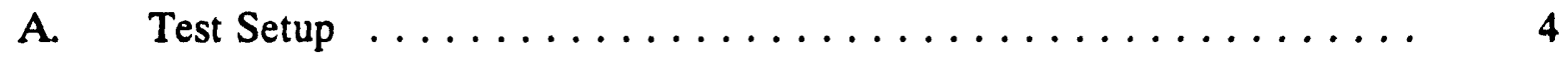

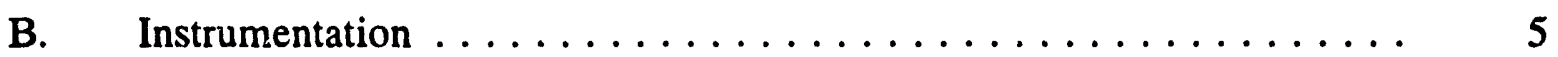

IV. TEST PROGRAM $\ldots \ldots \ldots \ldots \ldots \ldots \ldots \ldots \ldots \ldots \ldots \ldots \ldots$

A. Horizontal Tests $\ldots \ldots \ldots \ldots \ldots \ldots \ldots \ldots \ldots \ldots \ldots$

B. Vertical Tests $\ldots \ldots \ldots \ldots \ldots \ldots \ldots \ldots \ldots \ldots \ldots \ldots \ldots \ldots$

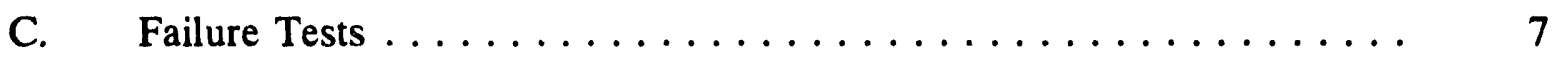

V. TEST RESULTS $\ldots \ldots \ldots \ldots \ldots \ldots \ldots \ldots \ldots \ldots \ldots \ldots \ldots \ldots \ldots$

A. Dynamic Properties Determined from the Tests $\ldots \ldots \ldots \ldots \ldots \ldots$

B. Dynamic Horizontal Properties of the Bearings $\ldots \ldots \ldots \ldots \ldots . . .9$

C. The Effect of Vertical Pressure on the Horizontal Dynamic Properties ......................... 10

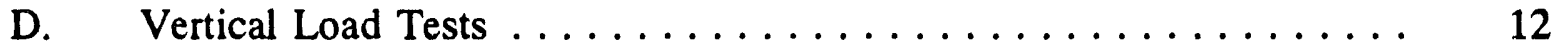

E. Shear Failure Tests $\ldots \ldots \ldots \ldots \ldots \ldots \ldots \ldots \ldots \ldots \ldots \ldots$

VI. CONCLUSIONS $\ldots \ldots \ldots \ldots \ldots \ldots \ldots \ldots \ldots \ldots \ldots \ldots \ldots \ldots \ldots$

ACKNOWLEDGMENTS $\ldots \ldots \ldots \ldots \ldots \ldots \ldots \ldots \ldots \ldots \ldots \ldots \ldots \ldots \ldots \ldots$

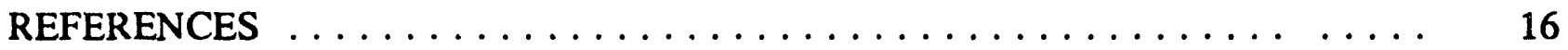

APPENDIX A. Experimental Determination of the Effective Stiffness and the Equivalent Damping Constant ................ A-1 


\section{LIST OF TABLES}

No.

Title

$\underline{\text { Page }}$

I List of Channels Used in the Single Bearing Test Machine $\ldots \ldots \ldots \ldots$

II Horizontal Shear Test of Bridgestone Bearings $\ldots \ldots \ldots \ldots \ldots \ldots \ldots \ldots$

III Vertical Load Test of Bridgestone Bearings $\ldots \ldots \ldots \ldots \ldots \ldots \ldots \ldots$ 


\section{LIST OF FIGURES}

No.

Title

Page

1 The Dimensions of the Test Bearings . . . . . . . . . . . . . 35

2 Shear Modulus as a Function of Shear Strain of Bridgestone Elastomer

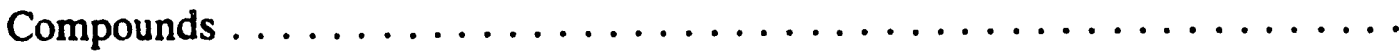

3 Viscous Damping as a Function of Shear Strain of Bridgestone Elastomer

Compounds ................................ 37

4 Details of the Single Bearing Test Machine $\ldots \ldots \ldots \ldots \ldots \ldots \ldots . \ldots 38$

$5 \quad$ Force Displacement Plots for Sequence I Tests - Zero Vertical Pressure . . . . 39

6 Force Displacement Plots for Sequence II Tests - Zero Vertical Pressure .... 40

7 Force Displacement Plots for Sequence III Tests - Zero Vertical Pressure ...

8 Force Displacement Plots for Sequence I Tests - 3.45 MPa Vertical

Pressure .............................

9 Force Displacement Plots for Sequence II Tests - 3.45 MPa Vertical

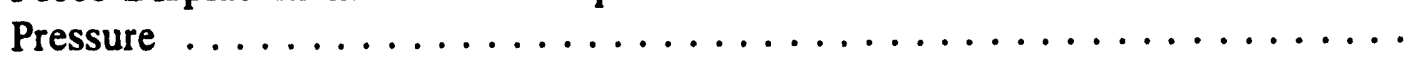

10 Force Displacement Plots for Sequence III Tests - 3.45 MPa Vertical

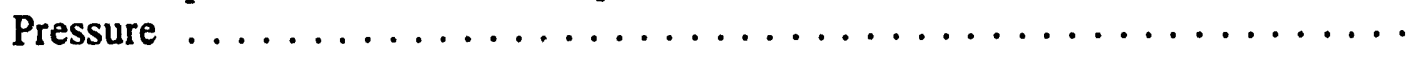

11 Force Displacement Plots for Sequence I Tests - 6.90 MPa Vertical

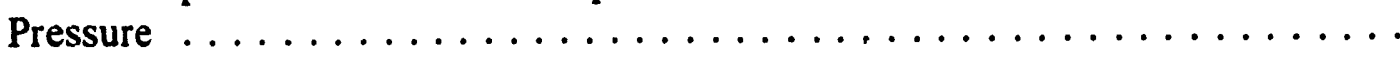

12 Force Displacement Plots for Sequence II Tests - 6.90 MPa Vertical

Pressure ............................

13 Force Displacement Plots for Sequence III Tests - 6.90 MPa Vertical

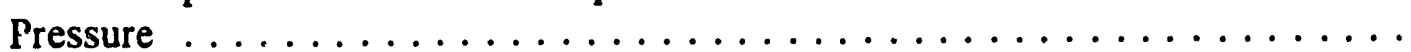

14 Force Displacement Plots for Sequence I Tests - 10.35 MPa Vertical

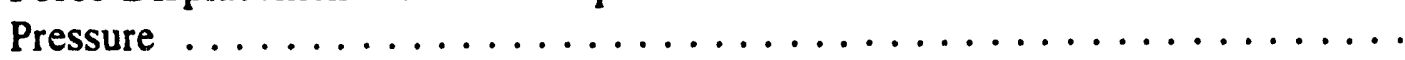

15 Force Displacement Plots for Sequence II Tests - 10.35 MPa Vertical Pressure 


\section{LIST OF FIGURES (Cont'd)}

No.

Title

Page

16 Force Displacement Plots for Sequence III Tests - 10.35 MPa Vertical

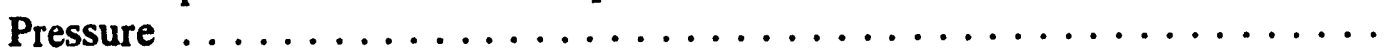

17 First Cycle Force Displacement Plots at Different Strain Levels Under

Zero Vertical Pressure $\ldots \ldots \ldots \ldots \ldots \ldots \ldots \ldots \ldots \ldots$

18 First Cycle Force Displacement Plots at Different Strain Levels Under

$3.45 \mathrm{MPa}$ Vertical Pressure $\ldots \ldots \ldots \ldots \ldots \ldots \ldots \ldots$

19 First Cycle Force Displacement Plots at Different Strain Levels Under

$6.90 \mathrm{MPa}$ Vertical Pressure . . . . . . . . . . . . . . . . .

20 First Cycle Force Displacement Plots at Different Strain Levels Under

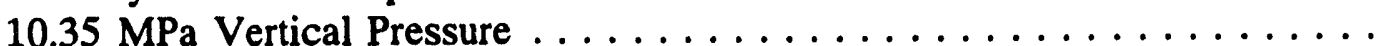

21 Effects of Vertical Pressure on the Stiffness - Strain Curves . . . . . . . .

22 Effects of Vertical Pressure on the Damping - Strain Curves .........

23 Effects of Vertical Pressure on the Energy Dissipation - Displacement

Curves

$24 \log$ (Energy Dissipation) - Log (Displacement) Curves of Bearing No. 1

Under Vertical Pressures $=3.45,6.90,10.35 \mathrm{MPa} \ldots \ldots \ldots \ldots$

25 Log (Energy Dissipation) - Log (Displacement) Curves of Bearing No. 2

Under Vertical Pressures $=3.45,6.90,10.35 \mathrm{MPa} \ldots \ldots \ldots \ldots$

26 Log (Energy Dissipation) - Log (Displacement) Curves of Bearing No. 3 Under Vertical Pressures $=3.45,6.90,10.35 \mathrm{MPa} \ldots \ldots \ldots \ldots$

27 Log (Energy Dissipation) - Log (Displacement) Curves of Bearing No. 4 Under Vertical Pressures $=3.45,6.90,10.35 \mathrm{MPa} \ldots \ldots \ldots \ldots$

28 Hysteresis Loops of Bearing No. 2 Under $3.45 \mathrm{MPa}$ Vertical Pressure . . . . .

29 Hysteresis Loops of Bearing No. 2 Under $6.90 \mathrm{MPa}$ Vertical Pressure . . . . .

30 Hysteresis Loops of Bearing No. 2 Under 10.35 MPa Vertical Pressure . . . . 


\section{LIST OF FIGURES (Cont'd)}

No.

Title

Page

31 Vertical Frequency as a Function of Axial Load .............. 65

32 Configuration of the Bearing at $0 \%$ Deformation $\ldots \ldots \ldots \ldots \ldots \ldots 6$

33 Configuration of the Bearing at $200 \%$ Deformation $\ldots \ldots \ldots \ldots \ldots 6$

34 Configuration of the Bearing at $350 \%$ Deformation $\ldots \ldots \ldots \ldots \ldots$

35 Configuration of the Bearing at $600 \%$ Deformation $\ldots \ldots \ldots \ldots \ldots$

36 Force-Displacement Curves for Bearings in Failure Tests $\ldots \ldots \ldots \ldots \ldots 68$

37 Stress-Strain Curves for Bearings in Failure Tests . . . . . . . . . . . . . . 69 


\title{
DYNAMIC CHARACTERISTICS OF BRIDGESTONE LOW SHEAR MODULUS-HIGH DAMPING SEISMIC ISOLATION BEARINGS
}

by

\author{
Y. W. Chang and R. W. Seidensticker
}

\section{INTRODUCTION}

Argonne National Laboratory (ANL) has been deeply involved in the development of seismic isolation for use in nuclear facilities for the past decade. Under the funding and direction of the U.S. Department of Energy (USDOE), ANL has been developing methodology needed to evaluate the usefulness and effectiveness of seismic isolation for advanced reactors. Seismic isolation is also growing rapidly worldwide as a cost-effective and reliable design strategy for a wide range of critical and important facilities, such as hospitals, computer facilities, data centers and emergency preparedness centers.

In the early stages, the seismic isolation elastomeric bearings were manufactured with low damping natural rubber compound and were used with supplementary dampers. As the technology evolved, the supplementary dampers have been eliminated and the damping has been incorporated in the bearings themselves by appropriate compounding. High damping rubber bearings have been used in many base isolated buildings. These bearings carry the vertical load, provide low horizontal stiffness and generate significant damping, thus obviating the need for additional mechanical energy dissipating mechanisms.

To ensure that the seismic isolation elastomeric bearings manufactured for the critical and important facilities meet the stringent design and functional requirements, ANL has tested several types of bearings manufactured by various bearing manufacturers. The first type of seismic bearings tested was a high shape factor-high shear modulus-high damping rubber bearing manufactured by Fluorocarbon (now FURON) of Texas, U.S.A. The bearings were made from a highly damped rubber compound designated by the elastomer compounder, LTV Energy Products as $243-62$. The shape factor value for those bearings is 24 , the same as those used in the General Electric (GE) Company's design of the Power Reactor Inherently Safe Module Reactor (PRISM). ANL purchased 16 bearings from Fluorocarbon: eight bearings were shipped 
to Japan for installation at Sendai test facility [1] and for laboratory testing at Shimizu Corporation; four bearings were sent to the Earthquake Engineering Research Center (EERC), University of California, Berkeley for additional laboratory tests; two bearings were shipped to the Energy Technology and Engineering Center (ETEC) for dynamic testing; and two were retained at ANL as archival samples. The results of laboratory tests are given in ANL/Shimizu Report ANL-002 [2].

The second type of seismic isolation bearings tested was a medium shape factor-high shear modulus-high damping rubber bearing manufactured by LTV Energy Products Company of Texas, U.S.A. ANL purchased 28 bearings: 14 bearings have a shape factor of 9 and the other 14 bearings have a shape factor of 18 . These bearings were made of two different elastomer compounds. One has a shear modulus of 120 psi at $100 \%$ shear strain and the other has a shear modulus of 150 psi at $100 \%$ shear strain. They are all high damping and high shear modulus elastomeric compounds. The two compounds were designated as 259-62 and 257-71 by the elastomer compounder. The laboratory tests were performed at the Earthquake Simulator Laboratory, EERC. The mechanical characteristics and failure mechanisms of these four different types of elastomeric bearings are described in detail in EERC Laboratory Report No. 91-04 [3].

The third type of bearings tested was medium shape factor-high damping-low shear modulus rubber bearings. It used a new compound developed by the Malaysian Rubber Producers Research Association (MRPRA) which has a shear modulus that is about half that of the shear modulus of the high damping rubber developed by LTV. Also, the value of the shear modulus is less dependent on the shear strain, thus improving the response of the isolated building under small earthquakes. ANL purchased ten bearings from Rubber Consultants of the United Kingdom using the newly developed compound of MRPRA. Six bearings made by Rubber Consultants were installed in the Sendai test building for earthquake observation and four bearings were used for laboratory testing. The mechanical characteristics of these low shear modulus-high damping bearings are described in ANL/Shimizu Report ANL-004 [4].

Bridgestone Company of Japan is one of the leading seismic bearing manufacturers in the world. Their bearings have very good performance records. It appears that Bridgestone's high damping bearings are made of a blend of filled natural and synthetic rubbers with fillers and plastizers whereas in the United States, the high damping compound is a carbon filled natural 
rubber. To compare the properties of the two different kinds of high damping compounds, ANL purchased eight bearings from Bridgestone: four of which were made of high shear modulushigh damping rubber compound $\mathrm{KL} 401$; the other four were made of low shear modulus-high damping rubber compounds: two with KL301 elastomer and two with KL302 elastomer.

Tests of the Bridgestone bearings were performed at EERC. The dynamic characteristics of the high shear modulus Bridgestone bearings, KL401, are described in ANL/Shimizu Report ANL-003 [5]. This report describes the dynamic and failure characteristics of the low shear modulus $\mathrm{P}:$ :dgestone bearings, KL301 and KL302.

\section{TEST BEARINGS}

The dimensions of the test bearings provided by the Bridgestone Corporation are shown in Fig. 1. The bearings have 22 thin layers of $2 \mathrm{~mm}(0.079$ in.) thick rubber and 21 steel shims which are $0.8 \mathrm{~mm}(0.031 \mathrm{in}$.) thick. The shim diameter is $240 \mathrm{~mm}$ (9.45 in.) and there is $2.5 \mathrm{~mm}$ ( $0.098 \mathrm{in}$.) of cover outside the perimeter of the shim plate. Thus, the diameter of the rubber layers is $245 \mathrm{~m}$ (9.65 in.). The bearings have two oversize end plates which permit them to be bolted to the test machine.

The compound used in the bearings is designated by Bridgestone as KL301 or KL302. They are both low shear modulus, high damping rubber. KL301 is the earlier version of low stiffness high damping elastomer material developed by the Bridgestone Corporation, whereas $\mathrm{KL} 302$ is the improved version of the low stiffness high damping elastomer material with less temperature dependency than KL301. They are a blend of natural and synthetic rubber with around 30\% carbon filler. The shear modulus and viscous damping of KL301 and KL302 are shown as a function of shear strain in Figs. 2 and 3, respectively. For the purpose of comparison, the properties of KL401 and KL501 are also shown. It should be mentioned that KL501 is a new high modulus rubber compound developed by Bridgestone to permit manufacturing of bearings with a wide range of stiffnesses. 
The identification numbers of the test bearings are given below.

\begin{tabular}{|c|c|c|}
\hline EERC ID & Bridgestone ID & Rubber Compound ID \\
\hline 1 & 68 F041Z-HR030-2 & KL301 \\
\hline 2 & $68 F 041 Z-H R 030-3$ & KL301 \\
\hline 3 & $68 F 041 Z-H R 030-5$ & KL302 \\
\hline 4 & $68 F 041 Z-H R 030-6$ & KL302 \\
\hline
\end{tabular}

The nominal vertical load of the bearings is 30 metric tons (tonnes) which corresponds to $66.2 \mathrm{kips}$ of load and $6.52 \mathrm{MPa}(945 \mathrm{psi})$ of vertical pressure. For this load, these bearings have a horizontal frequency of $0.85 \mathrm{~Hz}$ at $100 \%$ shear strain and a vertical frequency of $29.5 \mathrm{~Hz}$. This very high vertical frequency is due to the use of extremely thin rubber layers. The shape factor of these bearings is $\mathbf{3 0}$ which is also considered to be very high.

\section{TEST FACILITIES}

The test program was carried out on a single bearing test machine as shown in Fig. 4 at the Earthquake Simulator Laboratory of EERC.

\section{A. Test Setup}

The mechanical characteristic tests for the elastomeric bearings were performed in a test machine which can produce horizontal and vertical dynamic loadings simultaneously on a single bearing. The details of the test machine are described below.

The test machine consists of two rigid reaction frames supporting one horizontal actuator and two vertical actuators. The test bearing is mounted on a force transducer which measures shear force, axial force and bending moment. The force transducer is located on a braced pedestal which is attached to a base block. The base block consists of a concrete block and a wide flange steel beam to provide anchorage to the test floor. Loads are applied to the test bearing by a beam; vertical loads by two vertical actuators to simulate gravity loads on the 
bearings, and the horizontal loads by a horizontal actuator which acts along the longitudinal axis of the load beam.

The rigid pedestal is placed between the transducer and the test floor to maximize the length of the vertical actuators so that the change in the vertical load component due to horizontal displacements during testing is not significant. Two lateral struts are connected to opposite ends of the load beam to stabilize the setup in the transverse direction. For constant axial loads applied to the test bearing the vertical actuators are under force control, which means that the vertical load is maintained constant and is independent of the horizontal displacements of the load beam. In addition, the differential displacement between the two vertical actuators is maintained at zero, ensuring that the load beam is kept horizontal.

Control of the hydraulic system is performed by an MTS 443 Controller. The hydraulic actuator can develop a maximum dynamic load of $339 \mathrm{kN}(76.2 \mathrm{kips})$ at a hydraulic pressure of 20.7 MN/m² (3000 psi). The maximum travel of the horizontal actuator is $152.4 \mathrm{~mm}$ ( $\pm 6 \mathrm{in}$.) (i.e., $304.8 \mathrm{~mm}$ or $12 \mathrm{in}$. stroke). Maximum piston velocity is $770 \mathrm{~mm} / \mathrm{sec}(30.3 \mathrm{in} . / \mathrm{sec})$ and the servo-valve on the actuator has a flow capacity of $200 \mathrm{gpm}$. If displacements in excess of the $152.4 \mathrm{~mm}$ ( $\pm 6 \mathrm{in}$.) limit are required, the setup can be modified to obtain a maximum displacement of $254 \mathrm{~mm}$ (10 in.) for loading in one horizontal direction only. A maximum load of $1334.4 \mathrm{kN}$ (300 kips) can be applied by the two vertical actuators, each with a servo-valve capacity of $25 \mathrm{gpm}$.

Signal control is performed by an IBM-AT 286 personal computer. Control signals for both components of loading can be completely general in nature.

\section{B. Instrumentation}

A total of 19 channels of data were recorded for the tests of the elastomeric bearings in the single bearing test machine. The following is a brief description of the components that were measured.

The loads applied by the hydraulic actuators were measured by precalibrated load cells. The compression load on the bearing is calculated by summation of the measured forces in the two vertical actuators. Shear force, axial force and bending moment are measured by six force transducers located underneath the bearing. A linear variable differential transformer (LVDT) 
built into the horizontal actuator measures the horizontal displacement of the load beam (this being the lateral displacement of the bearing). Linear potentiometers attached to both of the vertical actuators provide feedback signals for the control of the vertical load. Four direct current differential transformers (DCDTs) measure the vertical displacements of the load beam near the corners of the top of the bearing. A complete list of channels is given in Table I.

\section{TEST PROGRAM}

\section{A. Horizontal Tests}

All bearings were subjected to the same horizontal tests which consist of three series of cyclic shear tests. They are:

$$
\begin{array}{ll}
\text { Series I } & \gamma= \pm 5 \%, \pm 10 \%, \pm 25 \%, \pm 50 \%, \pm 75 \%, \pm 100 \% \\
\text { Series II } & \gamma= \pm 100 \%, \pm 150 \%, \pm 200 \%, \pm 250 \% \\
\text { Series III } & \gamma= \pm 200 \%, \pm 250 \%, \pm 300 \%, \pm 350 \%
\end{array}
$$

where the shear strain $\gamma$ is defined as the ratio of the horizontal displacement of the bearing to the total rubber height. There were five displacement cycles for each level of strain.

Each series was repeated four times on each bearing, where the axial load was varied each time. The vertical pressures on the bearing for four axial loads were set at approximately $0,3.45$, 6.90 and $10.35 \mathrm{MPa}(0,500,1000,1500 \mathrm{psi})$.

The frequency of horizontal load in all tests was $0.5 \mathrm{~Hz}$ which is the design frequency of the isolated structures. Tests involving different load frequencies were not considered since it had already been shown in Ref. 6 that the frequency of the applying load does not have a significant effect on the dynamic properties of elastomeric bearings.

The tests were carried out in rapid succession for each bearing; between one test and the next there was a time interval of only a few minutes, which was necessary for verification of correct data acquisition and test execution. 


\section{B. Vertical Tests}

Each bearing was subjected to five cycles of vertical loading ceritered around vertical pressures of $3.45,6.90$ and $10.35 \mathrm{MPa}(500,1000,1500 \mathrm{psi})$. The variation in vertical load in each of these tests corresponded to about $\pm 0.69 \mathrm{MPa}( \pm 1 \mathrm{M}$ psi).

Since the vertical displacements due to this variation in load are of the order of magnitude of $0.2 \mathrm{~mm}$, measurement of displacement was carried out using four DCDT type transducers located between the end plates of the bearing; these transducers had an accuracy of the order of $0.025 \mathrm{~mm}$.

The frequency of the vertical load was fixed at $0.33 \mathrm{~Hz}$ for all the tests, which is the upper limit permitted by the hydraulic actuator specifications.

\section{Failure Teits}

After the horizontal and vertical dynamic tests were completed, each bearing was subjected to a combined axial compression-shear failure test. The horizontal shear load had a velocity of $4.4 \mathrm{~mm} / \mathrm{s}$ (strain velocity $10 \% / \mathrm{s}$ ). The axial compressive load was constant for each bearing. The vertical pressure of the axial compressive load in the tests was $3.45 \mathrm{MPa}$ (500 psi) for bearing nos. 1 and 3 and $6.90 \mathrm{MPa}(1000 \mathrm{psi})$ for bearing nos. 2 and 4 .

The failure strain was the shear strain at which the bearing failed. The failure load was assumed to be the maximum shear load recorded in the failure test.

\section{TEST RESULTS}

The tests were performed at EERC by Francesco Di Martino, an Italian exchange student from Universita degli Studi di Cabania. The test results are given in Ref. 7. Although the text of the test report was written in Italian, the behavior of the bearings can be interpreted from the test data, the hysteresis loups, and the force displacement curves in the failure tests given in the report. Based upon these information and translation of selected sections on test results in Ref. 7 , the dynamic characteristics of the bearings are described below. The conclusions given in this report are drawn by the authors. They may be difierent from those in Ref. 7 . 


\section{A. Dynamic Properties Determined from the Tests}

The most interesting properties that can be determined from the horizontal tests are effective stiffness and equivalent damping.

The effective horizontal stiffness is a function of the peak values of shear force and displacement and is defined as follows:

$$
K_{e f f}=\frac{F_{\max }-F_{\min }}{d_{\max }-d_{\min }}
$$

where $F_{\max }, F_{\min }, d_{\max }$ and $d_{\min }$ are the maximum and minimum values of shear force and displacement, respectively, obtained during one specific load cycle. Actually, Eq. (1) is only an approximate expression for determination of the effective stiffness, but it was used since it is easy to calculate from the data and, as shown in Appendix A, any error involved is negligible for application purposes.

The equivalent damping can be evaluated by taking into account the linear viscous-elastic behavior of the bearing. In the linear viscous-elastic model, the energy dissipated in one cycle of loading and unloading is a quadratic function of displacement.

The equivalent viscous damping of the bearings is defined as follows [8]:

$$
\beta=\frac{W_{d}}{4 \pi W_{1}}
$$

where $W_{d}=$ energy dissipated in one cycle

$$
\mathrm{W}_{1}=\text { elastic energy stored in the load cycle }=\frac{1}{2} \mathrm{~K}_{\mathrm{eff}} \mathrm{d}_{\max }^{2} .
$$

It should be noted that the behavior of the bearings is not independent of the history of the bearing load. In fact, the rubber, particularly high-damping rubber, undergoes a reversible process under the action of a load, a process known as "scragging" occurs (degradation of stiffness). When standard horizontal tests are carried out at a fixed level of shear strain it is found that the stiffness is greater in the first cycle than in successive cycles. However, the material rapidly reaches a stable condition, and the cycles following the third can be considered 
identical. Therefore the results obtained are a function of the specific load history for each bearing.

I! has been found that degradation in stiffness is not permanent effect but is a phenomenon of short duration. W. Fletcher and A. Gent were the first to observe that the dynamic stiffness of natural vulcanized rubber decreases after several strain cycles $[9,10]$. They also observed that when natural vulcanized rubber is brought to rest after a load cycle its stiffness gradually increases over time, reaching its initial value after about 24 hours at ambient temperature. Subsequent research has shown that the recovery time could be less $[11,12]$.

All of this indicates that the high-damping rubber may exhibit a deterioration in stiffness through repeated high-strain load cycles, but it will recover the original stiffness value after a short resting period. Thus, the scragging effect causes some difficulties for investigation of the dynamic characteristics of elastomeric bearings.

\section{B. Dynamic Horizontal Properties of the Bearings}

The values of $K_{\text {eff }}$ and $\beta$ were determined from the hysteresis loops using the relations described above, the energy dissipation per cycle, $W_{d}$, was calculated by numerically evaluating the area within the hysteresis loop, and the shear modulus $G$ was calculated by inverting the equation normally used to determine the shear stiffness of the bearings:

$$
K_{e f f}=\frac{G A}{T_{r}}
$$

where $\mathrm{A}=$ area of the cross section of the bearing

$T_{r}=$ total height of the bearing rubber.

The effective stiffness $K_{\text {eff }}$, the equivalent viscous damping $\beta$, the energy dissipation per cycle $W_{d}$ and the shear modulus $G$ for the first and fifth cycles of each strain level are given in Table II, in which the average values for the same quantities in the second, third and fourth cycles are also shown.

The loads and the displacements for the cycles at $5 \%$ of shear strain are very small and are close to the transducer limit. Thus, the accuracy of the results at $5 \%$ shear strain is less than 
the values obtained with larger strain. As a consequence, the results for cycles at $5 \%$ of shear strain are not included in the table, even though these cycles are shown in the figures.

The graphs showing the relationship between load and displacement of bearing no. 1 for Series I, II and III are shown in Figs. 5, 6 and 7 for zero vertical pressure, in Figs. 8, 9 and 10 for vertical pressure of $3.45 \mathrm{MPa}$ (500 psi), in Figs. 11, 12 and 13 for vertical pressure of 6.90 $\mathrm{MPa}(1000 \mathrm{psi})$ and in Figs. 14, 15 and 16 for vertical pressure of $10.35 \mathrm{MPa}(1500 \mathrm{psi})$. Since numerous tests were carried out, the results for other bearings are not presented.

These figures indicate clearly the change in the shape of the hysteresis loops with an increase in strain amplitude. The shape of the loops is initially elliptical, in good approximation, whereas the increase in the strain amplitude causes the loops to become elongated and to exhibit two parallel sides and significant sharpening at ends.

One also notes the reduction in equivalent damping with the increase of strain amplitude, which is a function of the hardening of the material when strain exceeds $200 \%$. Furthermore, for these types of elastomers the energy dissipation is not a quadratic function of the displacement amplitude but varies approximately with an exponent equal to about 3/2.

An important aspect related to bearing behavior is the fact that the energy dissipation increases with an increase in strain and that the considerable hardening of the elastomer eliminates the possibility of the premature failure of the bearing due to resonance response to low frequency earthquake components.

The bearing hysteresis loops of bearing no. 4, obtained at different levels of strain, are shown in Figs. 17, 18, 19 and 20, where only the first loop for each strain level is shown. These diagrams indicate that it is convenient to use two equivalent viscous models: an initial model for analyzing the response of the system for design earthquakes, where the strains do not exceed $200 \%$, and a second model for extreme events where the strains exceed $200 \%$.

\section{The Effect of Vertical Pressure on the Horizontal Dynamic Properties}

The bearings used for seismic isolation are generally designed for a vertical pressure of 5 to $7 \mathrm{MPa}(700-1000 \mathrm{psi})$. However, a much lower pressure level of $1.72 \mathrm{MPa}$ (250 psi) has also been proposed for very conservative designs.

The bearings having a low shape factor are considerably affected by the vertical pressure since the vertical load for these bearings constitutes a significant fraction of the critical bearing 
load. For bearings of the type manufactured by Bridgestone, which have a high shape factor, the critical load is much greater than the vertical design load and therefore the effect of vertical load is negligible compared with the equilibrium stability.

The horizontal dynamic tests were carried out at four different levels of vertical pressure: $0,3.45,6.90$ aid $10.35 \mathrm{MPa}(0,500,1000$ and $1500 \mathrm{psi})$. The effective stiffness and equivalent damping as a function of strain and srtical load are shown in Figs. 21 and 22, respectively. As can be seen from Fig. 21, $t^{r}$, effective stiffness is virtually independent of the magnitude of the vertical load. But the magnitude of the vertical load has a considerable effect on damping. The diagram given in Fig. 22 shows clearly the effect of pressure on the damping factor. It should be mentioned that the data relating to low strain values (less than 5\%) are not very accurate and should be ignored. The average values of equivalent damping for bearing no. 2 are $13.2 \%$ at 0 $\mathrm{MPa}(0 \mathrm{psi}), 15 \%$ at $3.45 \mathrm{MPa}(500 \mathrm{psi}), 16.3 \%$ at $6.90 \mathrm{MPa}(1000 \mathrm{psi})$ and $21.9 \%$ at $10.35 \mathrm{MPa}$ $(1500 \mathrm{psi})$. The values for the other bearings do not differ much from these of bearing no. 2 given above.

The equivalent damping value of the Bridgestone bearings proves to be very large, especially when compared with the high-damping bearings made by other manufacturers. For those bearings the damping factor, among other things, was also found to be dependent on strain, namely, it decreases with an increase in strain. The fact that the Bridgestone elastomers KL301 and $\mathrm{KL} 302$ have a very high damping factor value over a considerable range of strains represents a significant development in the technology of rubber production for seismic bearings.

As a consequence of these results, the use of higher pressures for the bearings should be encouraged in the future, since by increasing the pressure one increases the damping value without introducing any collateral negative effects of any significance (at least for the bearings with a high shape factor).

The damping factor was calculated, as already stated, on the basis of the linear viscouselastic model, which predicts a quadratic dependence of energy dissipation on displacement and an independence of the elastic energy from equivalent stiffness. But it has already been shown in Fig. 21 that the effective stiffness is a function of the displacement, and moreover, as shown in Fig. 23, the energy dissipation is not a quadratic function of displacement. 
To determine the relationship between energy dissipation per cycle and strain amplitude, the following procedure is proposed.

Assuming that

$$
\frac{W_{d}}{d_{\max }^{\alpha}}=\text { constant }
$$

that is, that the energy dissipation is a function of displacement raised to an unknown power $\alpha$.

By means of a simple transformation of Eq. (4) one obtains:

$\ln \left(W_{d}\right)=\alpha \ln \left(d_{\max }\right)+$ constant

which represents the equation for a line having the slope $\alpha$. It is possible to find the empirical value for $\alpha$.

Figures 24, 25, 26 and 27 show the relationship between the natural logarithm of energy dissipation and the natural logarithm of displacement for different values of vertical pressure acting on the four tested bearings.

The average values for $\alpha$, as determined from the slope of the lines, are as follows: 1.54 for the bearings made of the elastomer KL301 and 1.56 for the bearings made of the elastomer KL302. From these results one can see that the mechanical behavior of the bearings tested cannot be represented analytically by viscous or hysteretic models, but rather it is necessary to use a nonlinear model.

\section{Vertical Load Tests}

Each bearing was subjected to five cycles of vertical loading corresponding to $\pm 0.70 \mathrm{MPa}$ ( $\pm 100 \mathrm{psi}$ ) centered on $3.45 \mathrm{MPa}(500 \mathrm{psi}), 6.90 \mathrm{MPa}(1000 \mathrm{psi})$ and $10.35 \mathrm{MPa}(1500 \mathrm{psi})$. The frequency of vertical loading was fixed at $.33 \mathrm{~Hz}$. The resulting hysteresis loops for bearing no. 2 are shown in Figs. 28, 29 and 30. The area of the loops was measured and the equivalent damping is around $9 \%$ at $3.5 \mathrm{MPa}(500 \mathrm{psi}), 14 \%$ at $6.90 \mathrm{MPa}(1000 \mathrm{psi})$ and $18 \%$ at $10.35 \mathrm{MPa}$ (1500 psi). The effective vertical stiffnesses determined from these tests for all four bearings are summarized in Table III. The measured stiffnesses are sensitive to the average vertical pressure. 
The stiffness increases with pressure over the range of vertical pressures tested. The vertical frequency as a function of the axial load is shown in Fig. 31.

\section{E. Shear Failure Tests}

Each bearing was subjected to a monotonic shear load at a velocity of $4.4 \mathrm{~mm} / \mathrm{s}$ (strain velocity $10 \% \mathrm{~s}^{-1}$ ) until it failed. The configurations of the bearing at $0,200 \%, 350 \%$ and $600 \%$ of shear strains during the test are shown in Figs. 32, 33, 34 and 35. Figure 36 shows the forcedisplacement curves for these tests.

Since there are two bearings which were made of the same material, the shear failure tests can be performed at two different vertical loading conditions to study the effects of vertical pressure on the shear failure. Thus, one bearing was tested at a vertical pressure of $3.45 \mathrm{MPa}$ (500 psi) and the other was tested at a vertical pressure of $6.90 \mathrm{MPa}(1000 \mathrm{psi})$.

For bearings no. 1 and no. 2, which were made of the type KL301 elastomer, failure was instantaneous and occurred at a shear strain of about $700 \%$. It is possible that for this type of elastomer the failure mode is not influenced by the vertical pressure, although a greater number of tests would be required to confirm this conjecture.

Bearings nos. 3 and 4, made of the type KL302 elastomer, were also tested at vertical pressures of $3.45 \mathrm{MPa}(500 \mathrm{psi})$ and $6.90 \mathrm{MPa}(1000 \mathrm{psi})$. For bearing no. 3 failure occurred instantaneously at a shear strain of about $600 \%$, while for bearing no. 4 the maximum value of shear force, which was reached at a strain of about $500 \%$, does not coincide with the failure shear strain. The failure of bearing no. 4 occurred at a shear strain of $600 \%$, slightly less than bearing no. 3. It seems that for this type of elastomer the failure mode can be influenced by the vertical pressure. Of course, a large number of tests would be required to confirm this conjecture.

It one examines the force-displacement curves shown in Fig. 36, one also sees that the axial load on the bearing influences the shear stiffness, and in fact the slope of the four curves increases with an increase in vertical pressure. The failure mechanism for all bearings involved tearing of the rubber in the stressed zone; separations in the bond between elastomer and steel shim plate were never detected. It is interesting to note that for these bearings the displacement at failure exceeds the diameter of the bearing itself. 
The behavior of the bearing in terms of stress and strain is shown in Fig. 37, which indicates that for the bearings tested the stress-strain relation can be effectively approximated by a trilinear curve. The first segment of the trilinear curve extends from zero to about $10 \%$ of the shear strain, the second segment includes strains from 10\% to $250 \%$ (approximately), and the third and last segment extends from about $250 \%$ to failure.

The higher initial stiffness is important so that the building will not experience large displacement and excessive vibrations under the action of the wind load. For analysis of the design basis earthquake, the initial stiffness can be disregarded and the system can be analyzed as an viscous-elastic system with a stiffness value equal to that of the second segment of the trilinear curve and a damping value obtained from the area of the hysteresis loop relative to the strain considered. In the case of beyond the design basis earthquakes, the system response can be analyzed by means of a nonlinear analytical procedure, using a bilinear model both for the elastic forces and the viscous forces.

\section{CONCLUSIONS}

The experimental tests have confirmed the high quality of the Bridgestone bearings. These bearings have been proved to be capable of withstanding large shear strains while under high axial loads.

The failure mechanism and the shear stiffness are only slightly affected by the vertical pressure acting on the bearing. The equivalent damping of the bearing, although increasing with vertical pressure on the bearing, is virtually independent of the shear strain amplitude. This is in contrast to fundings of other commercial bearings where equivalent damping value decreases with an increase in strain amplitude.

It should be noted that the effect of seismic isolation using elastomeric bearings is due essentially to the difference of the fundamental frequencies of the structures that are conventionally founded and seismically isolated. When the ratio of these two frequencies is great, the participation factors of the higher modes are small. This means that the displacements due to an earthquake are almost entirely associated with the fundamental mode of the isolation system. But the participation factor of higher modes increases with increasing damping value of bearing. Thus, damping in the isolation bearings will increase the stress of the isolated 
structure. However, damping is necessary in order to limit displacements of the isolated structure in the event of a resonant response.

In the bearing tests it was found that the shear stiffness of the bearing increases considerably beyond the $250 \%$ strain. Therefore, if the $200 \%$ strain is taken as the design basis strain for bearings and the base shear corresponding to $200 \%$ of bearing shear strain is taken as the design basis lateral force for the structure, then the elastomeric bearings will have a considerable reserve of strength compared with the structure. This implies that the structural collapse will precede the failure of the bearings.

The most important result of the failure test of these bearings is the fact that the bearing was able to sustain horizontal (shear) displacements, while under design vertical load, that exceeded the diameter of the bearing. The maximum shear strain developed at the failure of bearing is $600 \%$ for bearings made of $\mathrm{KL} 302$ compound and $700 \%$ for bearings made of KL301 compound, which has far exceeded the design limit of $200 \%$ shear strain currently used in the bearing design.

\section{ACKNOWLEDGMENTS}

The authors wish to thank Mr. Francesco Di Martino, Professor J. M. Kelly and the staff of the Earthquake Engineering Research Center (EERC) for performing the bearing tests and for providing the test results and to Mr. Roger Busch of the Los Angeles Office of Bridgestone Corporation for providing information on Bridgestone's elastomer compounds.

This work was performed in the Engineering Mechanics Program of the Reactor Engineering Division of Argonne National Laboratory under the auspices of the U.S. Department of Energy under contract W-31-109-Eng-38. 


\section{REFERENCES}

1. Y. W. Chang and R. W. Seidensticker, "Summary Report of Joint U.S./Japanese Full-Size Building Tests for Base Seismic Isolation," ANL/Shimizu Report ANL-007, September 1991.

2. J. M. Kelly, I. D. Aiken and D. Clyde, "Peíformance Evaluation of ANL Sendai Beáring," ANL/Shimizu Report ANL-002, September 1989.

3. J. M. Kelly and E. Quiroz, "Mechanical Characteristic and Failure Mechanisms of Moderate Shape Factor Isolation Bearings," UCB/EERC Laboratory Report No. 91-04, June 1991.

4. J. M. Kelly, "Mechanical Characteristic of Low Modulus High Damping Natural Rubber Isolators for a Base Isolated Demonstration Building," ANL/Shimizu Report ANL-004, June 1991.

5. J. M. Kelly, "Dynamic and Failure Characteristic of Bridgestone Bearings," ANL/Shimizu Report ANL-003, March 1991.

6. J. E. Cole, "The Effect of Frequency, Amplitude and Load on the Dynamic Properties of Elastomers," Shock and Vibration Bulletin, Vol. 49, pp. 105-107 (1979).

7. F. D. Martino, "Deteminazione Sperimental delle Caratteristiche Statiche e Dinamiche di un Moderno Dispositivo per l'isolamento Sismico," a thesis presented to Univerita Degle Studi di Cantania, Facolta di Ingegneria, in the academic year 1991-92.

8. R. W. Clough and J. Penzien, Dynamics of Structures, McGraw Hill (1975).

9. W. P. Fletcher and A. N. Gent, "Measurement of the Dynamic Properties of Rubber," Trans. Institution Rubber Industry, Vol. 26, p. 45 (1950).

10. W. P. Fletcher and A. N. Gent, "Non-Linearity in Dynamic Properties of Vulcanized Rubber Compounds," Trans. Institution Rubber Industry, Vol. 29, p. 266 (1953).

11. A. R. Payne, "The Dynamic Properties of Carbon Black Loaded Natural Rubber Vulcanizates - Part I," Journal of Applied Polymer Science, Vol. 57 (1962).

12. A. R. Payne, "Strainwork Dependence of Filler Loaded Vulcanizates," Journal of Applied Polymer Science, Vol. 8, p. 2661 (1964). 
Table I. List of Channels Used in the Single Bearing Test Machine

\begin{tabular}{||c|l|l|l||}
\hline $\begin{array}{c}\text { Channel } \\
\text { Number }\end{array}$ & \multicolumn{1}{|c|}{$\begin{array}{c}\text { Channel } \\
\text { Name }\end{array}$} & \multicolumn{1}{c|}{$\begin{array}{c}\text { Quantity } \\
\text { Measured }\end{array}$} & \multicolumn{1}{c|}{$\begin{array}{c}\text { Channel } \\
\text { Units }\end{array}$} \\
\hline 0 & horiz. load & horiz. actuator load & kips \\
\hline 1 & horiz. disp. & horiz. actuator displ. & inches \\
\hline 2 & vload 1 & vert. actuator 1 load & kips \\
\hline 3 & vload 2 & vert. actuator 2 load & kips \\
\hline 4 & vdisp 1 & vert. actuator 1 displ. & inches \\
\hline 5 & vdisp 2 & vert. actuator 2 displ. & inches \\
\hline 6 & dcdt NE & top plate displ. NE (corner) & inches \\
\hline 7 & dcdt NW & top plate displ. NW (corner) & inches \\
\hline 8 & dcdt SE & top plate displ. SE (corner) & inches \\
\hline 9 & dcdt SW & top plate displ. SW (corner) & inches \\
\hline 10 & vpm\#8 moment2 & force trasd. moment load & kip-inches \\
\hline 11 & vpm\#8 shear2 & force trasd. shear load & kips \\
\hline 12 & vpm\#8 axial & force trasd. axial load & kips \\
\hline 13 & vpm\#7 moment 2 & force trasd. moment load & kip-inches \\
\hline 14 & vpm\#7 shear2 & force trasd. shear load & kips \\
\hline 15 & vpm\#7 axial & force trasd. axial load & kips \\
\hline 16 & frame flex & horiz. bottom plate displ. & inches \\
\hline 17 & back up horiz. & horiz. actuator displ. & inches \\
\hline 18 & beam accel. & load beam acceleration & g \\
\hline & & & \\
\hline
\end{tabular}

NB: $S E=$ South East

SW $=$ South West

$\mathrm{NE}=$ North East

NW $=$ North West 


\begin{tabular}{|c|c|c|c|c|c|c|c|}
\hline \multirow{14}{*}{ 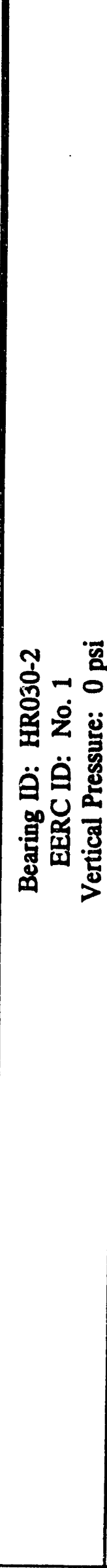 } & \multirow{4}{*}{ 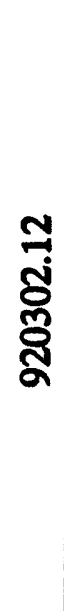 } & $\begin{array}{l}82 \\
\text { ल }\end{array}$ & \& & 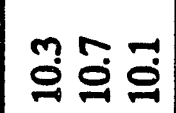 & 品宓 & $9 \%$ & \\
\hline & & हृ & 穴 & ำ & 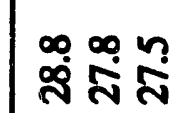 & m $q$ 요 & \\
\hline & & है & 욱ำ & ํำ & 주유 & ஜ 7 \& & \\
\hline & & ళ్రి & 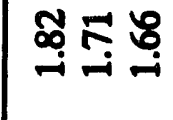 & 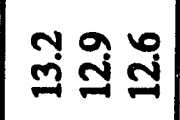 & రo & \& \% Y & \\
\hline & \multirow{4}{*}{ 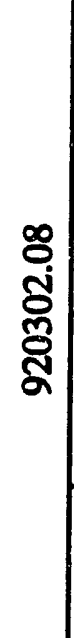 } & ㅇํํ & œ્ન & 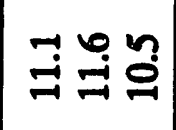 & సิํํำ & 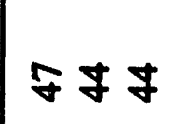 & \\
\hline & & ষ্ণ & வ & ํㅓำ & $\ddot{n} \tilde{n}$ & 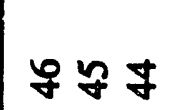 & \\
\hline & & $\begin{array}{l}8 \\
0 \\
\end{array}$ & 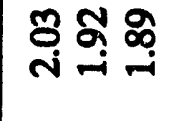 & $\tilde{N} \tilde{\sim}$ & 뭉ㅎํ용 & 岳 g & \\
\hline & & $\begin{array}{l}80 \\
8\end{array}$ & 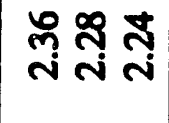 & $\ddot{m} \tilde{m} \ddot{m}$ & 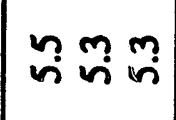 & 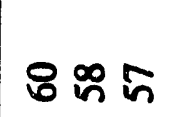 & \\
\hline & \multirow{5}{*}{ 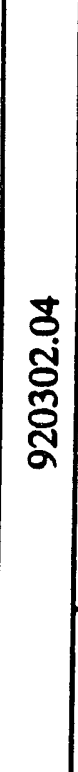 } & $\stackrel{8}{8}$ & 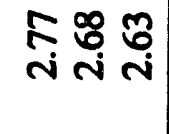 & 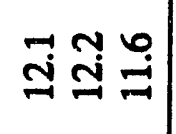 & 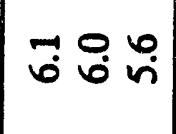 & 유 & \multirow{6}{*}{ 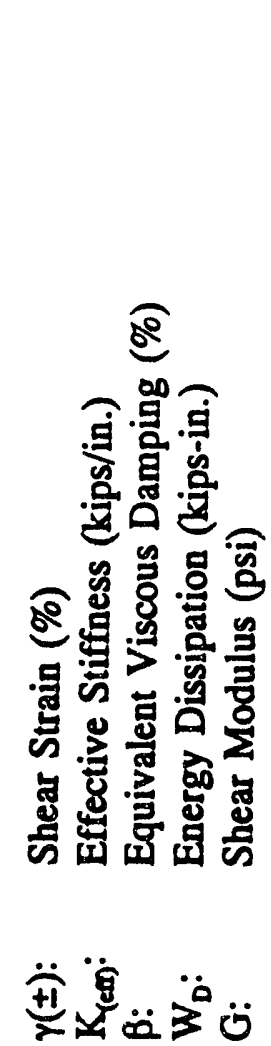 } \\
\hline & & $\stackrel{50}{5}$ & 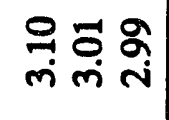 & 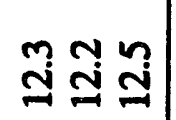 & $\stackrel{a}{m} \stackrel{\infty}{m} \stackrel{\infty}{m}$ & ㅁำ & \\
\hline & & 总 & 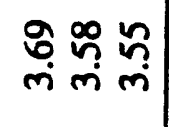 & 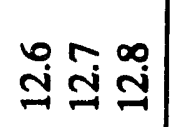 & $\vec{N} \vec{N}$ & ম் 형 & \\
\hline & & $5^{\circ}$ & 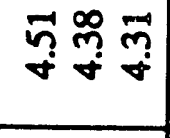 & 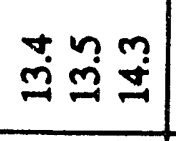 & 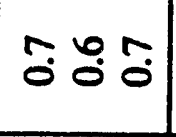 & $\stackrel{n}{\Xi} \equiv$ & \\
\hline & & $8^{8}$ & $\begin{array}{l}\vec{n} \\
\text { n̊ } \\
\text { viv }\end{array}$ & 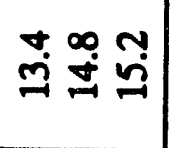 & $\overrightarrow{0} \dot{0} \overrightarrow{0}$ & $\tilde{m} \tilde{m}$ & \\
\hline & $\begin{array}{l}\dot{0} \\
\dot{z} \\
\dot{0}\end{array}$ & $\underset{2}{ \pm}$ & 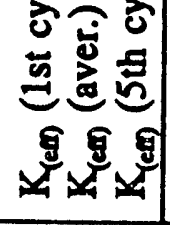 & 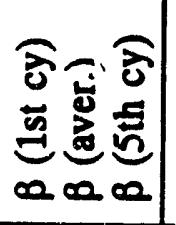 & 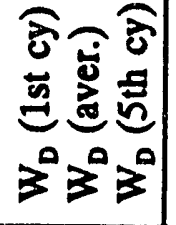 & 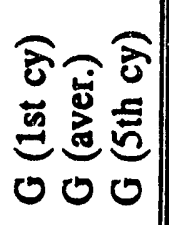 & \\
\hline
\end{tabular}




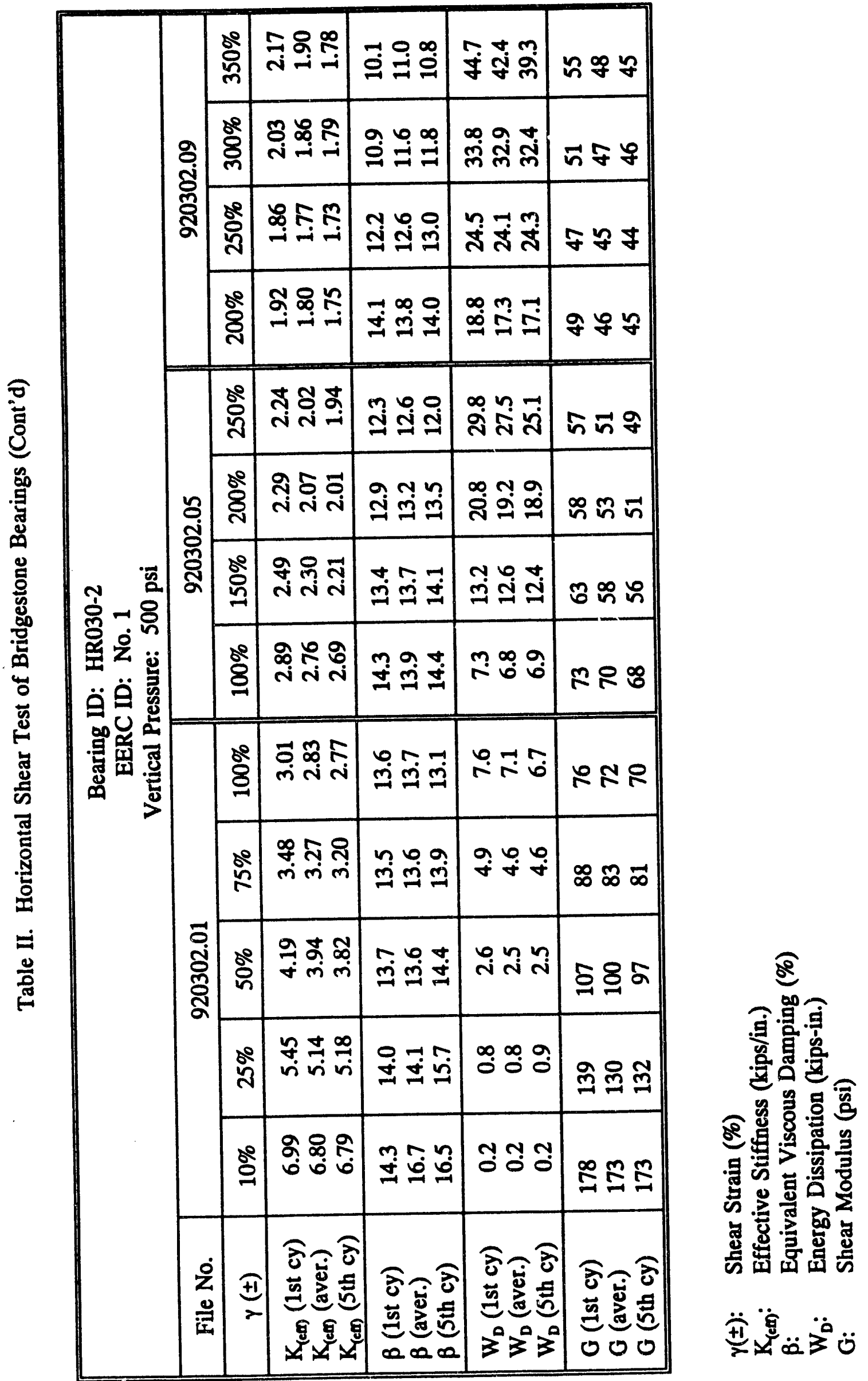




\begin{tabular}{|c|c|c|c|c|c|c|}
\hline \multirow{14}{*}{ 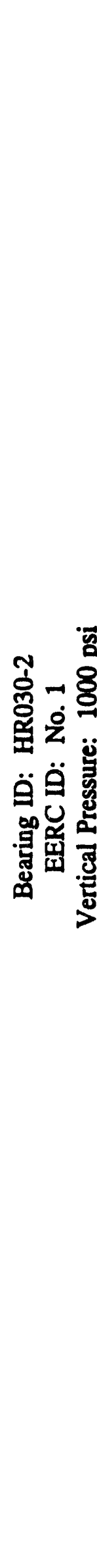 } & \multirow{4}{*}{ 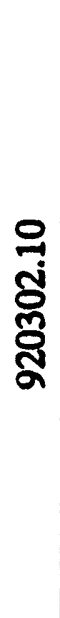 } & $\begin{array}{l}5 \\
\stackrel{2}{\circ} \\
\text { ñ }\end{array}$ & ำ & $\ddot{m} \ddot{m}$ & 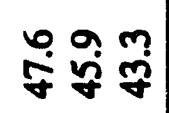 & ケ $\%$ \\
\hline & & $\sum_{m}^{80}$ & 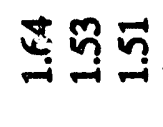 & 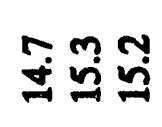 & 占品品 & Na \\
\hline & & $\begin{array}{l}8 \\
\text { กิ }\end{array}$ & ஸุ & 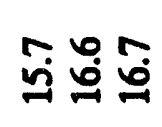 & 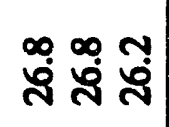 & 守 \\
\hline & & ళ్ల & 8 ஸุ & 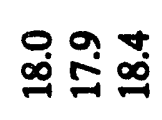 & ธิ่ & N $\& \infty$ \\
\hline & \multirow{4}{*}{ 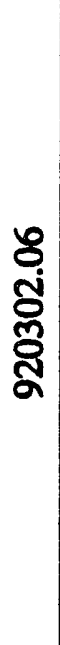 } & $\begin{array}{l}8 \\
\frac{7}{7}\end{array}$ & \&్త & 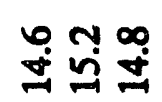 & $\begin{array}{l}m+\infty \\
\dot{m} \\
\dot{m}\end{array}$ & 동 \\
\hline & & $\overbrace{8}^{\circ}$ & $\underset{\sim}{\mathscr{\alpha}} \underset{-1}{\infty}$ & mo & జ̛̉ & g g $q$ \\
\hline & & $\begin{array}{l}89 \\
0 \\
:=1\end{array}$ & 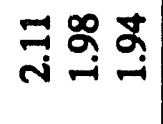 & $\stackrel{\infty}{\sim} \underset{\infty}{\infty}$ & 봎욤 & 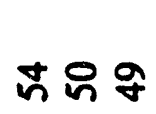 \\
\hline & & 8 & 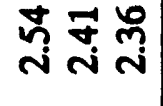 & $\underset{\infty}{\infty} \infty$ & 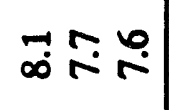 & $\curvearrowleft$ бㅇ \\
\hline & & $\stackrel{8}{8}$ & $\begin{array}{l}\tilde{0} \\
\dot{m} \tilde{N}\end{array}$ & $\ddot{m} \tilde{m}$ & 뭉 & NN \\
\hline & & $\frac{50}{n}$ & 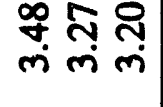 & 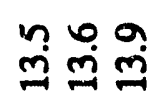 & $\begin{array}{lll}9 & 0 & 0 \\
\dot{f} & + & +\end{array}$ & $\infty ळ \infty$ \\
\hline & ర్ల & $\stackrel{5}{0}^{\circ}$ & 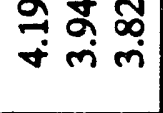 & 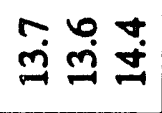 & 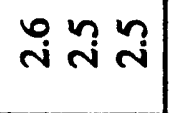 & s 8 a \\
\hline & & ปั & 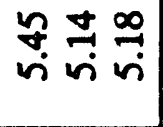 & 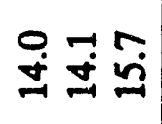 & $\stackrel{\infty}{0} \stackrel{\infty}{0} \stackrel{a}{0}$ & ్ㅣㄹㅛㅛ ్ㅐ \\
\hline & & S̊요 & $\begin{array}{l}2 \\
6 \\
6\end{array}$ & 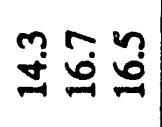 & 뚱 꿍 & $\stackrel{\infty}{\Perp} \underset{\Xi}{\varpi}$ \\
\hline & $\begin{array}{l}\dot{0} \\
\dot{Z} \\
\dot{0}\end{array}$ & $\underbrace{ \pm 1}_{2}$ & 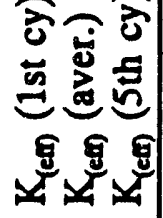 & 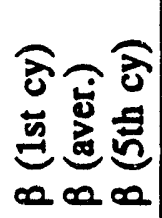 & 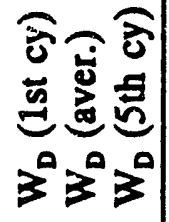 & 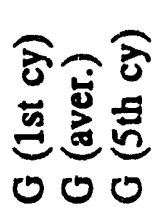 \\
\hline
\end{tabular}

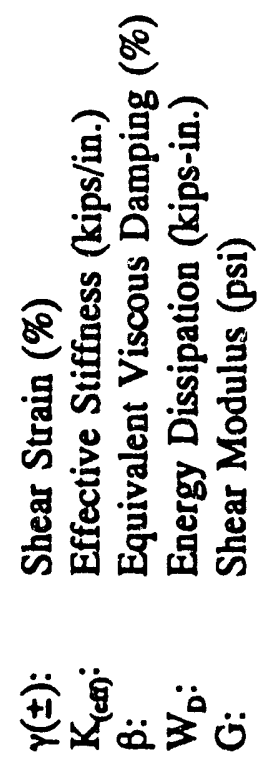




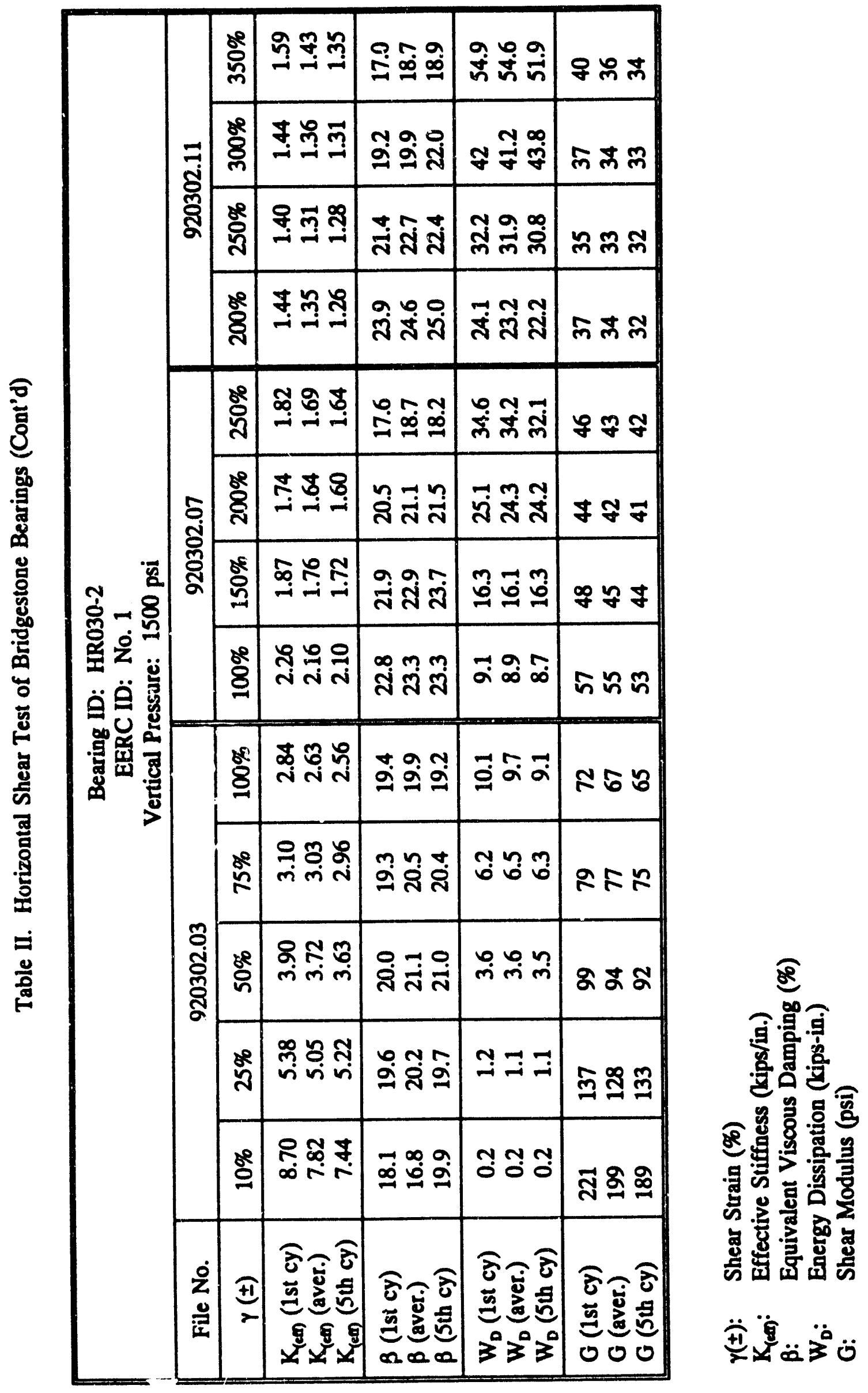


22

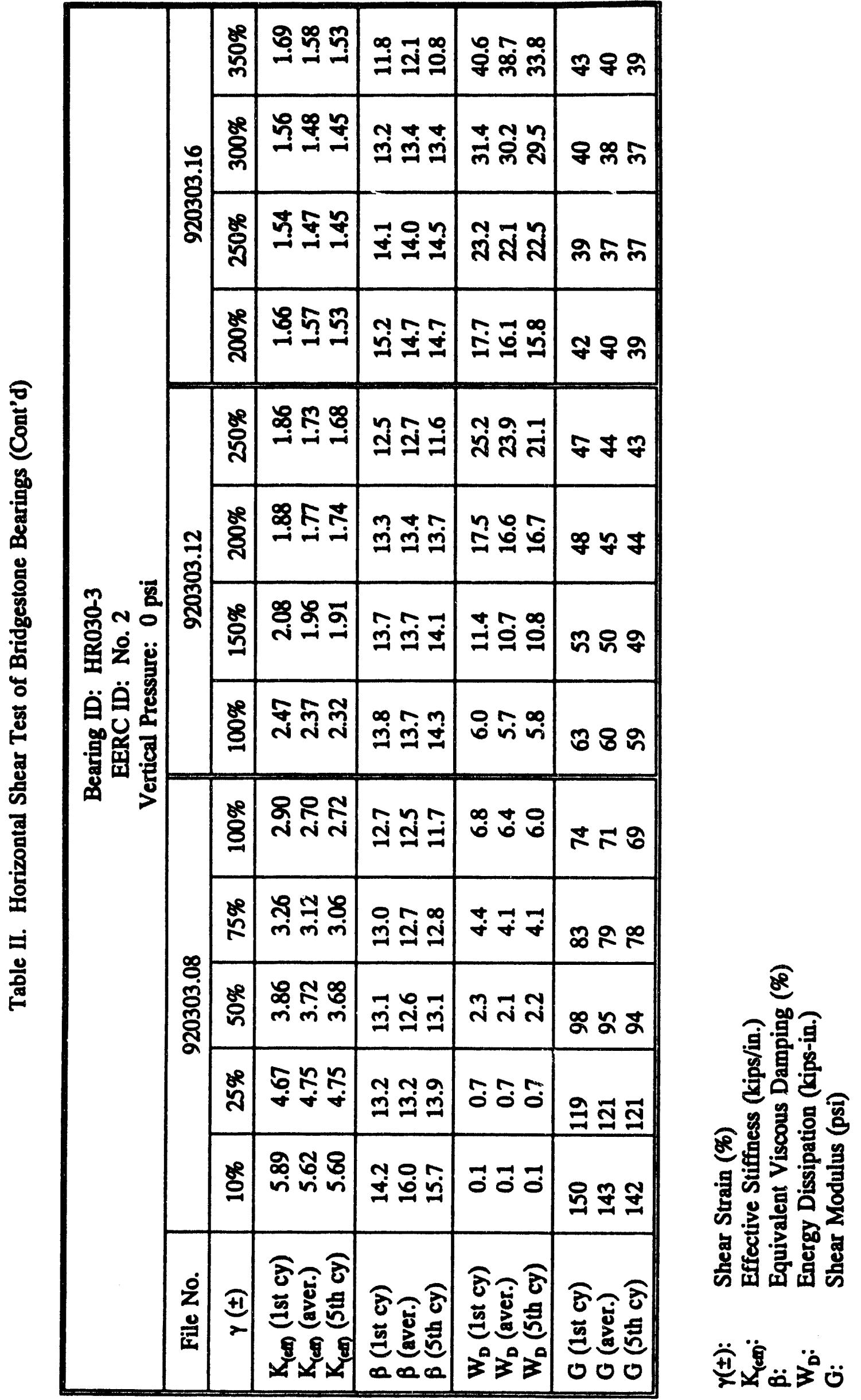




\begin{tabular}{|c|c|c|c|c|c|c|}
\hline \multirow{14}{*}{ 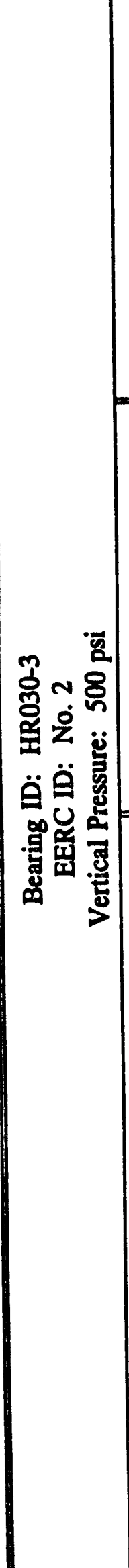 } & \multirow{4}{*}{ 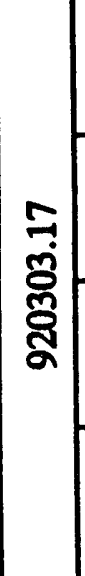 } & $\begin{array}{l}8 \\
8 \\
\end{array}$ & $\vec{n} \underset{-1}{\tilde{n}}$ & $\underset{n}{+\infty}$ & ํㅜㄹ & 赵 n \\
\hline & & $\sum_{j}^{8}$ & 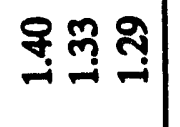 & 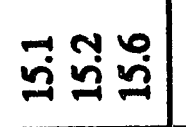 & Ny & లో సా m \\
\hline & & รి & 出 & 엉 & 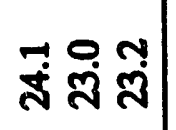 & mั \\
\hline & & ళ్రి & №̣ & $\begin{array}{l}\infty \\
0 \\
0\end{array}$ & $\begin{array}{lll}\infty & 0 & 0 \\
& \bar{\sigma} & 0\end{array}$ & ్ㅏ \\
\hline & \multirow{4}{*}{ 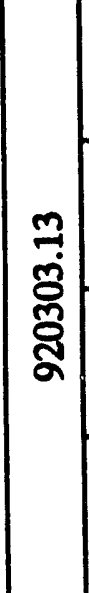 } & ㅇํํ & $\stackrel{n}{\sim} \underset{-}{\sigma}$ & 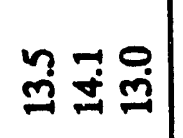 & సิ సิ & $\mathscr{\gamma}$ \\
\hline & & శ్ & 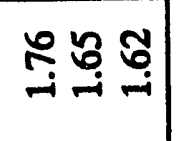 & ஸี & 0 & 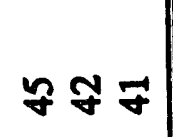 \\
\hline & & 욤 & 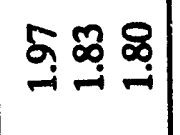 & 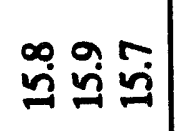 & 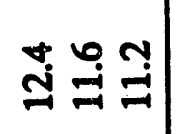 & ㅇํㄴ \\
\hline & & $\begin{array}{l}80 \\
8 \\
8\end{array}$ & m̃ & $\begin{array}{lll}\infty & 0 & 0 \\
n & 0 & 0\end{array}$ & b & 8 的年 \\
\hline & \multirow{5}{*}{ 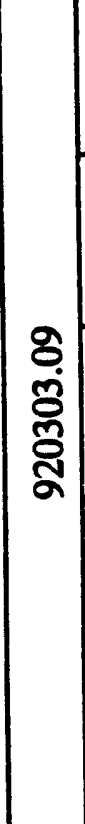 } & ర్రి & 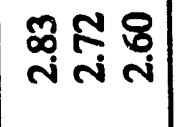 & 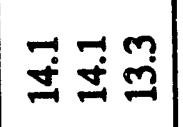 & 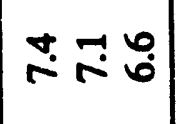 & 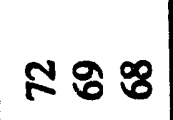 \\
\hline & & $\stackrel{8 R}{2}$ & 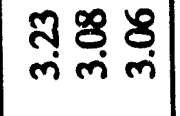 & 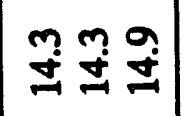 & $\mid \begin{array}{lll}\infty & 0 & \pi \\
\dot{+} & + & +\end{array}$ & న్రాథ \\
\hline & & $8^{2}$ & 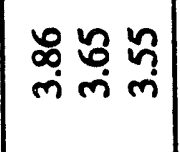 & $\begin{array}{ll}+\infty & + \\
\dot{ \pm} & \sim\end{array}$ & 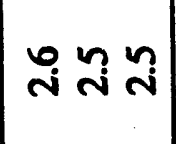 & ஃ̊요 \\
\hline & & ลั & $\underset{+}{*} \tilde{F}$ & nุํำ & $\stackrel{a}{0} \stackrel{\infty}{0}^{\infty}$ & ํ్ㄱ శ్తి శ్తి \\
\hline & & 8 & 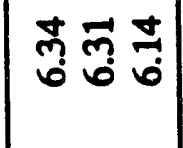 & 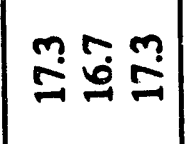 & 뚱 ํㅜㅇ & 훙 8 \\
\hline & $\begin{array}{l}\dot{0} \\
\dot{Z} \\
\dot{1}\end{array}$ & $\underset{2}{ \pm 1}$ & 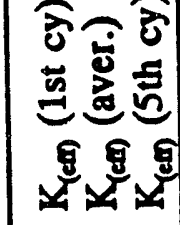 & 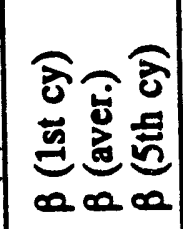 & 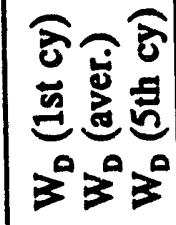 & 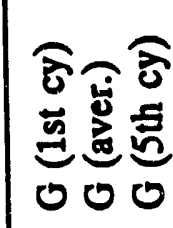 \\
\hline
\end{tabular}

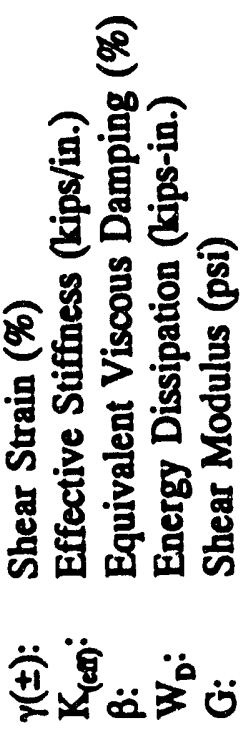




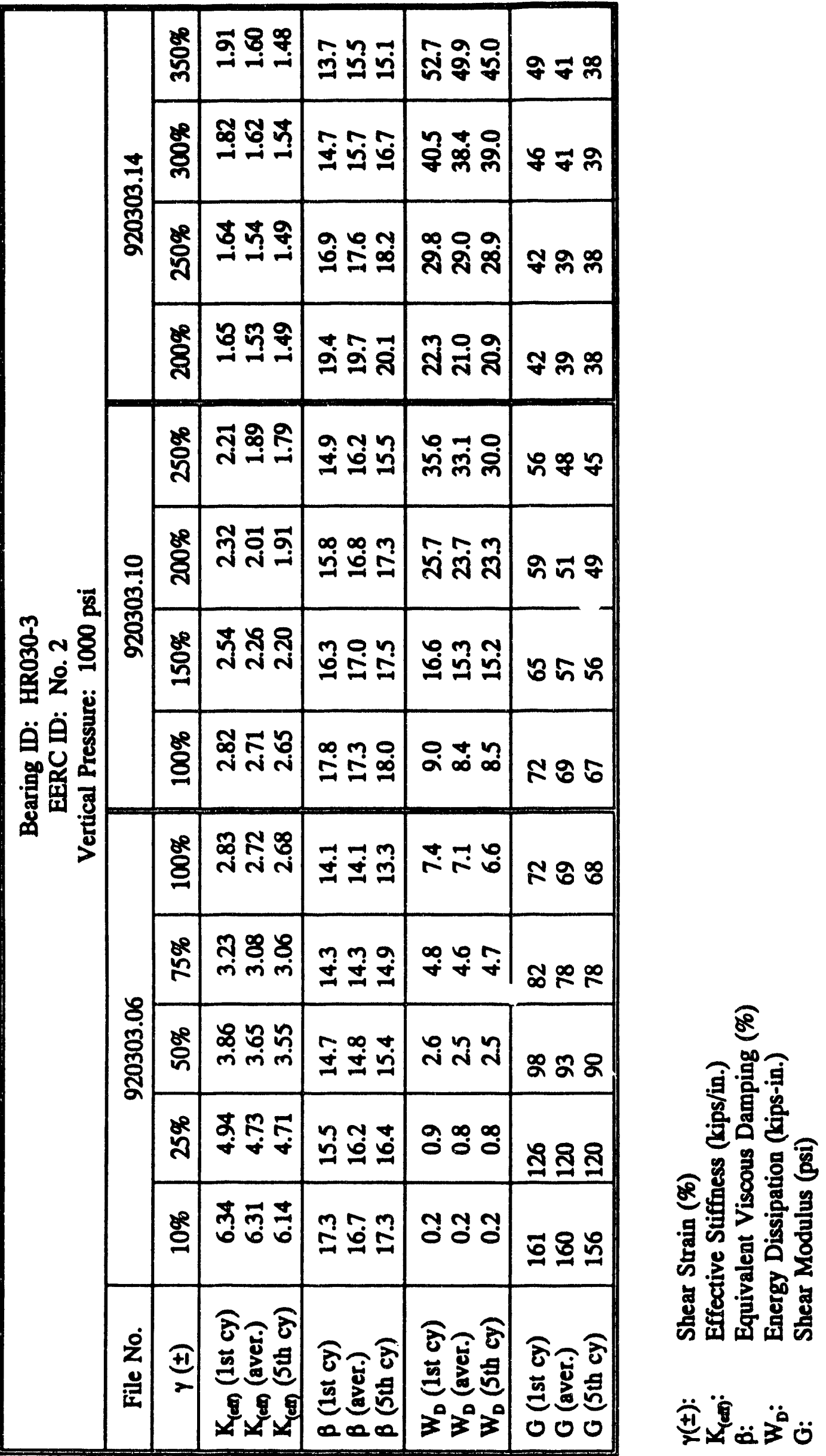




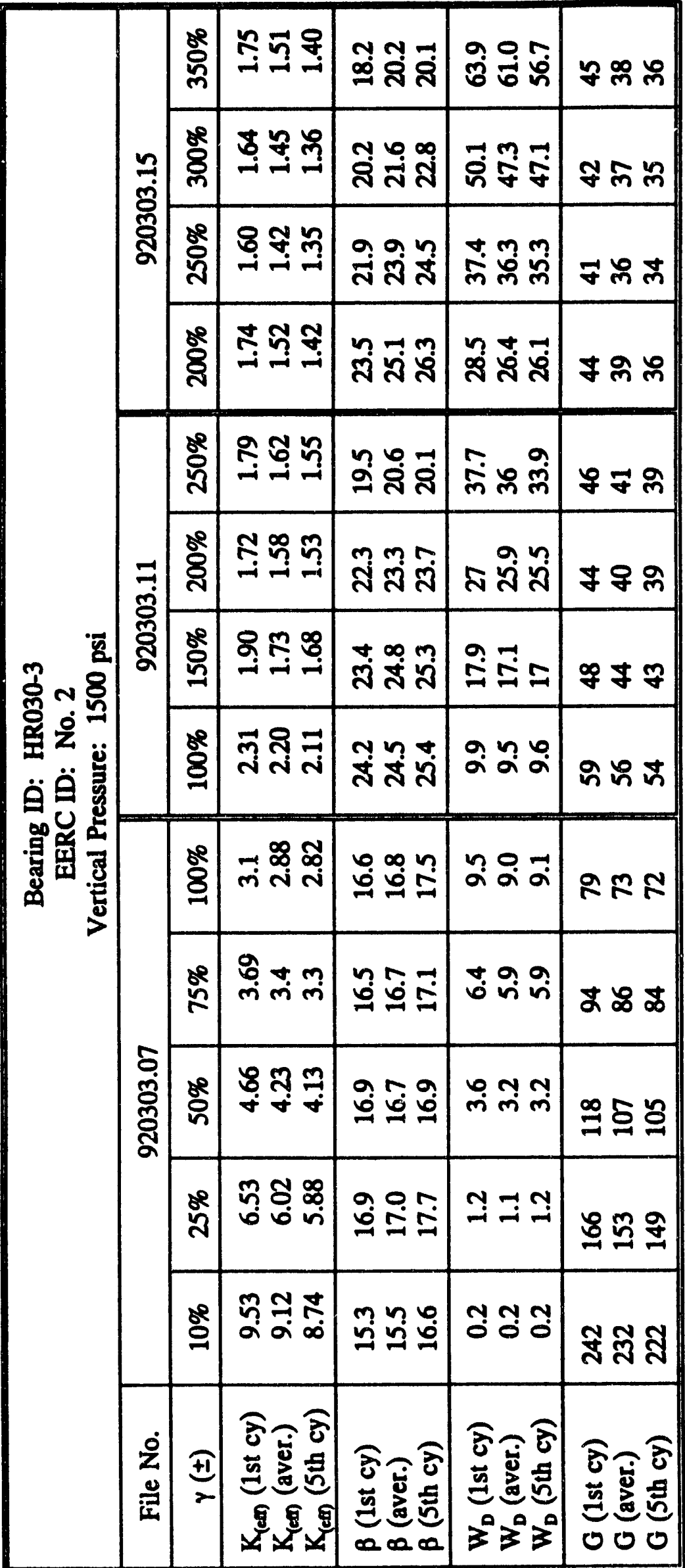

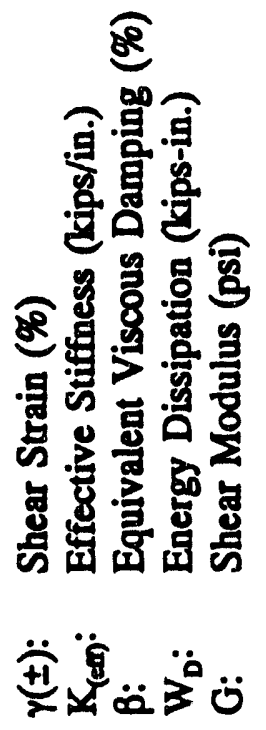




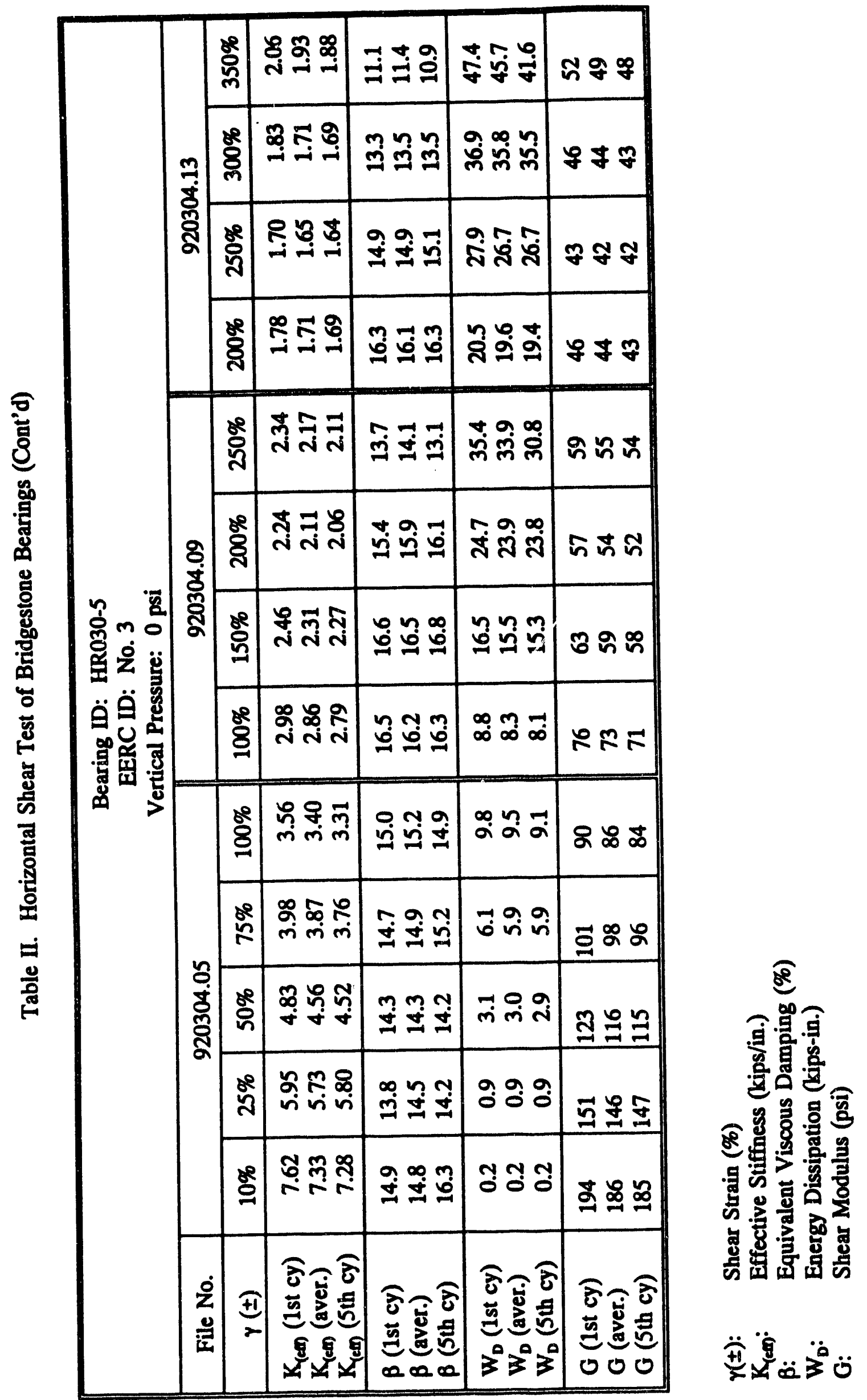




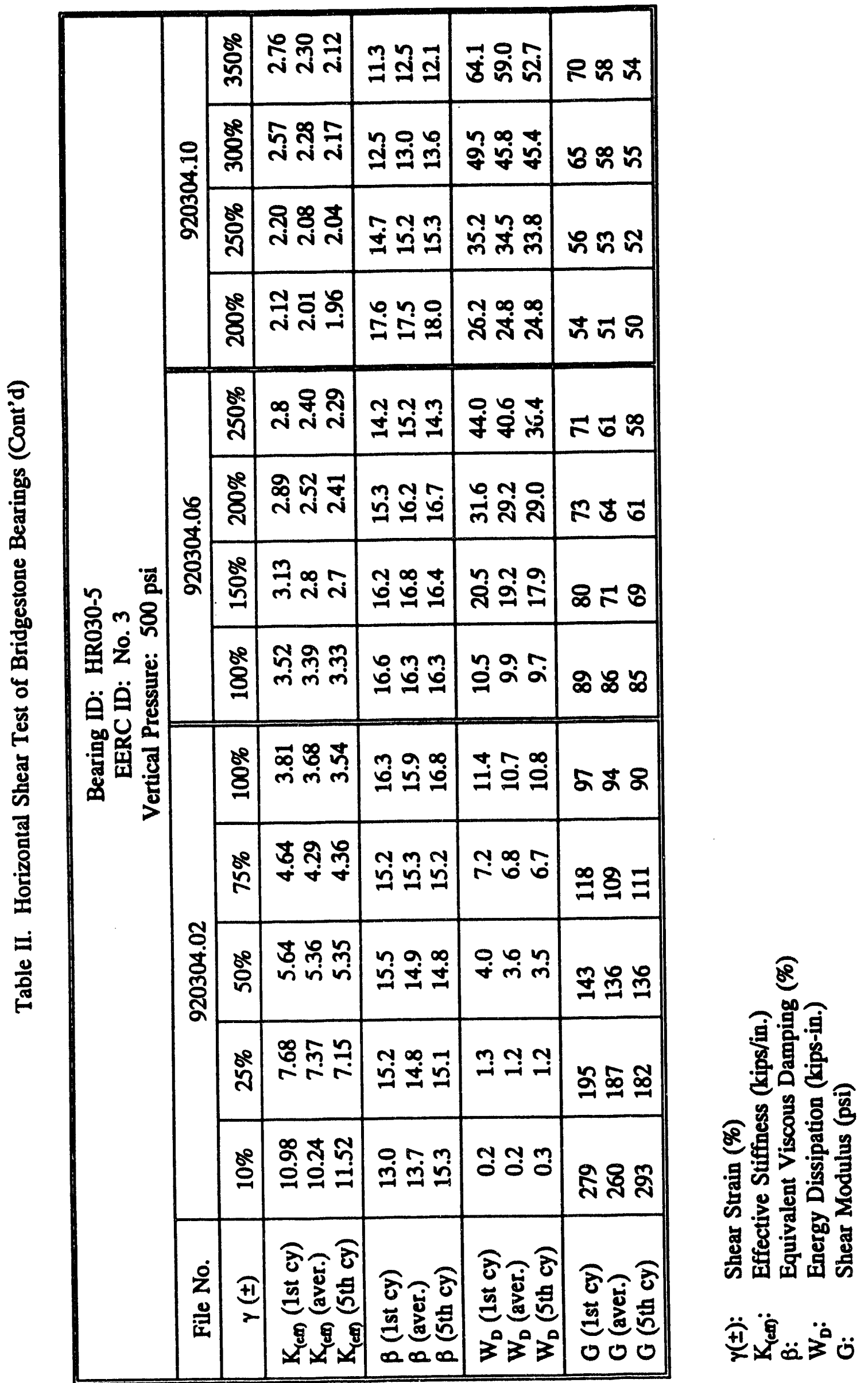




\begin{tabular}{|c|c|c|c|c|c|c|}
\hline \multirow{14}{*}{ 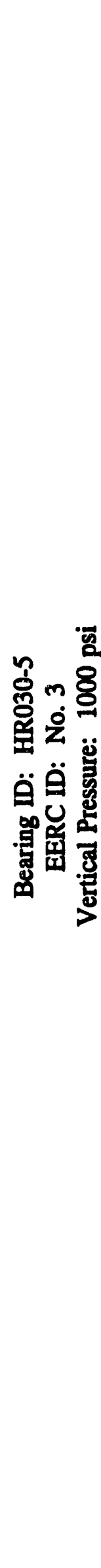 } & \multirow{4}{*}{ 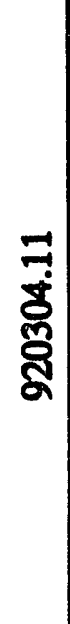 } & 总 & 둑: & 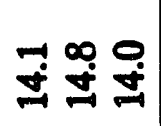 & 엉 ్ㅗㅇ & nূ요 \\
\hline & & हृ & $\stackrel{8}{\mathbb{N}} \mathbb{N}$ & 움풒 & 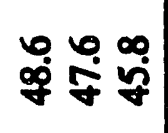 & $\forall \forall \forall$ \\
\hline & & $\frac{82}{8}$ & 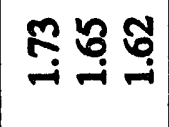 & 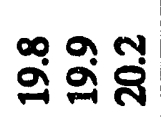 & 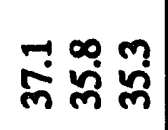 & $\forall \mathcal{F}$ \\
\hline & & $\frac{8}{8}$ & ס્ּ & 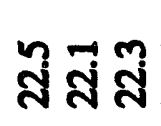 & 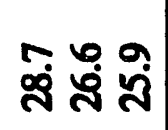 & \& 7 \\
\hline & \multirow{4}{*}{ 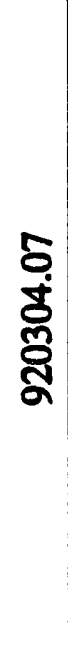 } & है & 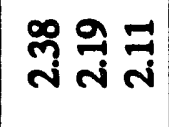 & 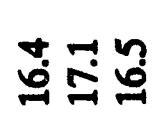 & 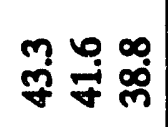 & 8 ஸ゚ చั \\
\hline & & క్ల & $\begin{array}{l}N \underset{1}{N} \mathscr{0} \\
\text { N }\end{array}$ & $\begin{array}{l}0 \\
\infty \\
\infty\end{array}$ & 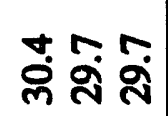 & 車苂 \\
\hline & & 总 & 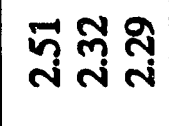 & 요융 & 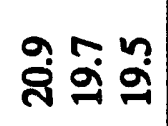 & オ \\
\hline & & 8 & 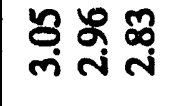 & 옷용 엇 & 궁워 & $\stackrel{\Re}{\mathfrak{N}}$ \\
\hline & \multirow{5}{*}{ 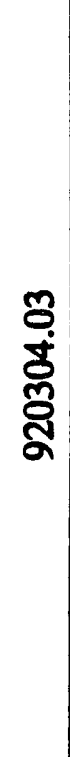 } & $8_{8}^{8}$ & 鬲守导 & a & 봃 & ズ\& \\
\hline & & $\frac{5}{2}$ & 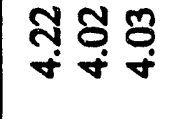 & ํㅛㅁㅍㅛ & 궁요 & ธ్웡 엉 \\
\hline & & $\frac{8}{n}$ & ஸ & 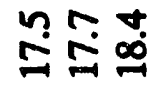 & $\stackrel{0}{\circ} \stackrel{9}{\dot{\gamma}} \stackrel{0}{\dot{\gamma}}$ & 일 జి \\
\hline & & ปู & 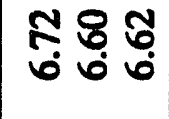 & 두욤 & $m+\underset{-}{m}$ & $\mp \mathscr{8}$ \\
\hline & & 8̊ & ઠீ: & 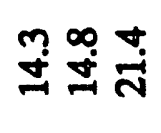 & 뚜 & 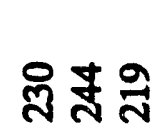 \\
\hline & $\begin{array}{l}\dot{0} \\
\dot{y} \\
\dot{1}\end{array}$ & $\underset{2}{\pi}$ & 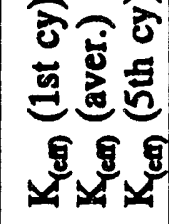 & 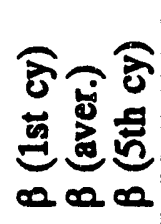 & 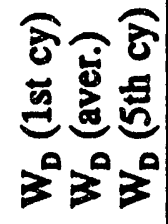 & 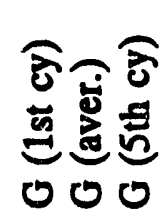 \\
\hline
\end{tabular}

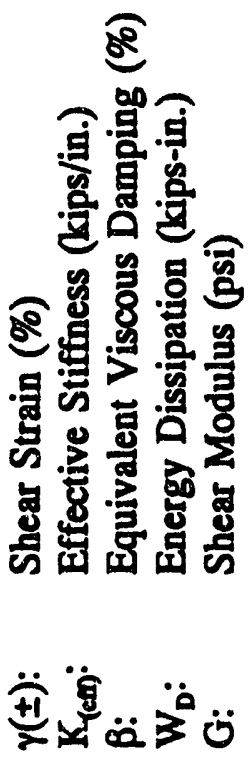




\begin{tabular}{|c|c|c|c|c|c|c|}
\hline \multirow{14}{*}{ 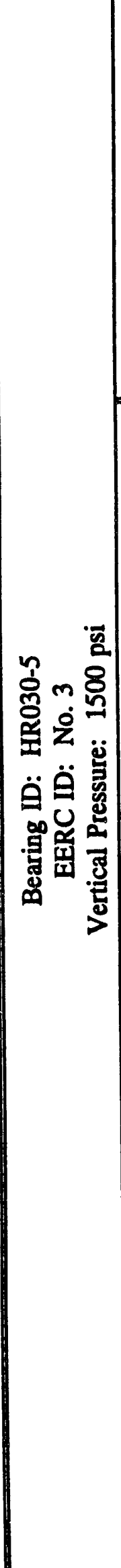 } & \multirow{4}{*}{ 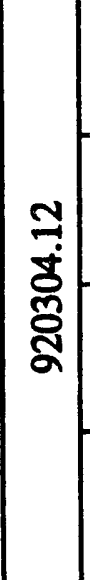 } & 号 & 宓 & \begin{tabular}{ccc}
$m$ & $\infty$ \\
\cline { 1 - 1 } & $\infty$ & $\infty$ \\
$=$ & $\infty$
\end{tabular} & 웅 & 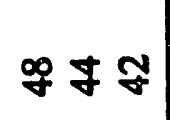 \\
\hline & & క్లి & 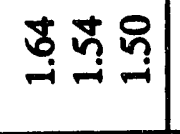 & @̊ & 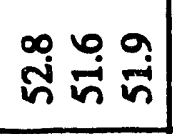 & 요 \\
\hline & & ริ & ñ & 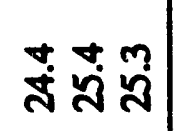 & ạ & $\infty \pi m$ \\
\hline & & క్రి & ñ & $\begin{array}{l}\sim \\
N\end{array}$ & 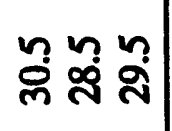 & \& \\
\hline & \multirow{4}{*}{ 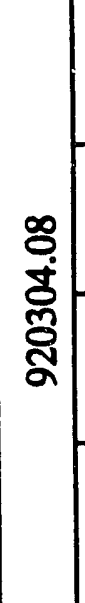 } & ปั & స్ & 車 & ซึ่ & $\stackrel{\infty}{n}$ 쇼 \\
\hline & & స్రి & 웅형 & 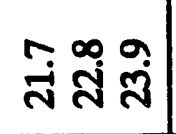 & ํํำ & ๓n 유 \\
\hline & & 今̊ & స్ల 권 & ચં & 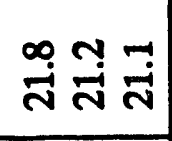 & タ่ํํํ \\
\hline & & $\begin{array}{l}50 \\
8 \\
8\end{array}$ & 市弪 & సं & 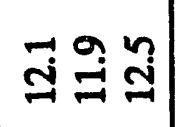 & 트용 \\
\hline & \multirow{5}{*}{ 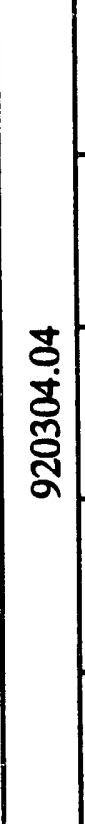 } & 8 & 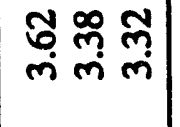 & 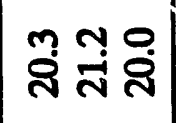 & 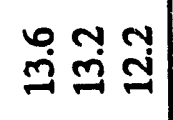 & న̊ \\
\hline & & 气̊ & 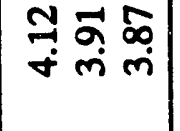 & 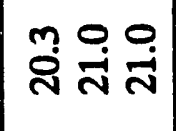 & $\underset{\infty}{\infty} \underset{\infty}{\infty}$ & ஜ요 \\
\hline & & $\begin{array}{l}80 \\
0 \\
n\end{array}$ & $\begin{array}{ccc}8 & \infty & \infty \\
\sim & \infty & \infty \\
\dot{+} & +\end{array}$ & m ষ্ণ & F & ఫે ఫ్ ఫ్ \\
\hline & & ลั & 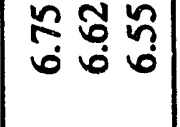 & ڤ̊ & $\stackrel{n}{\sim} \underset{-}{\sigma}$ & $\mathbb{1} \underset{-10}{0}$ \\
\hline & & 8 & 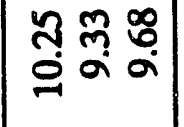 & 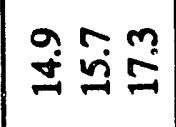 & 꿍 뚱 & ช్ำ ปั \\
\hline & $\begin{array}{l}\dot{0} \\
z \\
\dot{z} \\
\dot{z}\end{array}$ & $\underset{7}{ \pm 1}$ & 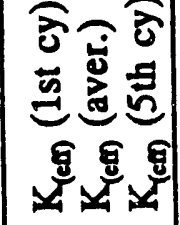 & 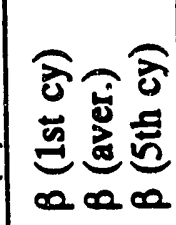 & 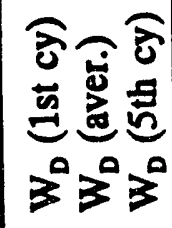 & 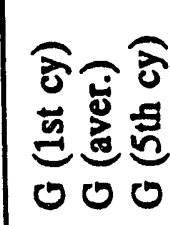 \\
\hline
\end{tabular}

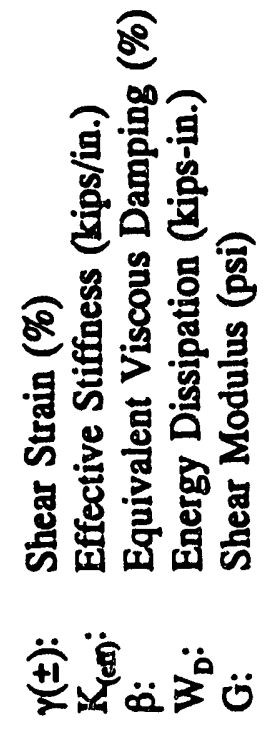




\begin{tabular}{|c|c|c|c|c|c|c|}
\hline \multirow{14}{*}{ 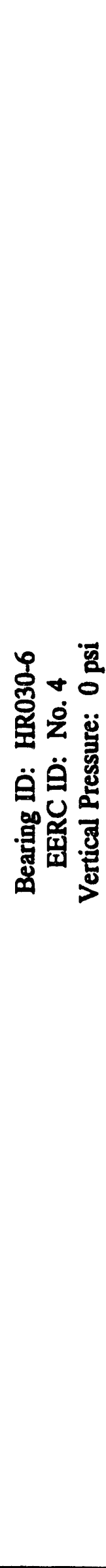 } & \multirow{4}{*}{ ్ㅜㅇ } & $\begin{array}{l}82 \\
8 \\
n\end{array}$ & S & 뚱 & $\begin{array}{lll}n & 0 & 0 \\
\gamma & 8 & 8\end{array}$ & nூ $q$ q \\
\hline & & ళ్ & 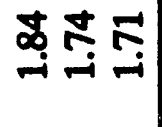 & man & 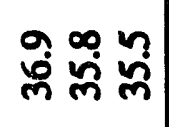 & 85 \\
\hline & & ริ & 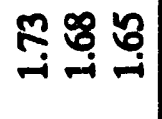 & 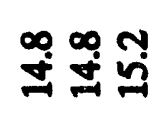 & 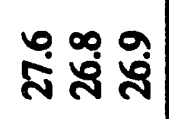 & 85 \\
\hline & & ళ్రి & 酉芛 & 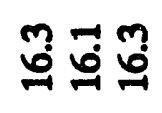 & 㝏 & $y$ \\
\hline & \multirow{4}{*}{ స్ } & $\begin{array}{l}5 \\
2\end{array}$ & ్ㅗ슉 & $\begin{array}{l}n \\
m \neq \\
\sim\end{array}$ & 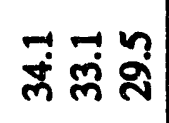 & 族 \\
\hline & & ర్ల & 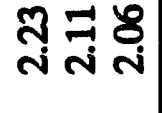 & ஸٌ & 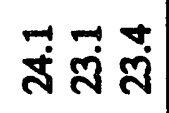 & ถั่ \\
\hline & & $\begin{array}{l}82 \\
8 \\
5\end{array}$ & 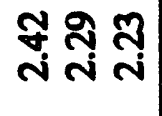 & 부워 & 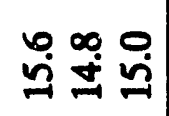 & $\overline{0}$ 舟 \\
\hline & & $8^{8}$ & $\begin{array}{l}9 \\
\infty \\
i \\
i \\
\text { N }\end{array}$ & $\begin{array}{l}n \\
0 \\
0\end{array}$ & œ & $M R R$ \\
\hline & \multirow{5}{*}{ స్ } & $8_{0}^{8}$ & 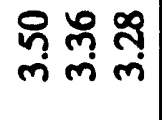 & 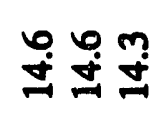 & オั & வ $\infty$ \\
\hline & & $\stackrel{50}{\swarrow 2}$ & 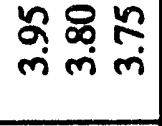 & 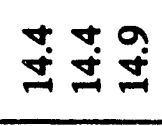 & $\begin{array}{l}\infty \text { ọ } \\
\text { rivi }\end{array}$ & 85 ă \\
\hline & & 윰 & $\underset{\dot{\sigma} \leftarrow \dot{q}}{\infty}$ & 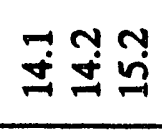 & m & $\stackrel{a}{\exists} \Xi$ \\
\hline & & ฟั & 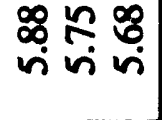 & $\underset{+}{+\infty} \underset{-\infty}{\infty}$ & $\stackrel{0}{i} \stackrel{0}{0} \stackrel{\infty}{0}$ & $\underset{-1}{g} \underset{-1}{t}$ \\
\hline & & 8 & 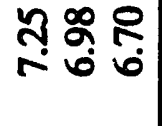 & $\stackrel{a}{m} \underset{m}{\dot{q}}$ & ํㅗㅇ 뜽 & \$툐 톡 \\
\hline & $\begin{array}{l}\dot{0} \\
z \\
0\end{array}$ & $\underset{2}{+11}$ & 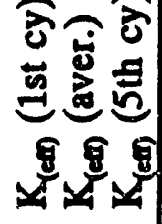 & 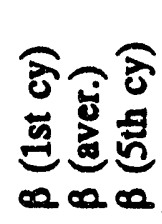 & 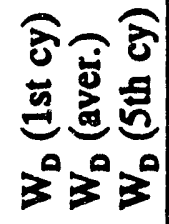 & 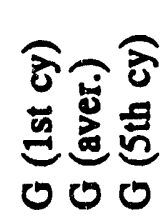 \\
\hline
\end{tabular}

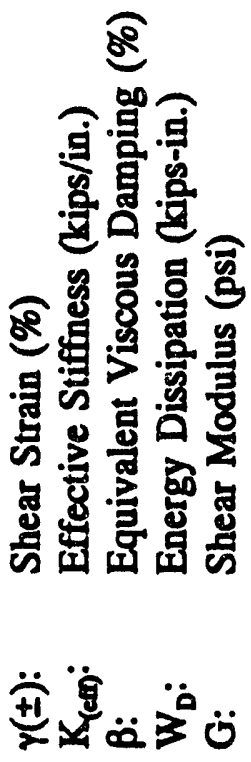




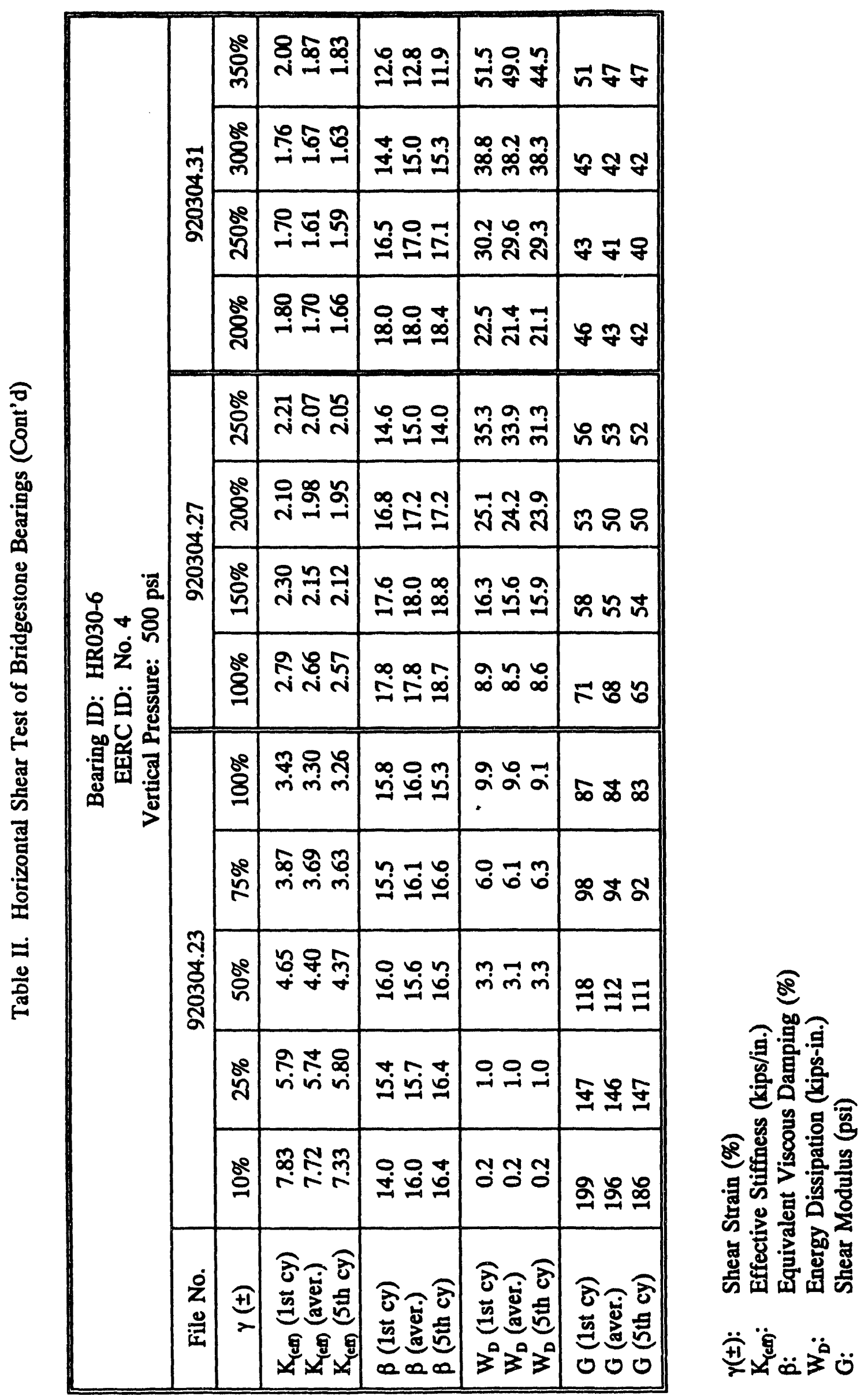


32

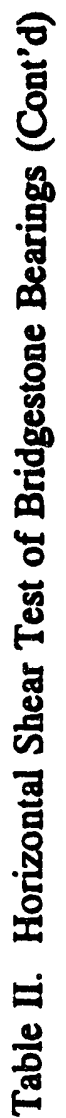

\begin{tabular}{|c|c|c|c|c|c|c|}
\hline & & 总 & רุ & 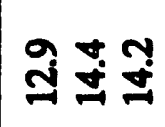 & ํㅜㅇ & $8 n$ 五 \\
\hline & ב̊: & $\sum^{8 R}$ & $\begin{array}{l}9 \pi \delta \\
\text { Nㅜㄴ }\end{array}$ & 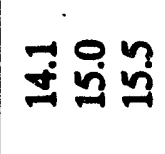 & ฟิ่ & ตุก กี \\
\hline & ร్ & ถึ & 궁 \& & $\underset{0}{0} \stackrel{0}{\sim}$ & 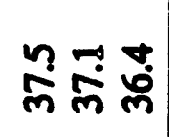 & ヴ \\
\hline & & ஜి & 요 & 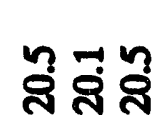 & هั & 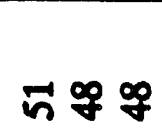 \\
\hline & & $\begin{array}{l}80 \\
\text { ฟิ }\end{array}$ & $\begin{array}{l}\infty \\
\text { ஸ } \\
\sim\end{array}$ & 불ำ & 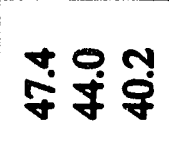 & $\approx 8$ 至 \\
\hline & ম゙્ & ళ్లి & 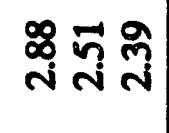 & $\begin{array}{l}0 \\
0 \\
0\end{array}$ & 迎 $\frac{m}{m}$ & 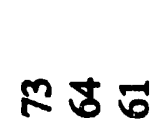 \\
\hline 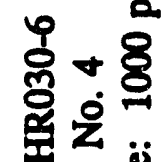 & ริ & है & ํㅜㅇ & Nㅗㅁ & 웧 శீ & \& $\mathbb{2}$ \\
\hline 面是灵 & & 8 & 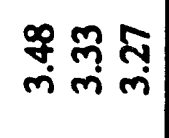 & $\underset{+\infty}{\infty} \underset{+}{\infty}$ & ๓울엉 & $\infty \varnothing$ \\
\hline$\stackrel{2}{\nu}$ & & $\mathscr{8}^{8}$ & 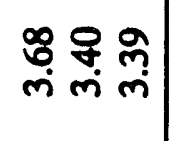 & 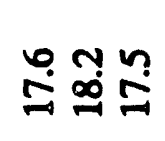 & 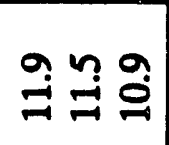 & ম $\approx \&$ \\
\hline & & 疍 & 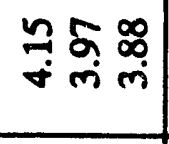 & $\begin{array}{c}0 \\
\infty \\
\infty\end{array}$ & $\stackrel{\infty}{\sim} \stackrel{m}{r}$ & 응요 웅 \\
\hline & 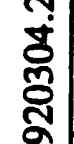 & 50 & 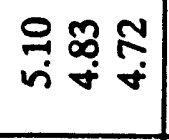 & $\underset{\infty}{0} \underset{-\infty}{\infty}$ & 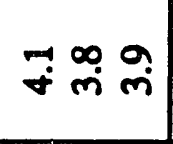 & 육 ㄱ్ㄱㄱㄱ \\
\hline & & $\begin{array}{l}80 \\
7\end{array}$ & \begin{tabular}{lll}
6 & \multirow{4}{*}{} & $q$ \\
0 & 0 & 0
\end{tabular} & $\stackrel{0}{0} \underset{\sim}{\infty}$ & $\dddot{m} \dddot{m} \dddot{m}$ & 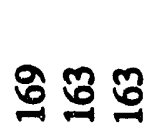 \\
\hline & & $\stackrel{8 R}{\circ}$ & $\begin{array}{lll}R & q & \infty \\
\infty & \infty & \infty\end{array} \mid$ & 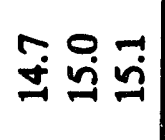 & 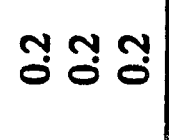 & 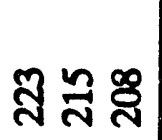 \\
\hline & $\begin{array}{l}\dot{0} \\
\dot{z} \\
\dot{0}\end{array}$ & $\underset{2}{ \pm 1}$ & 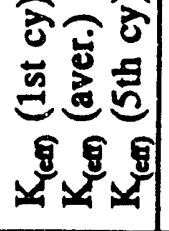 & 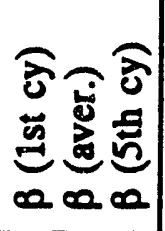 & 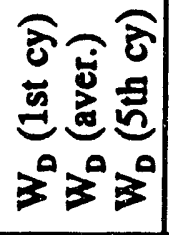 & 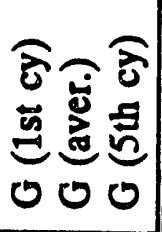 \\
\hline
\end{tabular}

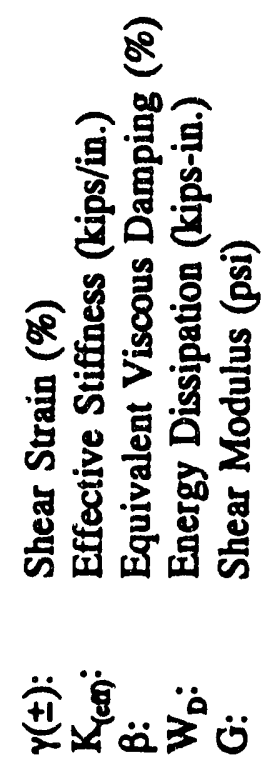




\begin{tabular}{|c|c|c|c|c|c|c|}
\hline \multirow{14}{*}{ 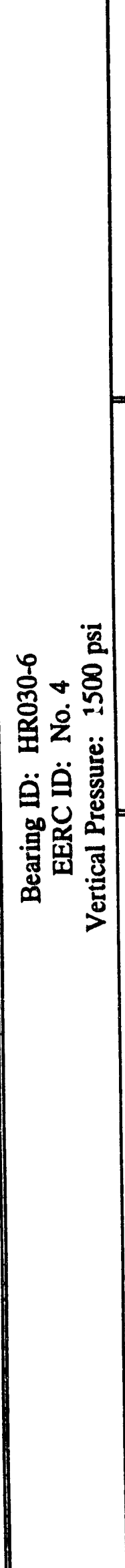 } & \multirow{4}{*}{ 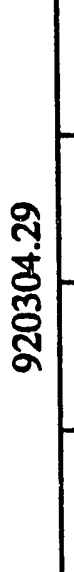 } & $\frac{8}{8}$ & 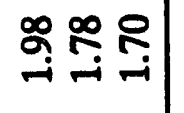 & $\begin{array}{l}0 \\
0 \\
0 \\
\infty\end{array}$ & 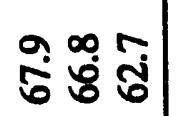 & คำ \\
\hline & & 8̊ & 중 & ชู่ กุ & $\begin{array}{l}a \\
\text { กี } \\
\end{array}$ & 丈 8 \\
\hline & & $\begin{array}{l}5 \\
\text { ฟิ }\end{array}$ & 8 후 & 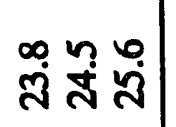 & ò & $\forall \infty$ \\
\hline & & శ్రి & ڤై & 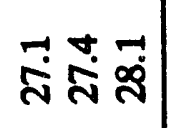 & 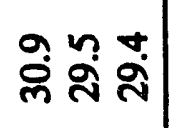 & 霛 \\
\hline & & $\begin{array}{l}50 \\
\text { ำ }\end{array}$ & 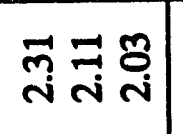 & ơ & 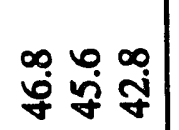 & タั๋ \\
\hline & กิ & ర్లి & 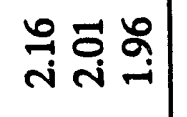 & 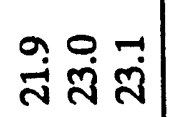 & 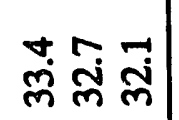 & n๊ \\
\hline & గ్ల్ & $\begin{array}{l}5 \\
8 \\
2\end{array}$ & $\stackrel{m}{\stackrel{m}{\sim} \underset{\sim}{\sim}} \underset{\sim}{\vec{N}}$ & 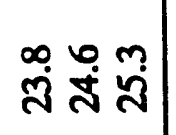 & ஸ̃ & タnぇั \\
\hline & & ర్రి & $\begin{array}{lll} & 0 & \infty \\
\infty & \mathbb{R} & 0 \\
\sim & \sim & \sim\end{array}$ & 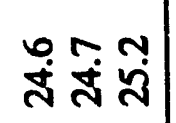 & 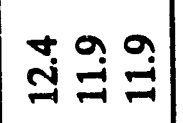 & 둥 \\
\hline & & $\begin{array}{l}8 \\
8 \\
8\end{array}$ & $\begin{array}{lll}\infty & \infty & m \\
\sim & m & m \\
m & m & m\end{array}$ & 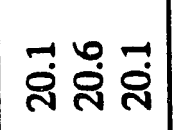 & 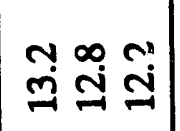 & 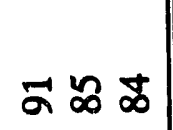 \\
\hline & & $\stackrel{s}{n}$ & \begin{tabular}{lcc} 
& $m$ & 0 \\
\hdashline & $\infty$ & $\infty$ \\
$\dot{\forall}$ & $m$ & $m$
\end{tabular} & 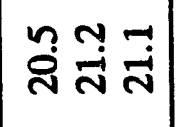 & $\underset{\infty}{+\infty} \underset{\infty}{\forall}$ & 옹 ล \\
\hline & 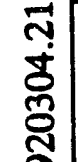 & $\begin{array}{l}8 \\
8 \\
0\end{array}$ & 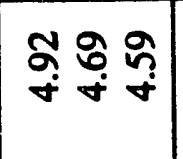 & 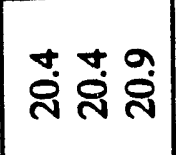 & 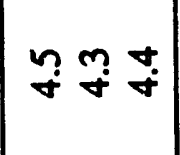 & 글 $\underset{二}{=}$ \\
\hline & & จั & 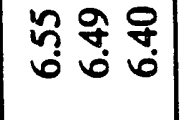 & ma & 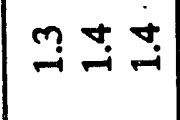 & 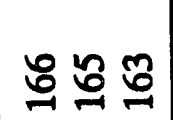 \\
\hline & & 욤 & $\begin{array}{lll}\exists & \varkappa & m \\
a & \infty & \infty\end{array}$ & 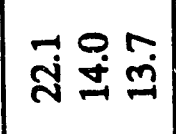 & m 뚱 붕 & ฟิ సิ సิ \\
\hline & 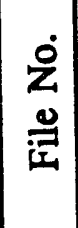 & $\underset{7}{ \pm 1}$ & 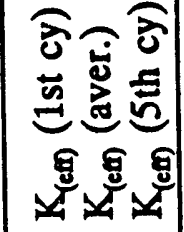 & 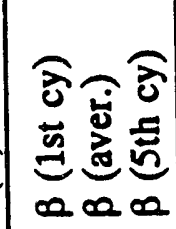 & 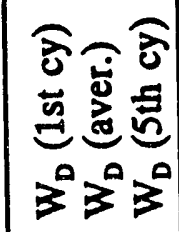 & 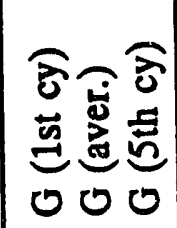 \\
\hline
\end{tabular}

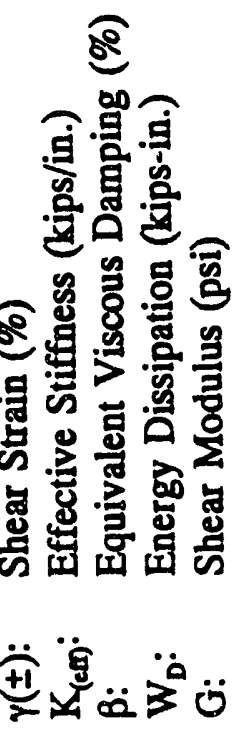


Table III. Vertical Load Test of Bridgestone Bearings

\begin{tabular}{|c|c|c|c|c||}
\hline \multirow{2}{*}{$\begin{array}{c}\text { Pressure } \\
\text { psi }\end{array}$} & \multicolumn{2}{|c|}{$\begin{array}{c}\text { Bearing ID: HR030-2 } \\
\text { EERC ID: } \text { No. 1 }\end{array}$} & \multicolumn{2}{c|}{$\begin{array}{c}\text { Bearing ID: HI.030-3 } \\
\text { EERC ID: No. 2 }\end{array}$} \\
\cline { 2 - 5 } & Filename & $\begin{array}{c}\mathrm{K}_{\text {off }} \\
\text { Kips-in. }\end{array}$ & Filename & $\begin{array}{c}\mathrm{K}_{\text {eff }} \\
\text { Kips-in. }\end{array}$ \\
\hline 500 & 920225.05 & 5387 & 920303.02 & 6926 \\
\hline 1000 & 920225.03 & 7860 & 920303.03 & 9223 \\
\hline 1500 & 920225.04 & 9075 & 920303.14 & 10643 \\
\hline
\end{tabular}

\begin{tabular}{|c|c|c|c|c||}
\hline \multirow{2}{*}{$\begin{array}{c}\text { Pressure } \\
\text { psi }\end{array}$} & \multicolumn{2}{|c|}{$\begin{array}{c}\text { Bearing ID: HR030-5 } \\
\text { EERC ID: No. 3 }\end{array}$} & \multicolumn{2}{c|}{$\begin{array}{c}\text { Bearing ID: HR030-6 } \\
\text { EERC ID: No. 4 }\end{array}$} \\
\cline { 2 - 5 } & Filename & $\begin{array}{c}\mathrm{K}_{\text {eff }} \\
\text { Kips-in. }\end{array}$ & Filename & $\begin{array}{c}\mathrm{K}_{\text {eff }} \\
\text { Kips-in. }\end{array}$ \\
\hline 500 & 920303.20 & 6889 & 920304.16 & 5589 \\
\hline 1000 & 920303.21 & 8854 & 920304.17 & 7440 \\
\hline 1500 & 920303.22 & 9769 & 920304.18 & 8721 \\
\hline
\end{tabular}



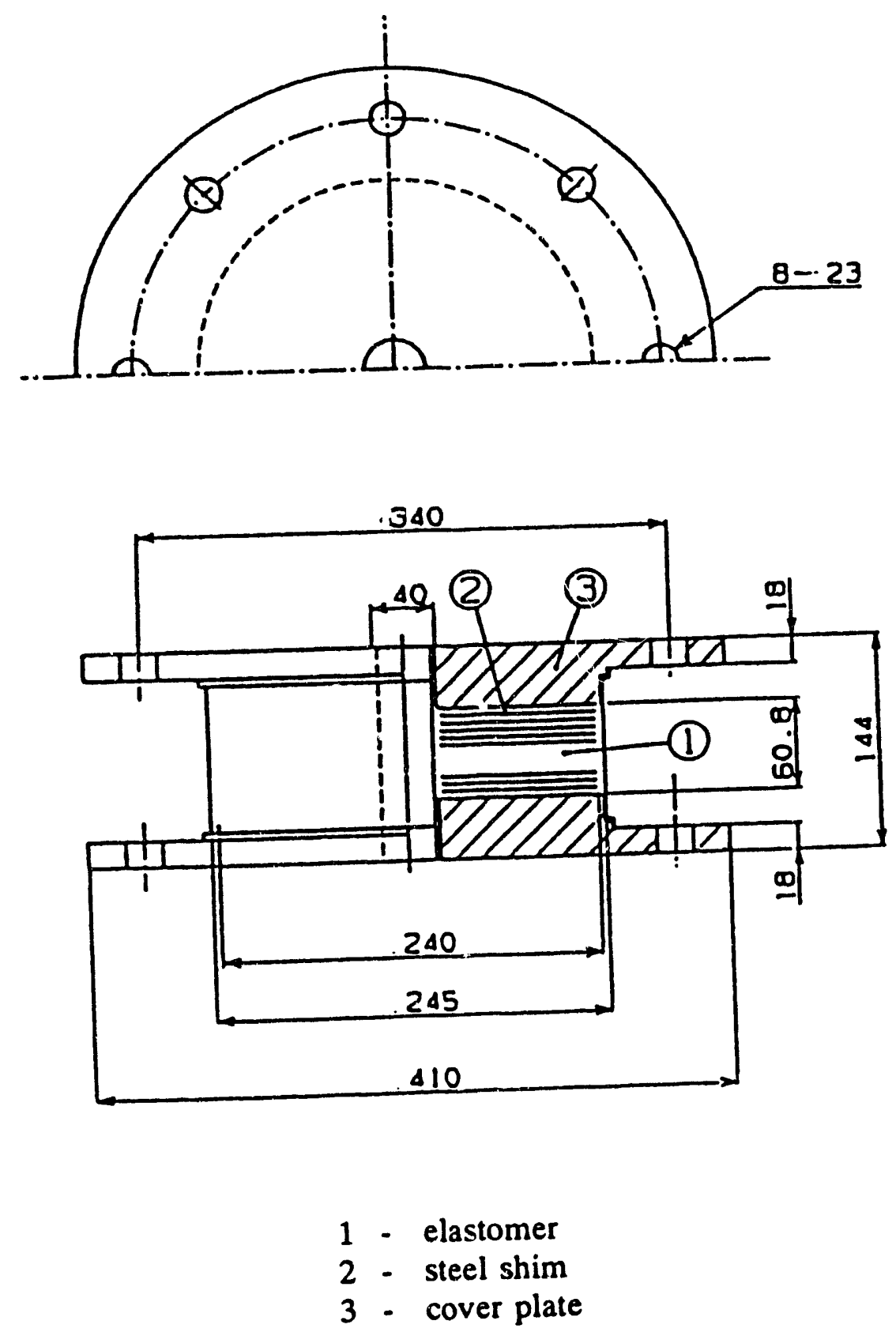

Fig. 1. The Dimensions of the Test Bearings 


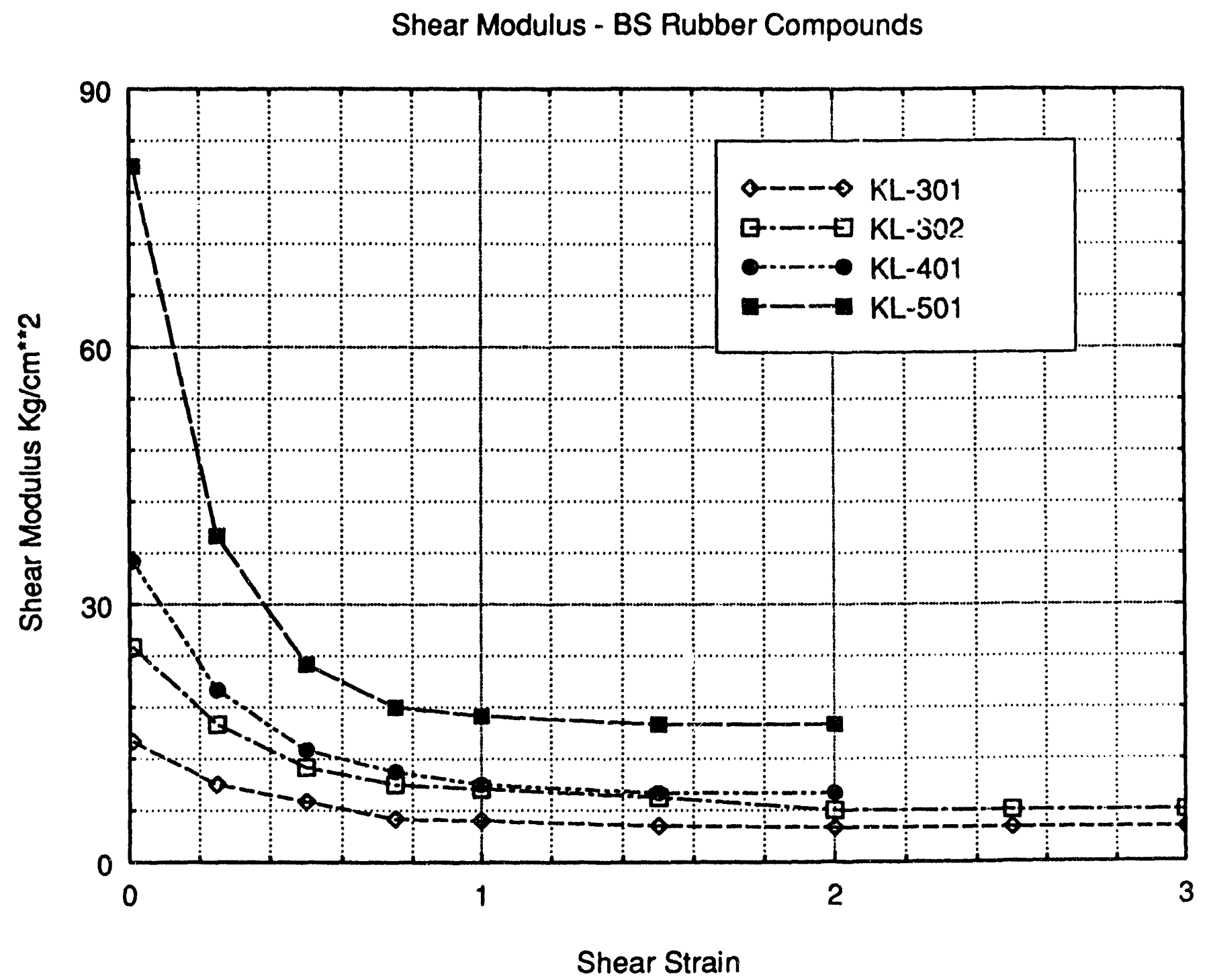

Fig. 2. Shear Modulus as a Function of Shear Sirain of Bridgestone Elastomer Compounds 


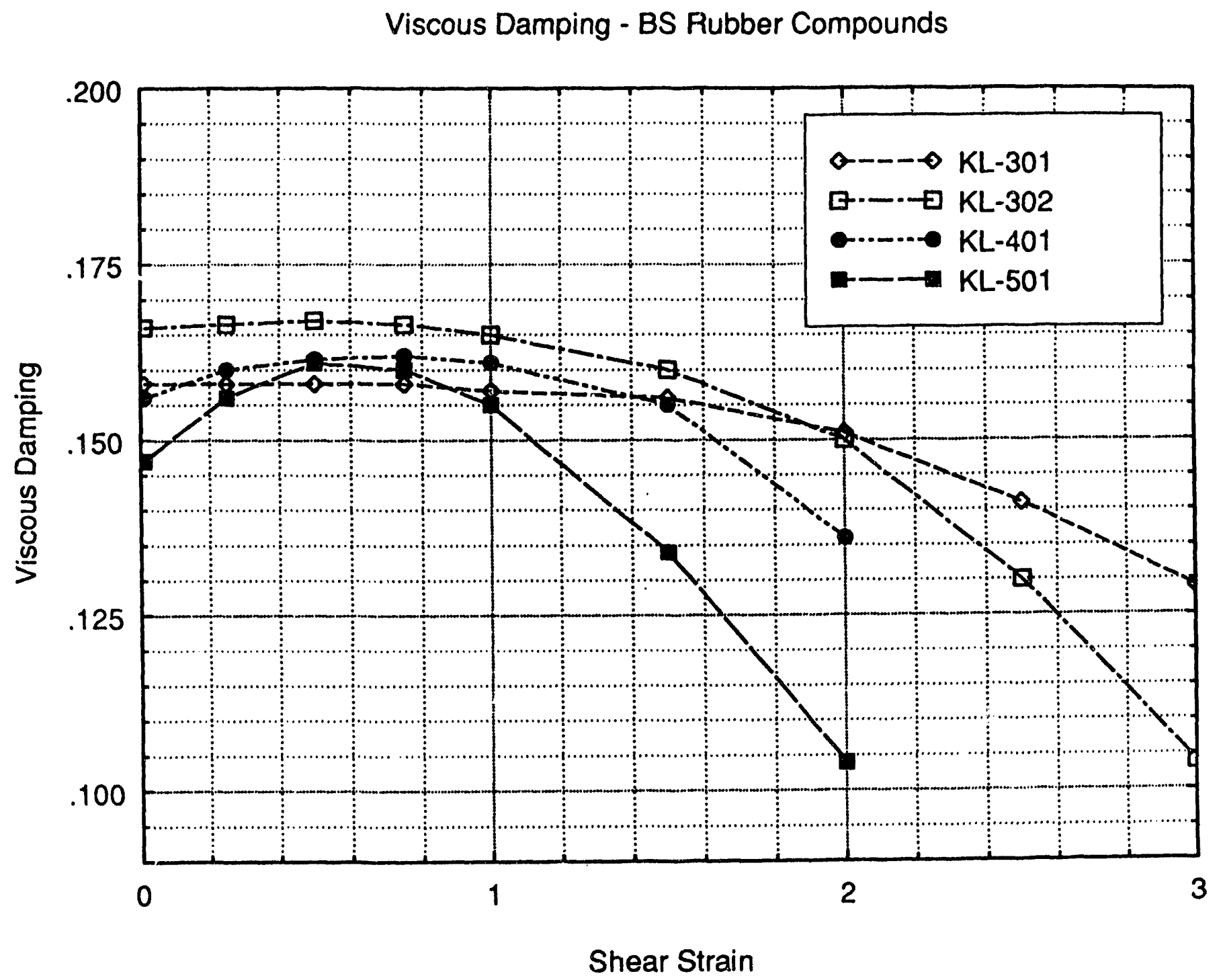

Fig. 3. Viscous Damping as a Function of Shear Strain of Bridgestone Elastomer Compounds 


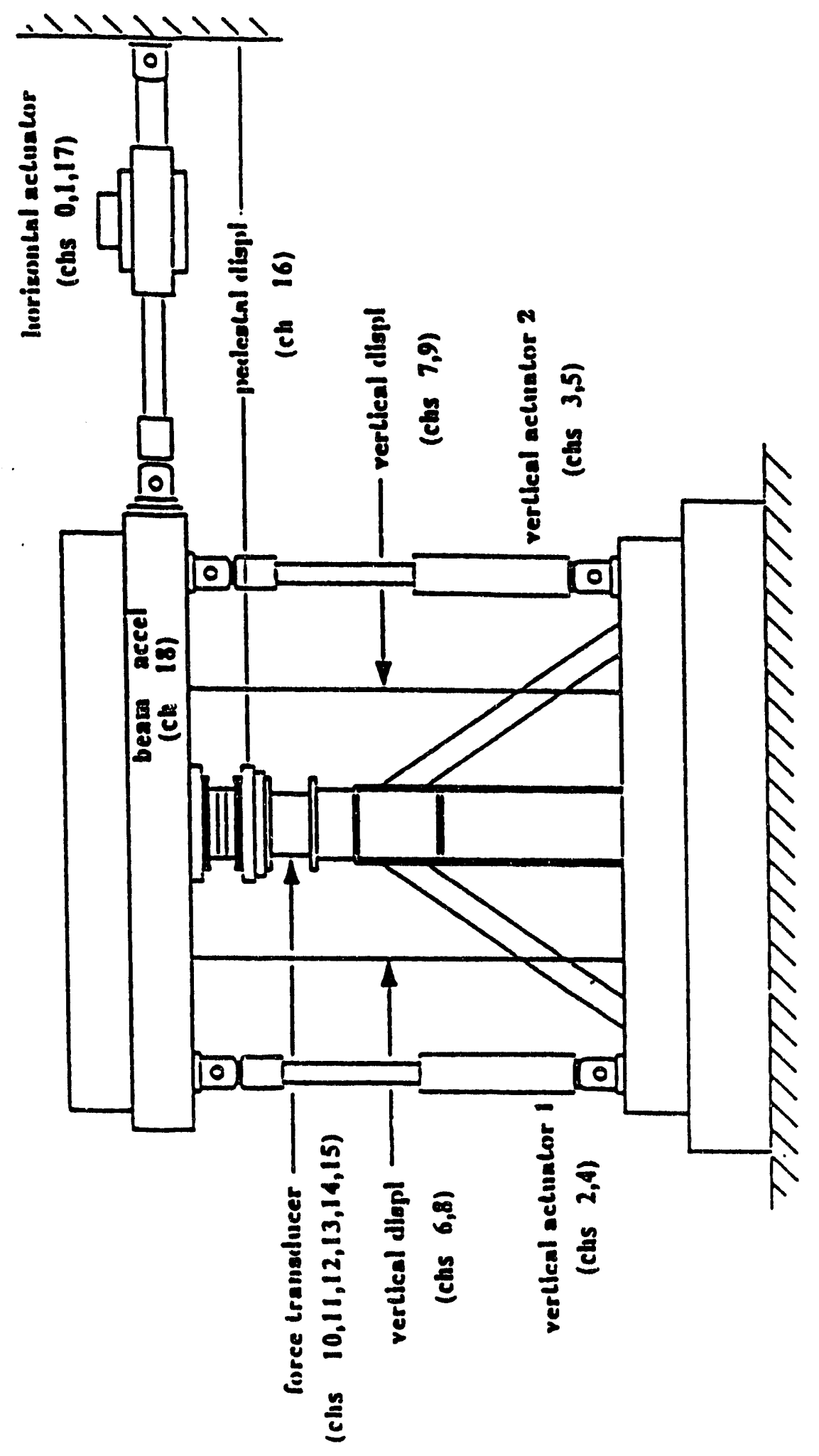

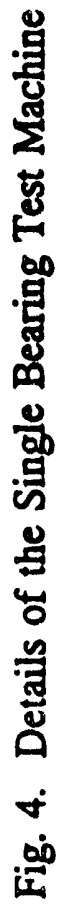




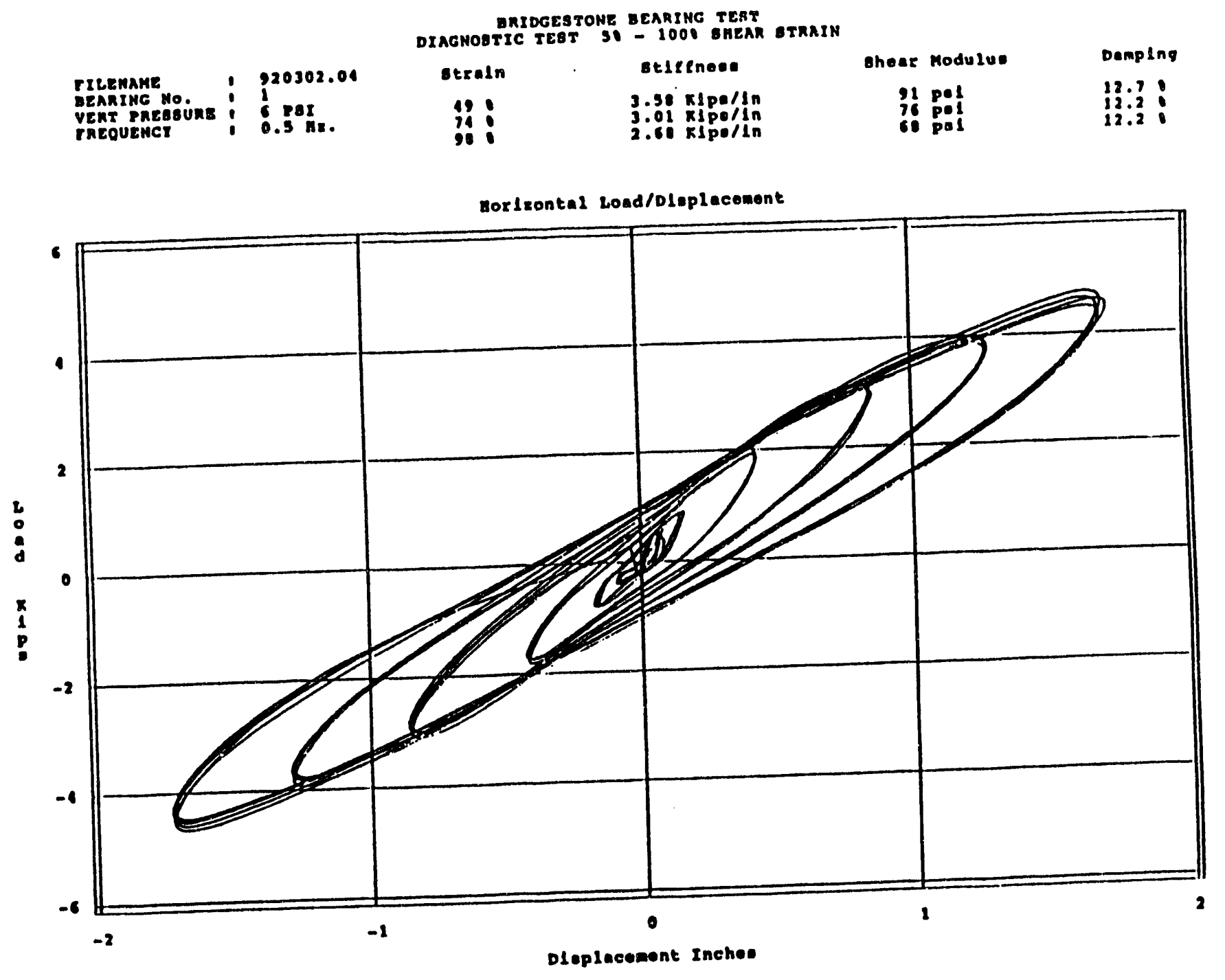

Fig. 5. Force Displacement Plots for Sequence I Tests - Zero Vertical Pressure 


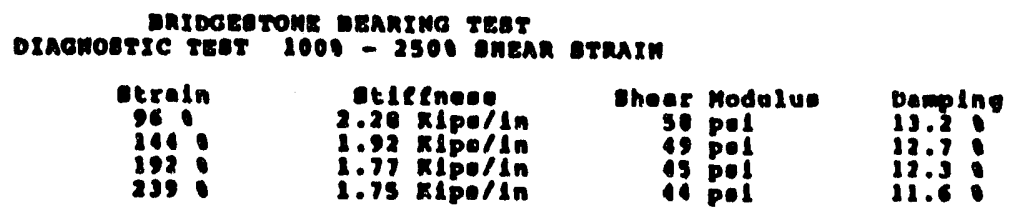

Dorlsontel Load/oloplaoement

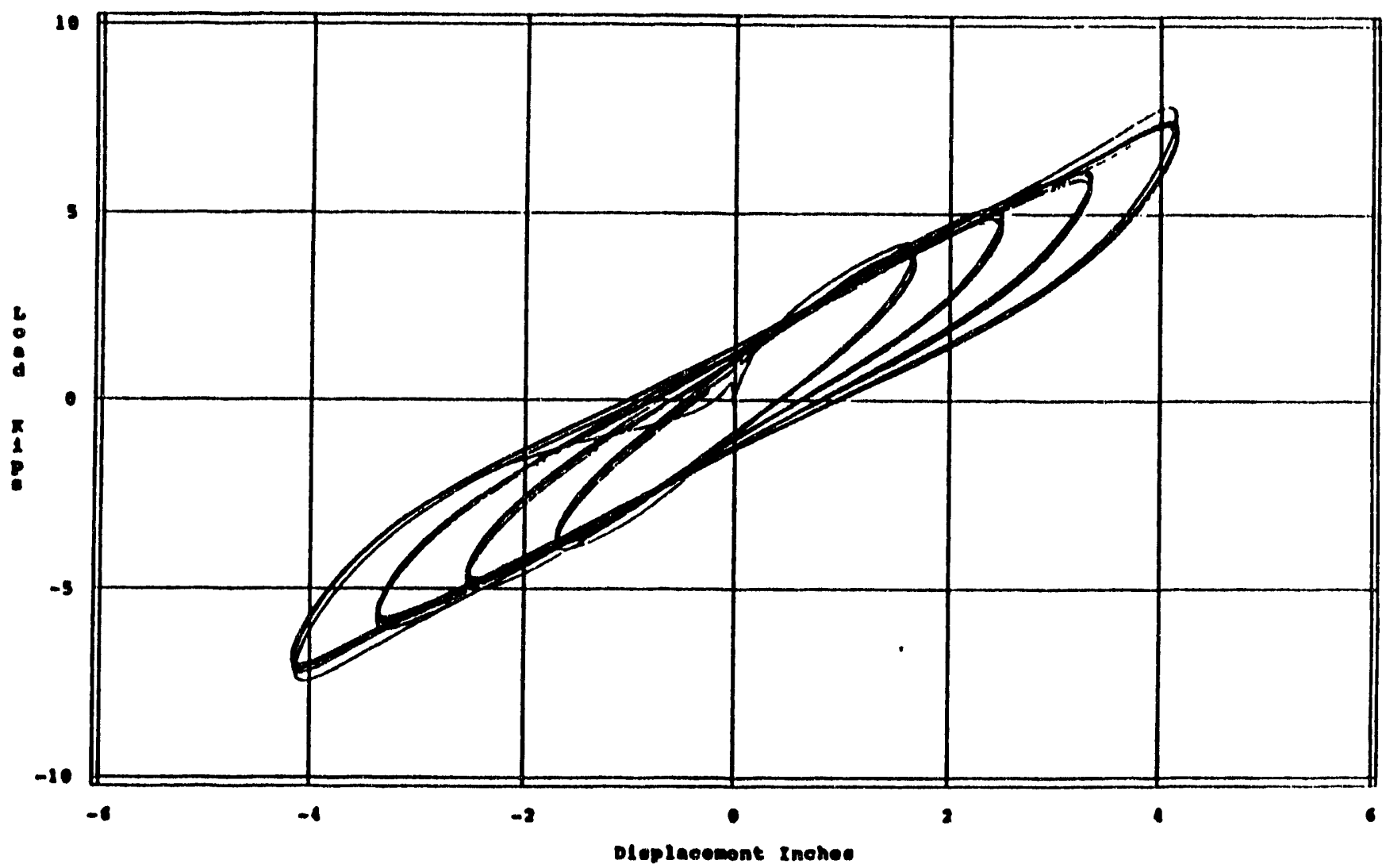

Fig. 6. Force Displacement Plots for Sequence II Tests - Zero Vertical Pressure 


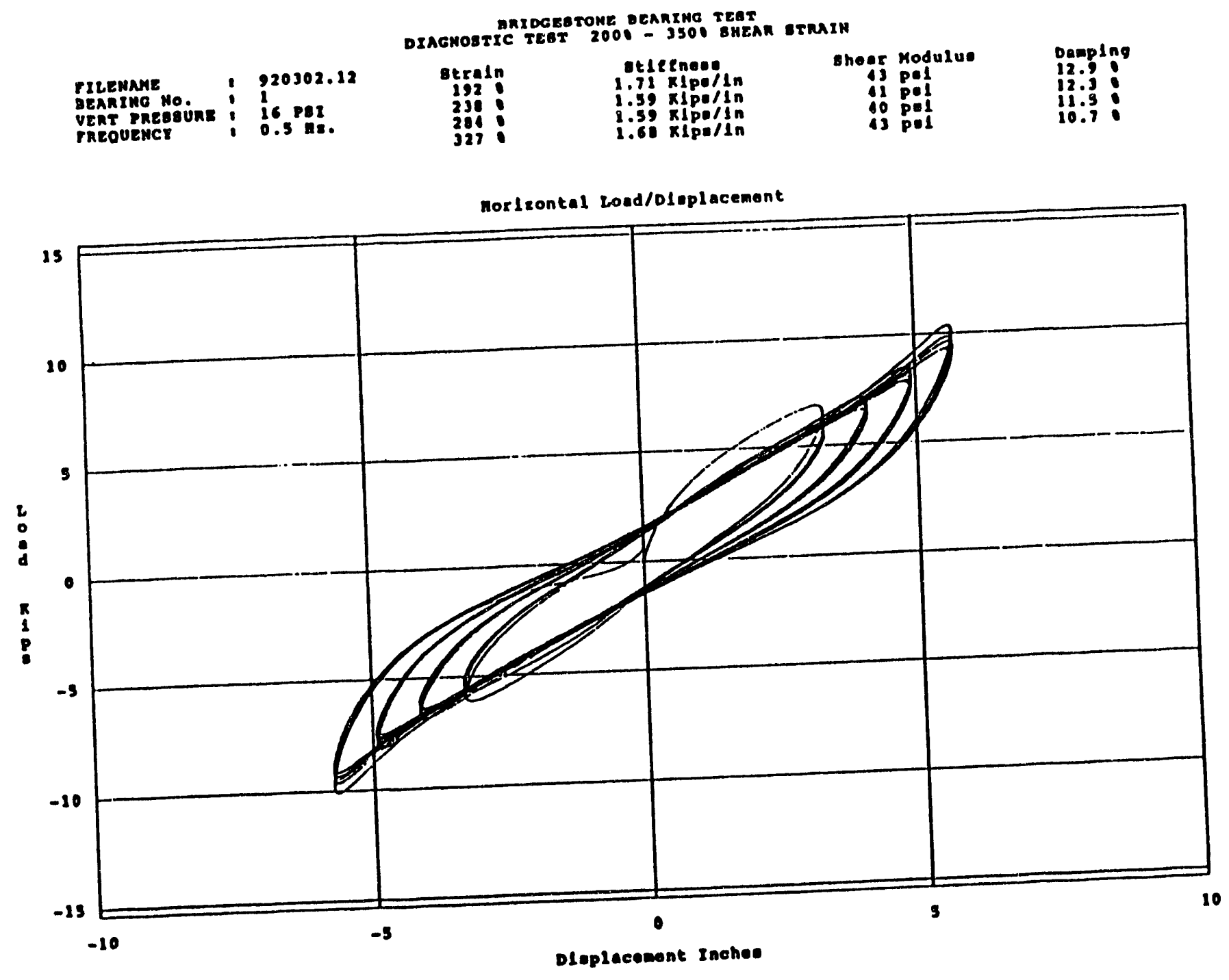

Fig. 7. Force Displacement Plots for Sequence III Tests - Zero Vertical Pressure 


\begin{tabular}{|c|c|c|c|c|c|}
\hline & & Menos & $\begin{array}{l}\text { geaning Trat } \\
\text { - } 1000 \text { Bnean }\end{array}$ & & \\
\hline 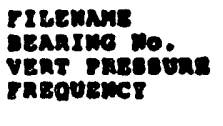 & 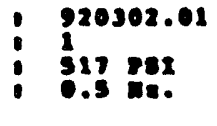 & $\begin{array}{l}\text { Derada } \\
49: \\
70:\end{array}$ & 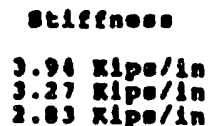 & $\begin{array}{c}\text { ohear Modulue } \\
100 \text { pel } \\
13 \text { pel } \\
72 \text { pol }\end{array}$ & $\begin{array}{l}\text { Demplng } \\
13.6 ! \\
13.6: \\
13.1:\end{array}$ \\
\hline
\end{tabular}

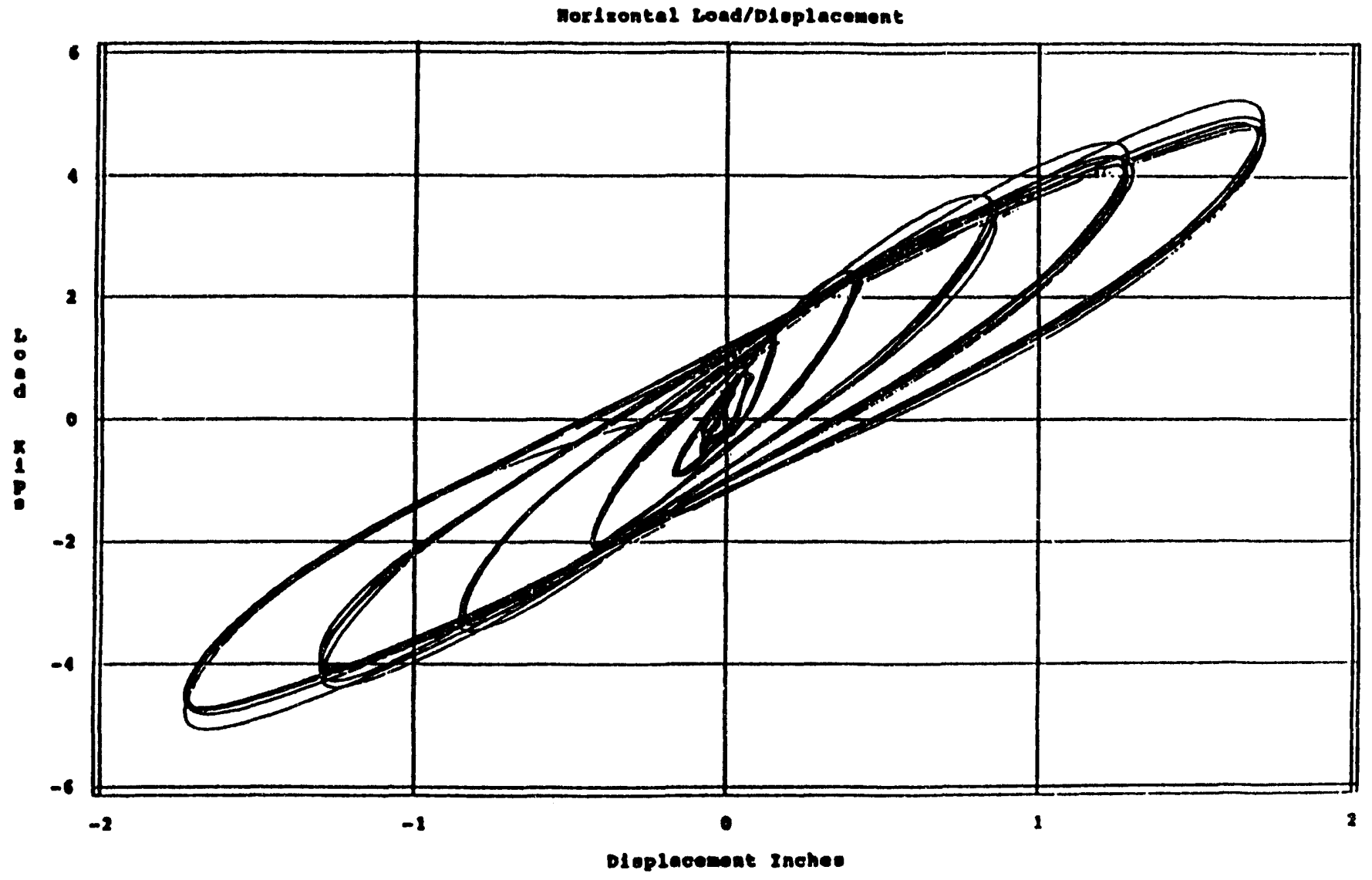

Fig. 8. Force Displacement Plots for Sequence I Tests - 3.45 MPa Vertical Pressure 


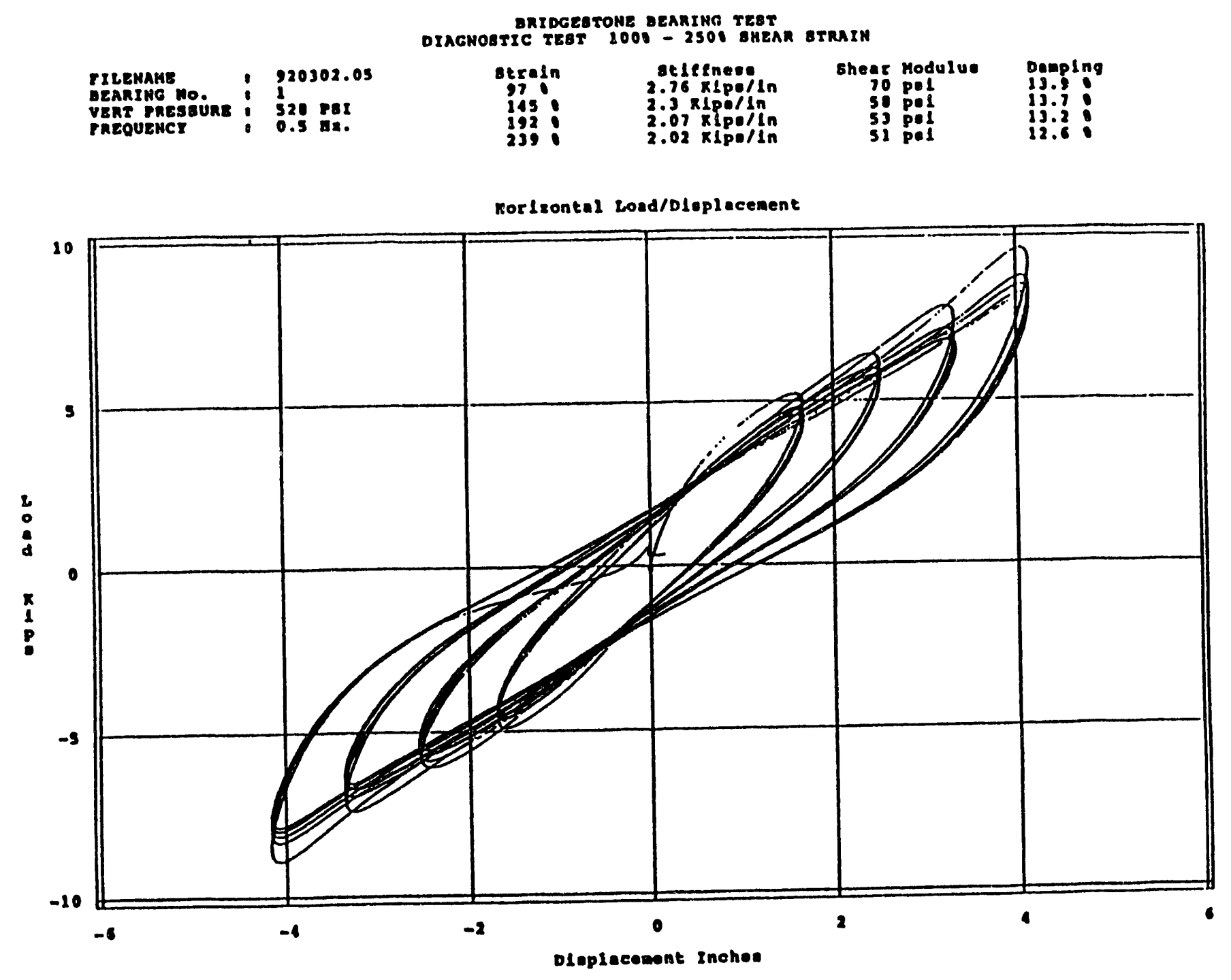

Fig. 9. Force Displacement Plots for Sequence II Tests - 3.45 MPa Vertical Pressure 


\begin{tabular}{|c|c|c|c|c|c|}
\hline 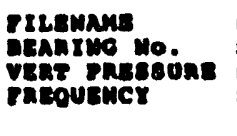 & $\begin{array}{l}920302.09 \\
: 321 \mathrm{per} \\
\text { : }\end{array}$ & $\begin{array}{l}\text { otraln } \\
193: \\
240 \\
204: \\
320:\end{array}$ & 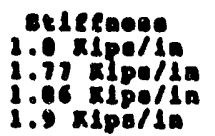 & $\begin{array}{l}\text { Ihear modusu } \\
\text { if pol } \\
\text { is pol } \\
\text { if pol } \\
\text { is pel }\end{array}$ & $\begin{array}{l}\text { Deoping } \\
\text { iJ.8: } \\
\text { iz:s: } \\
\text { ili: }\end{array}$ \\
\hline
\end{tabular}

Gorlwontel zoad/OLOplaoonent

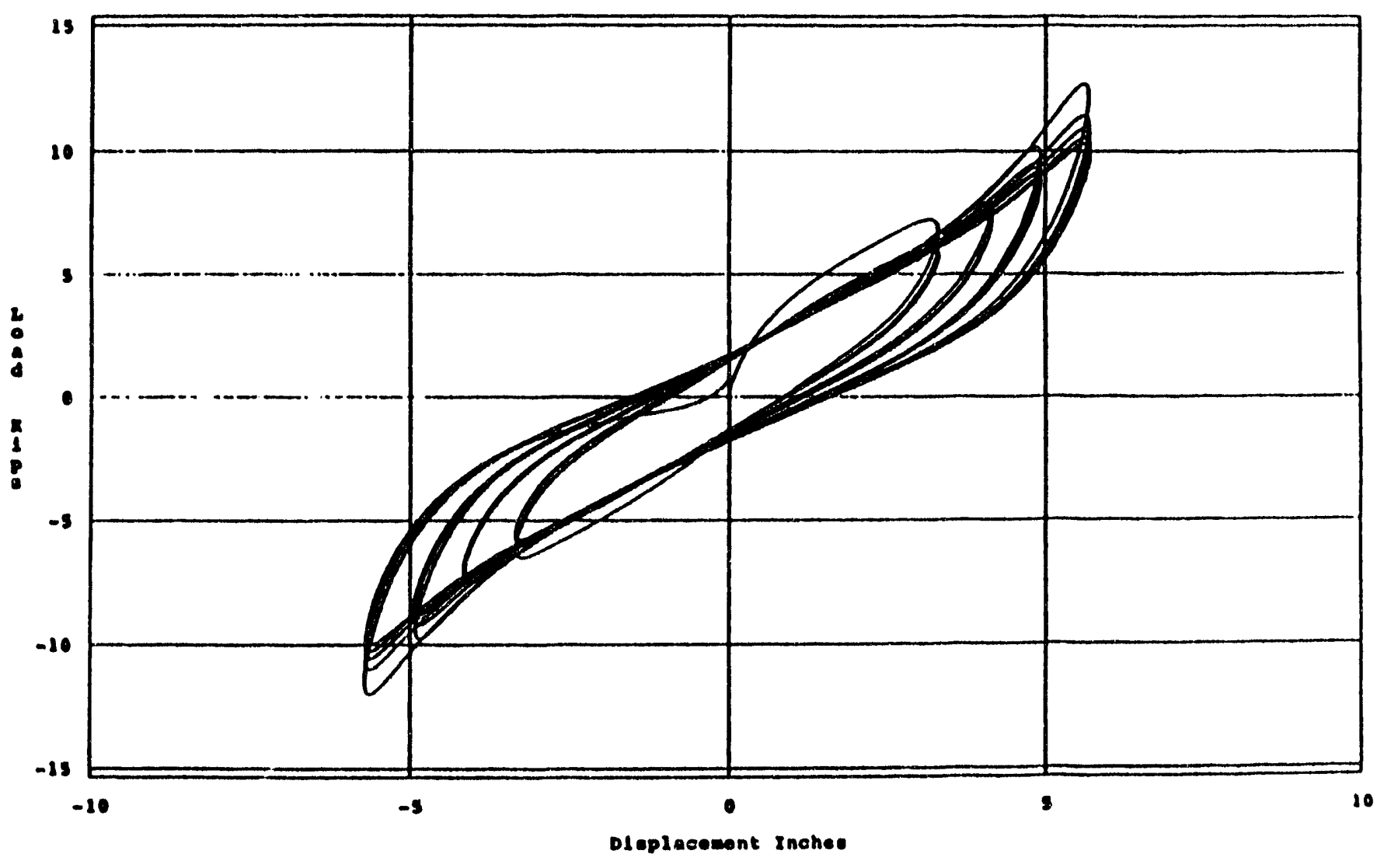

Fig. 10. Force Displacement Plots for Sequence III Tests - 3.45 MPa Vertical Pressure 


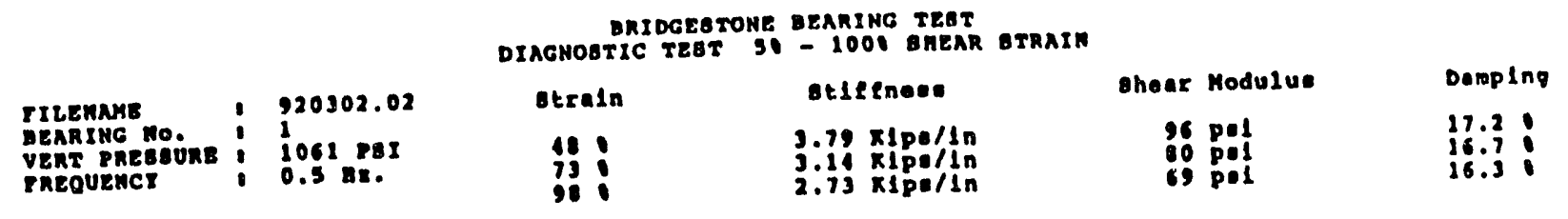

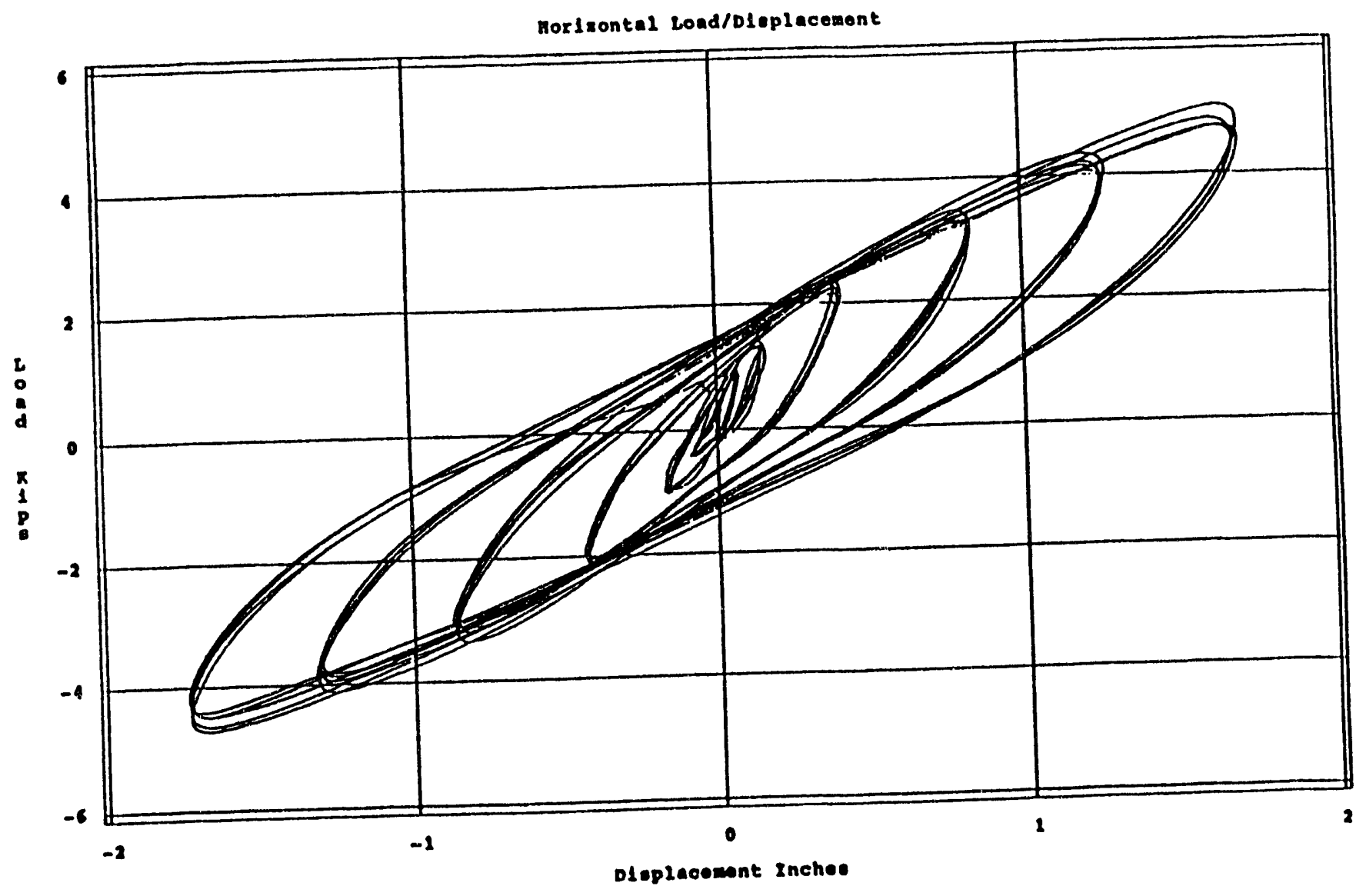

Fig. 11. Force Displacement Plots for Sequence I Tests - 6.90 MPa Vertical Pressure 


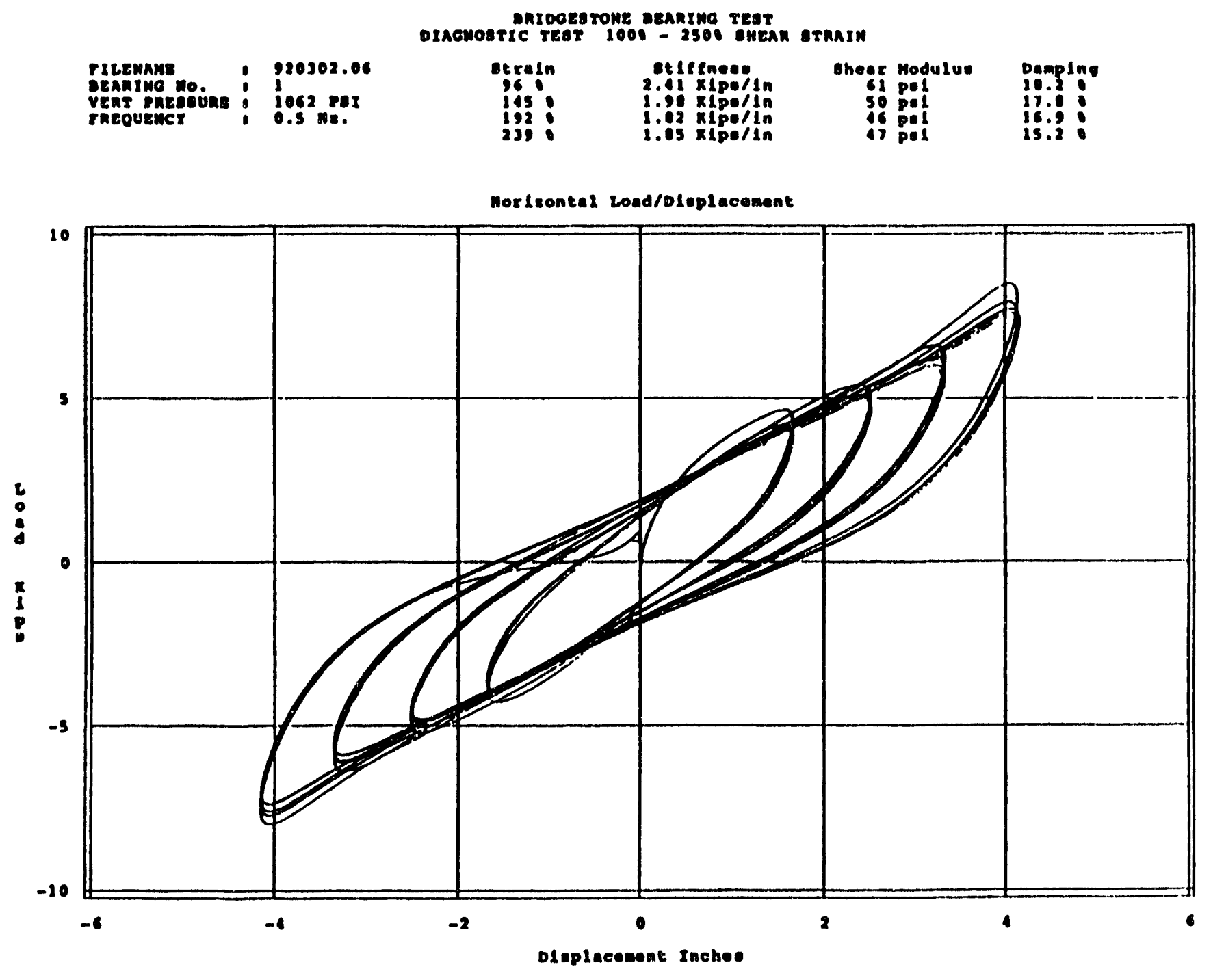

Fig. 12. Force Displacement Plots for Sequence II Tests - 6.90 MPa Vertical Pressure 


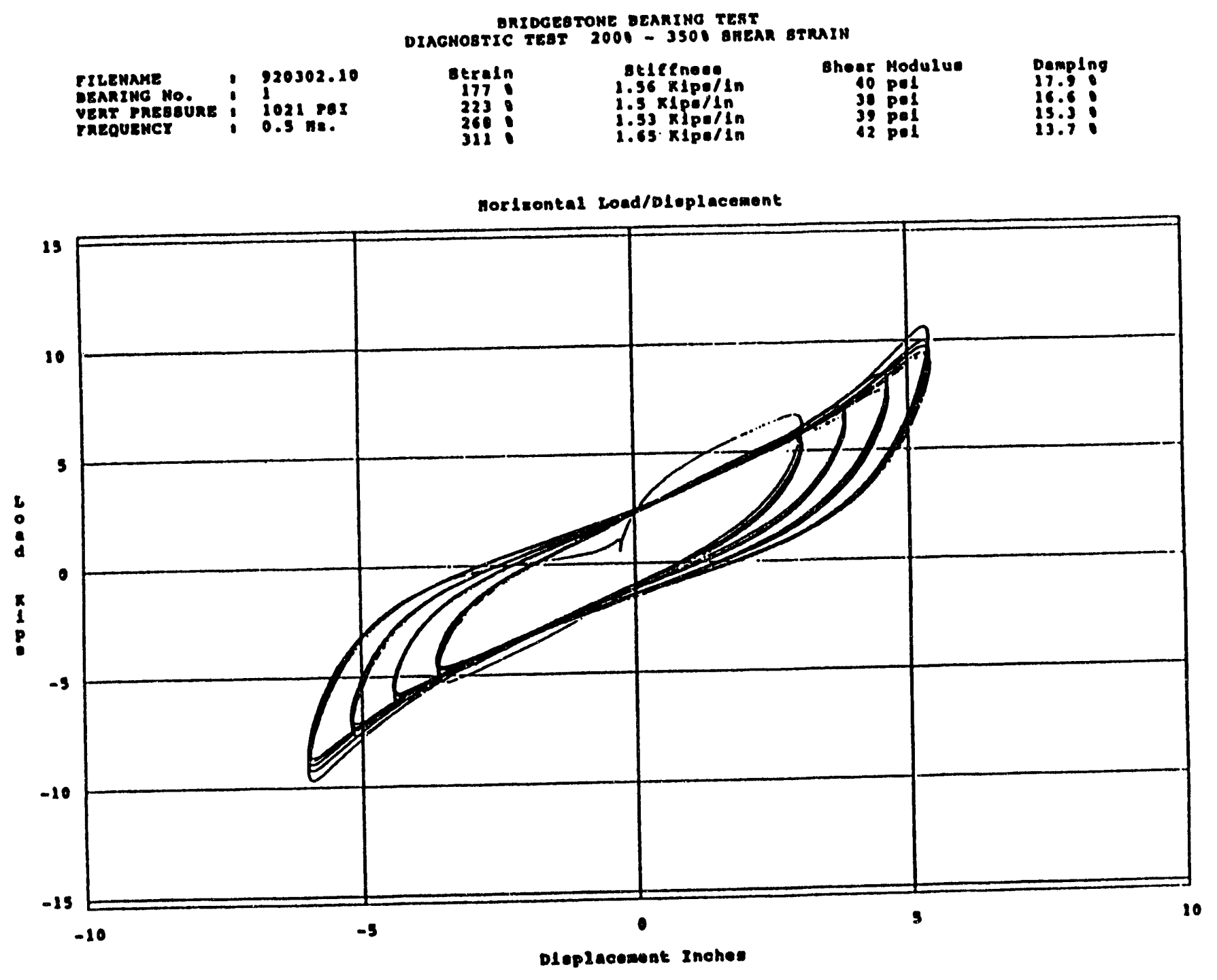

Fig. 13. Force Displacement Plots for Sequence III Tests - 6.90 MPa Vertical Pressure 

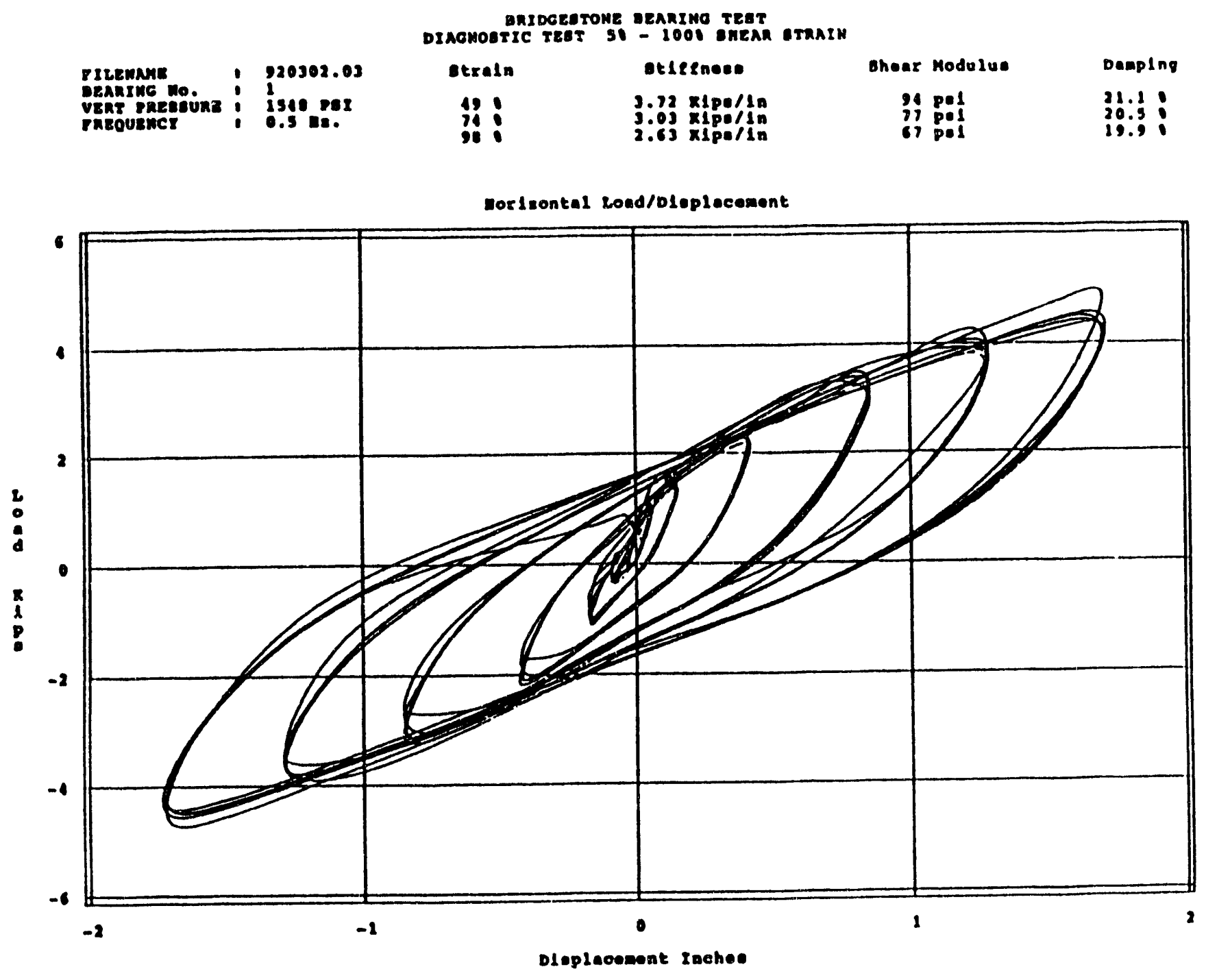

Fig. 14. Force Displacement Plots for Sequence I Tests - 10.35 MPa Vertical Pressure 


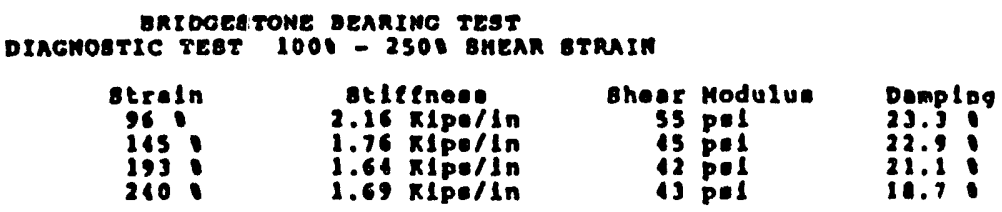

norlrontal Loed/DLplacement

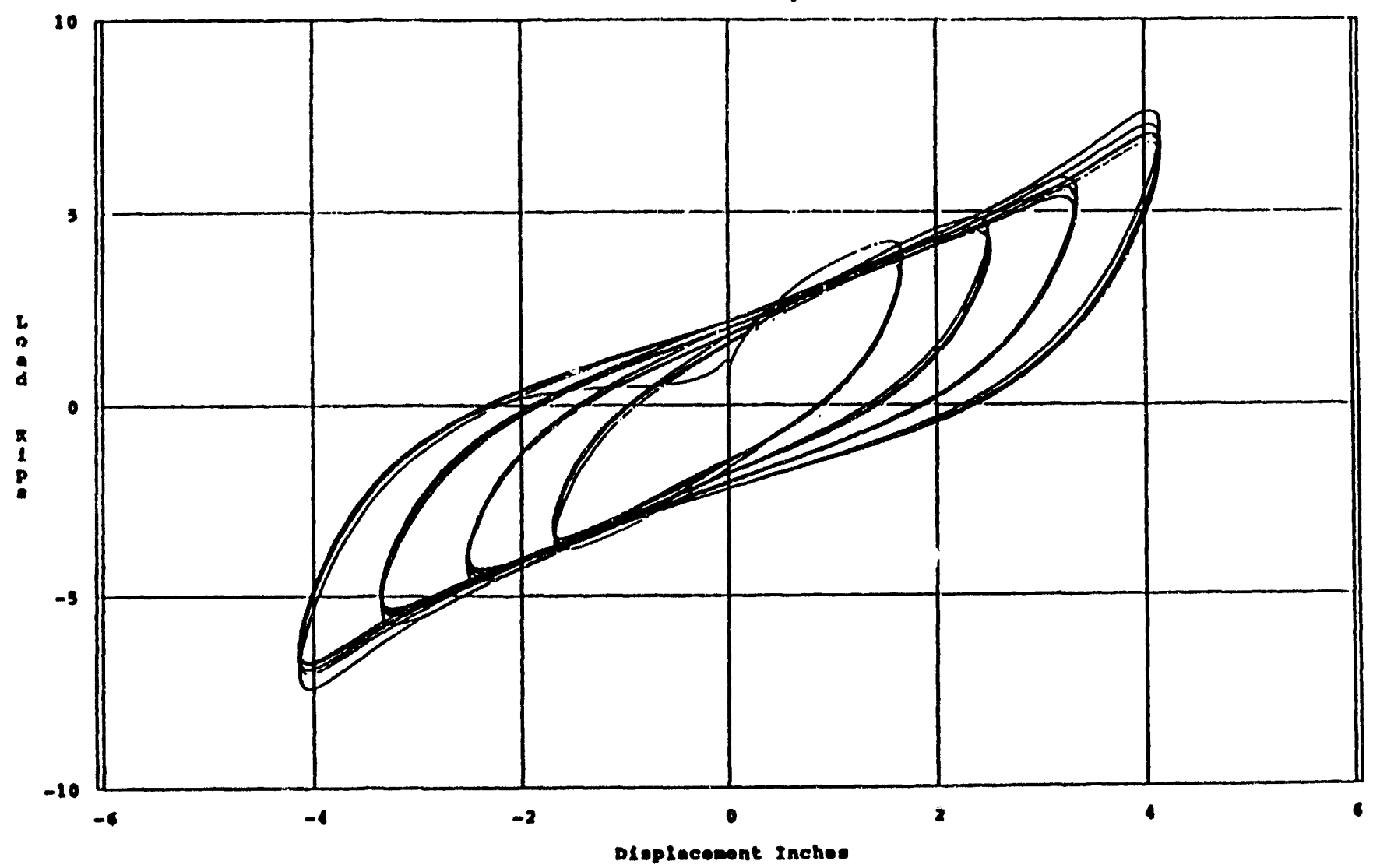

Fig. 15. Force Displacement Plots for Sequence II Tests - 10.35 MPa Vertical Pressure 


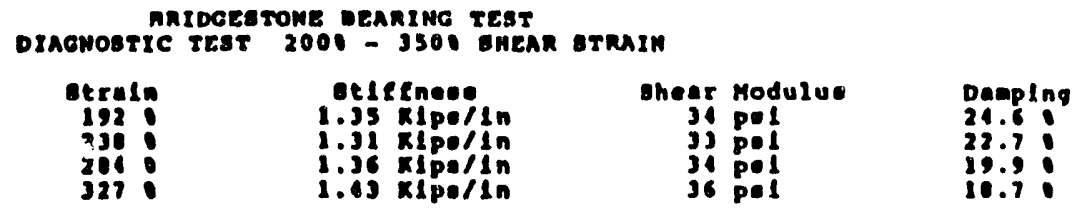

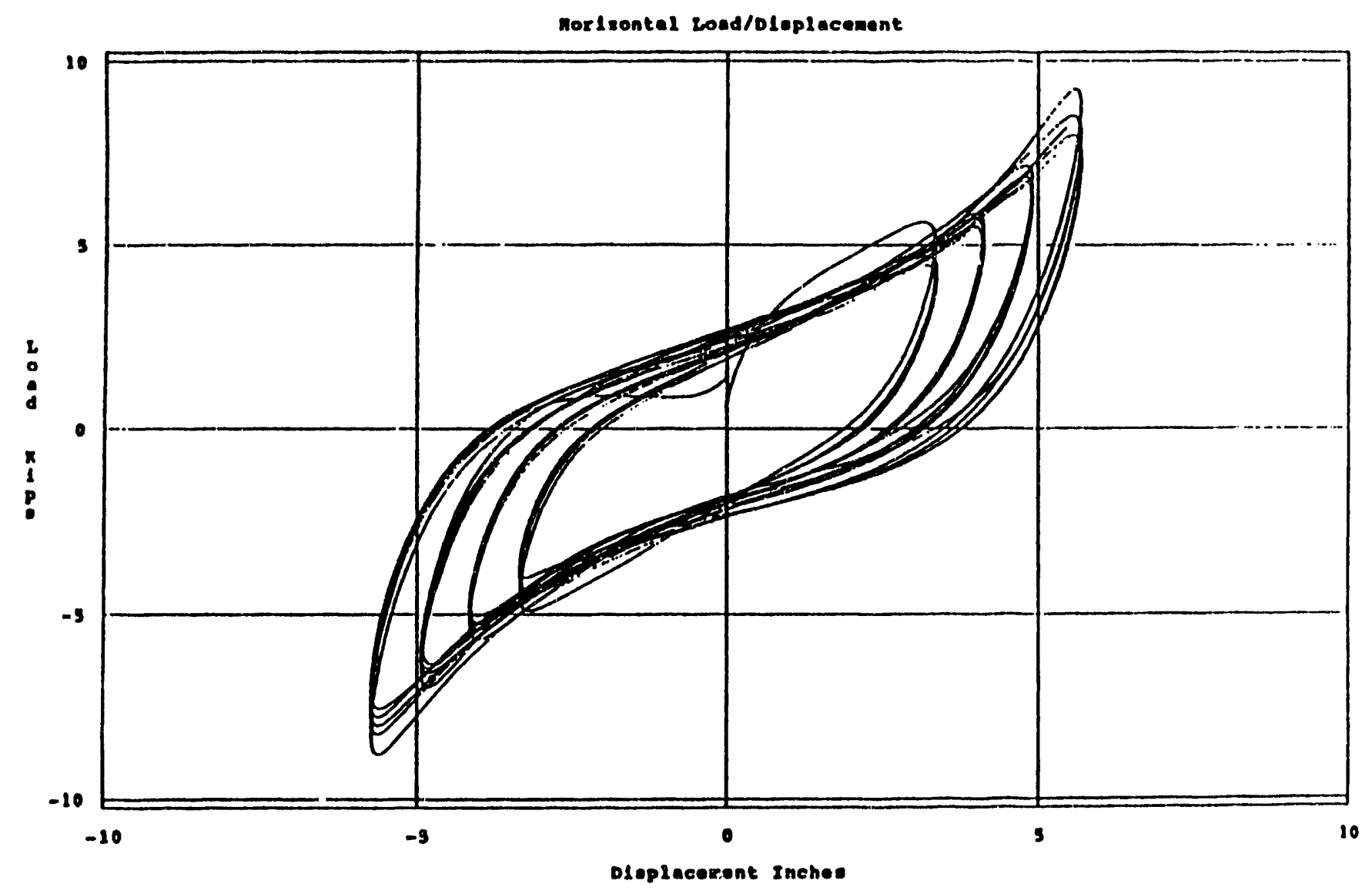

Fig. 16. Force Displacement Plots for Sequence III Tests - 10.35 MPa Vertical Pressure 


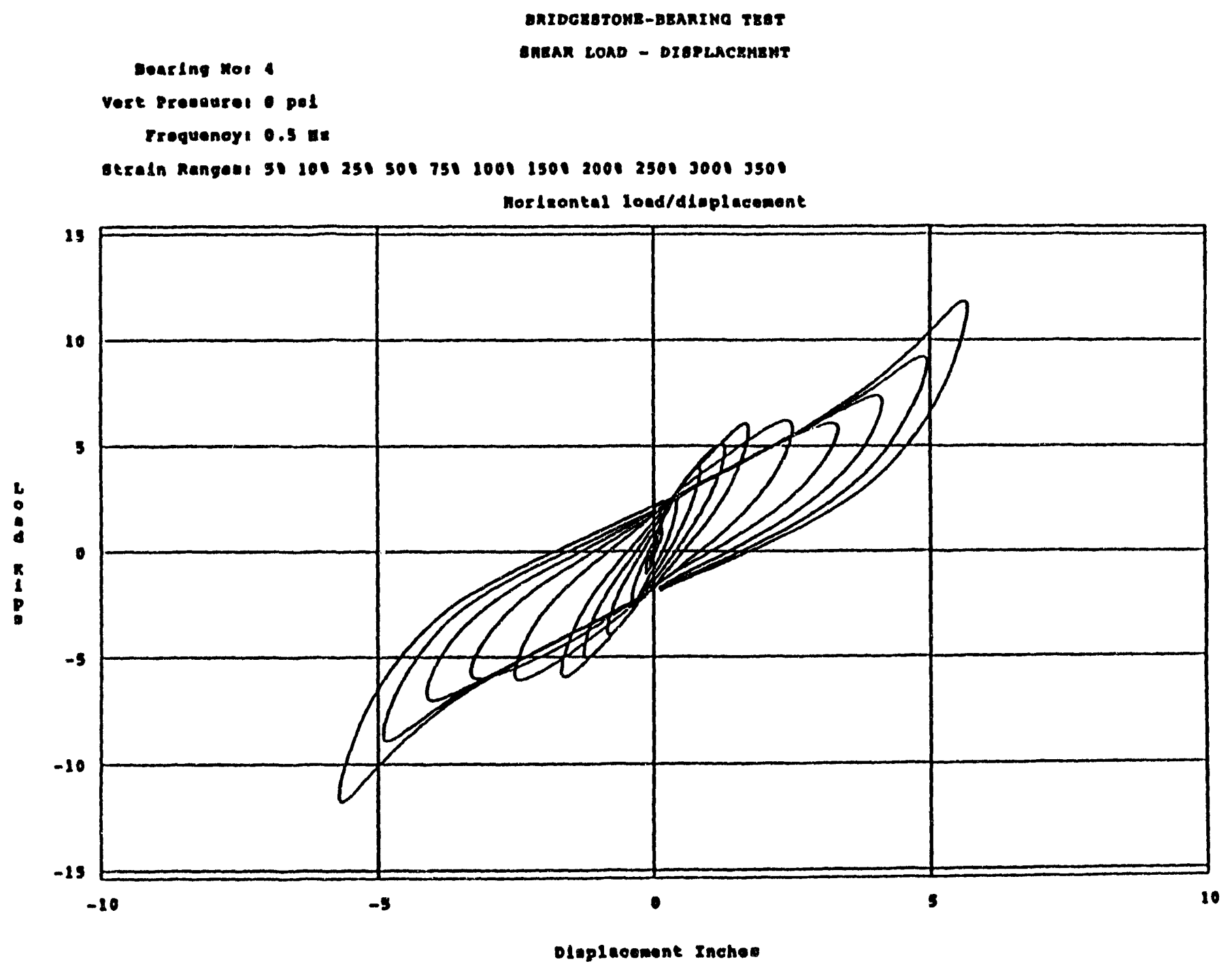

Fig. 17. First Cycle Force Displacement Plots at Different Strain Levels Under Zero Vertical Pressure 


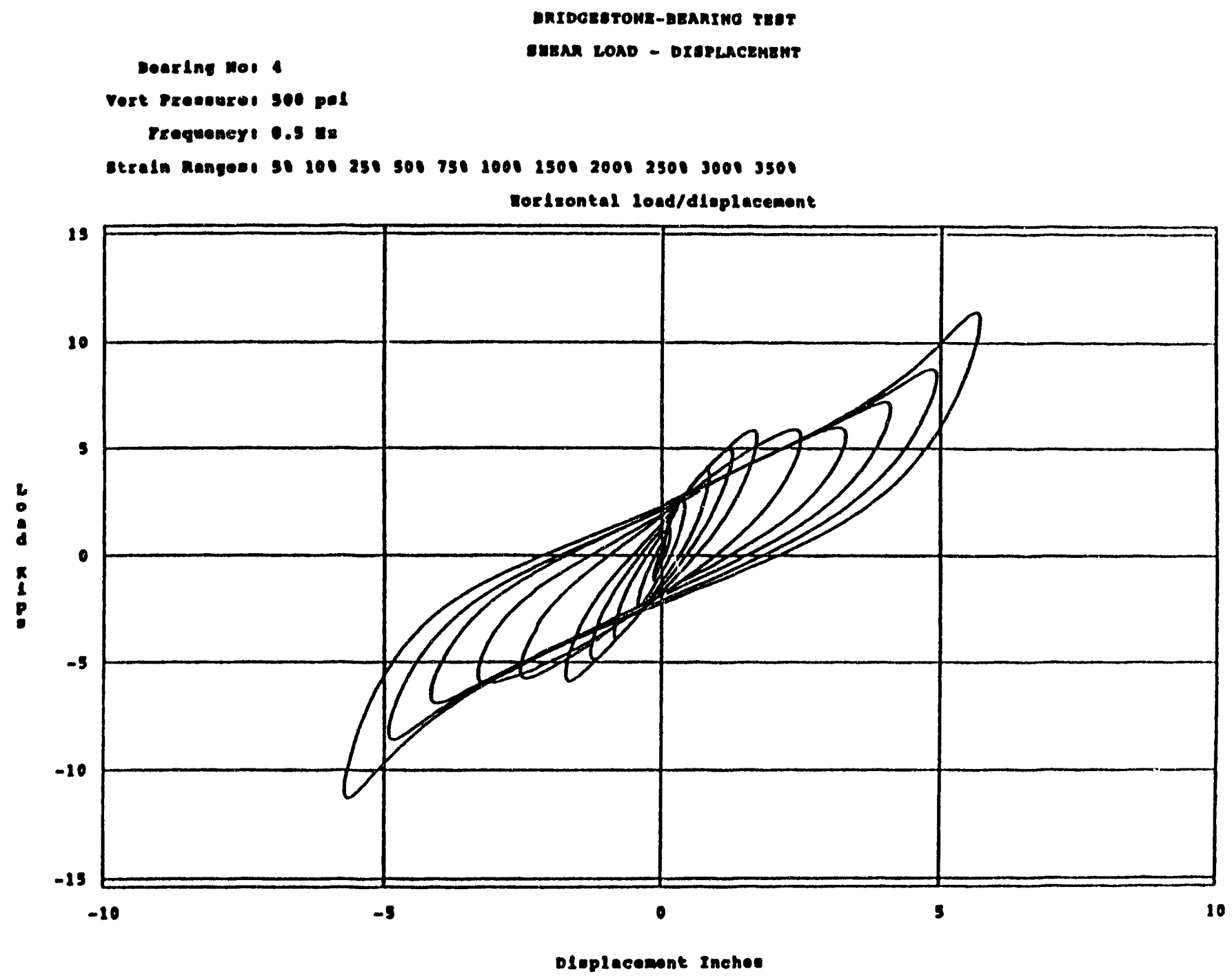

Fig. 18. First Cycle Force Displacement Plots at Different Strain Levels Under $3.45 \mathrm{MPa}$ Vertical Pressure 


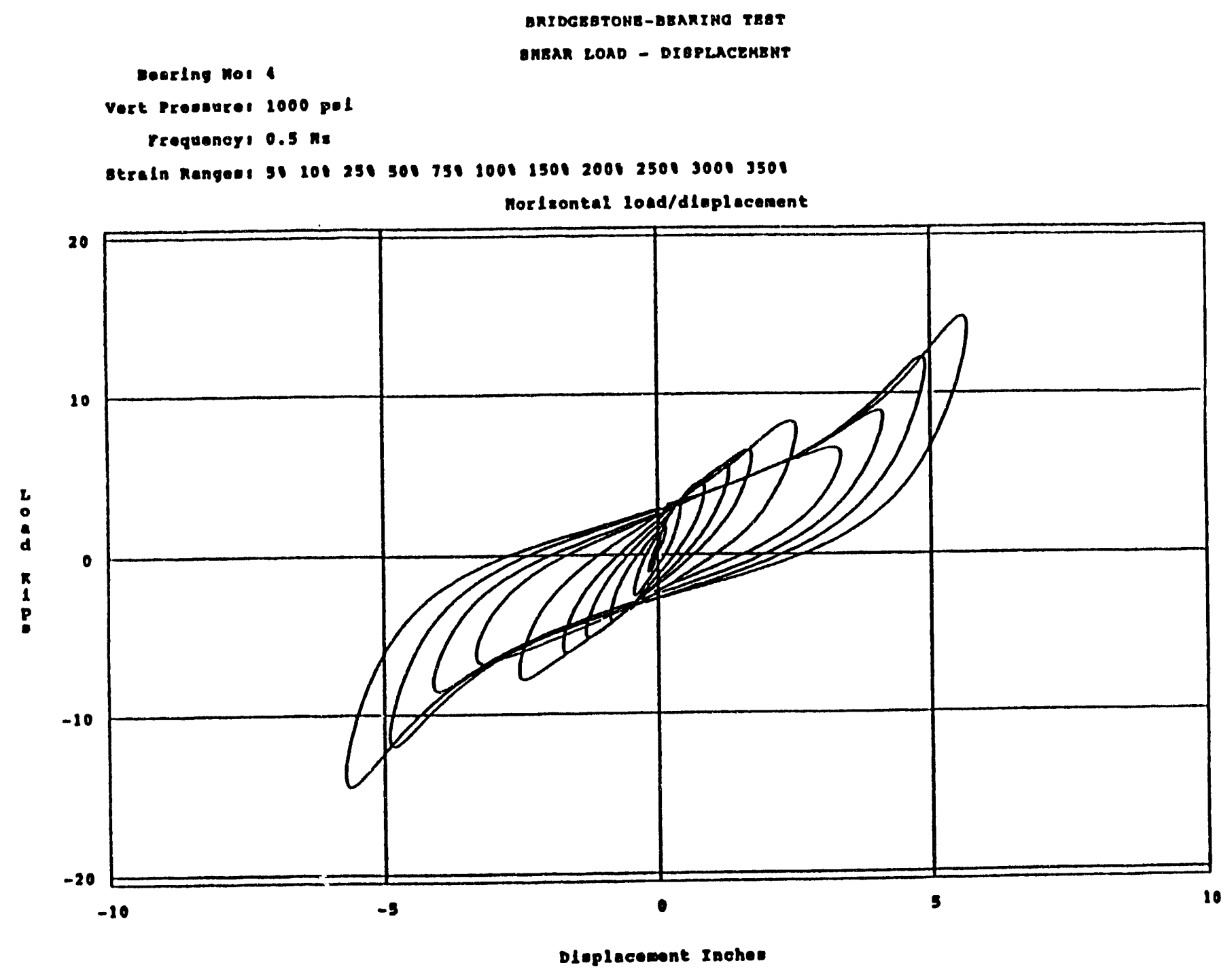

Fig. 19. First Cycle Force Displacement Plots at Different Strain Levels Under 6.90 MPa Vertical Pressure 


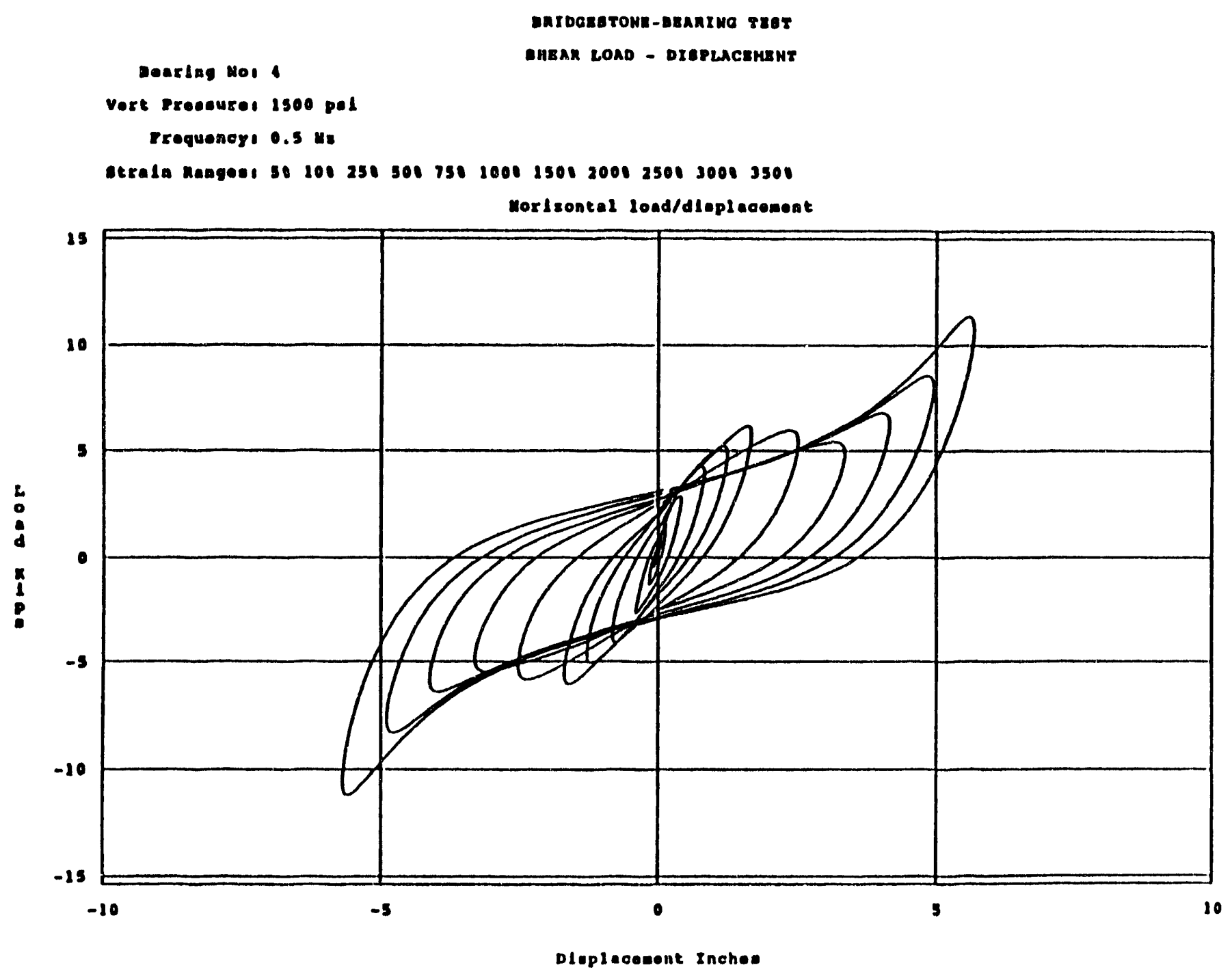

Fig. 20. First Cycle Force Displacement Plots at Different Strain Levels Under $10.35 \mathrm{MPa}$ Vertical Pressure 


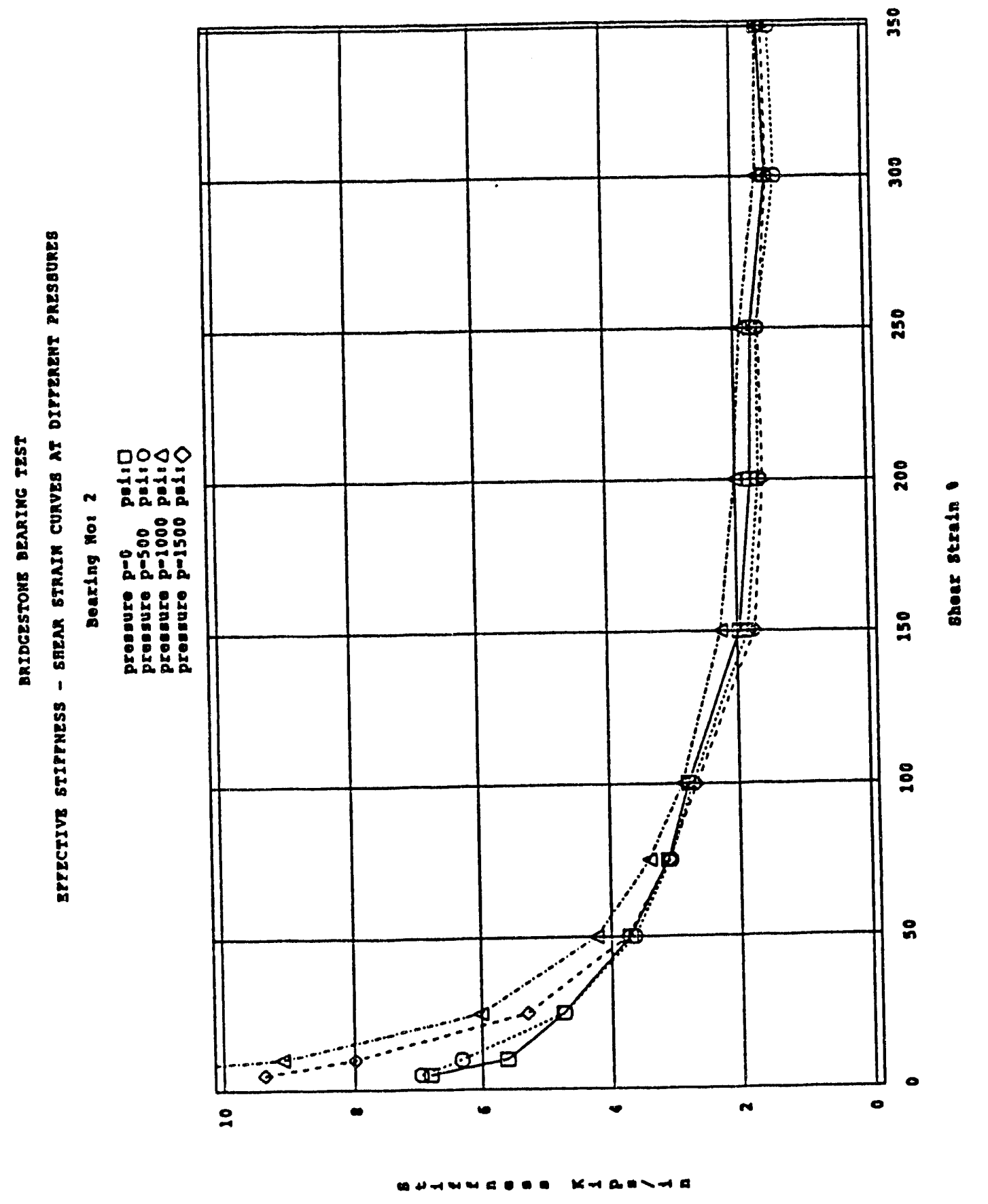

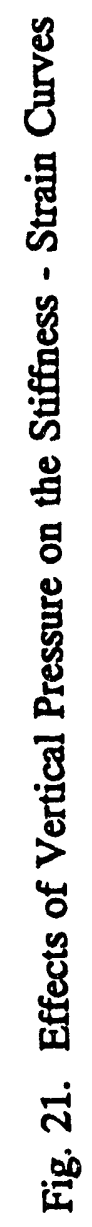




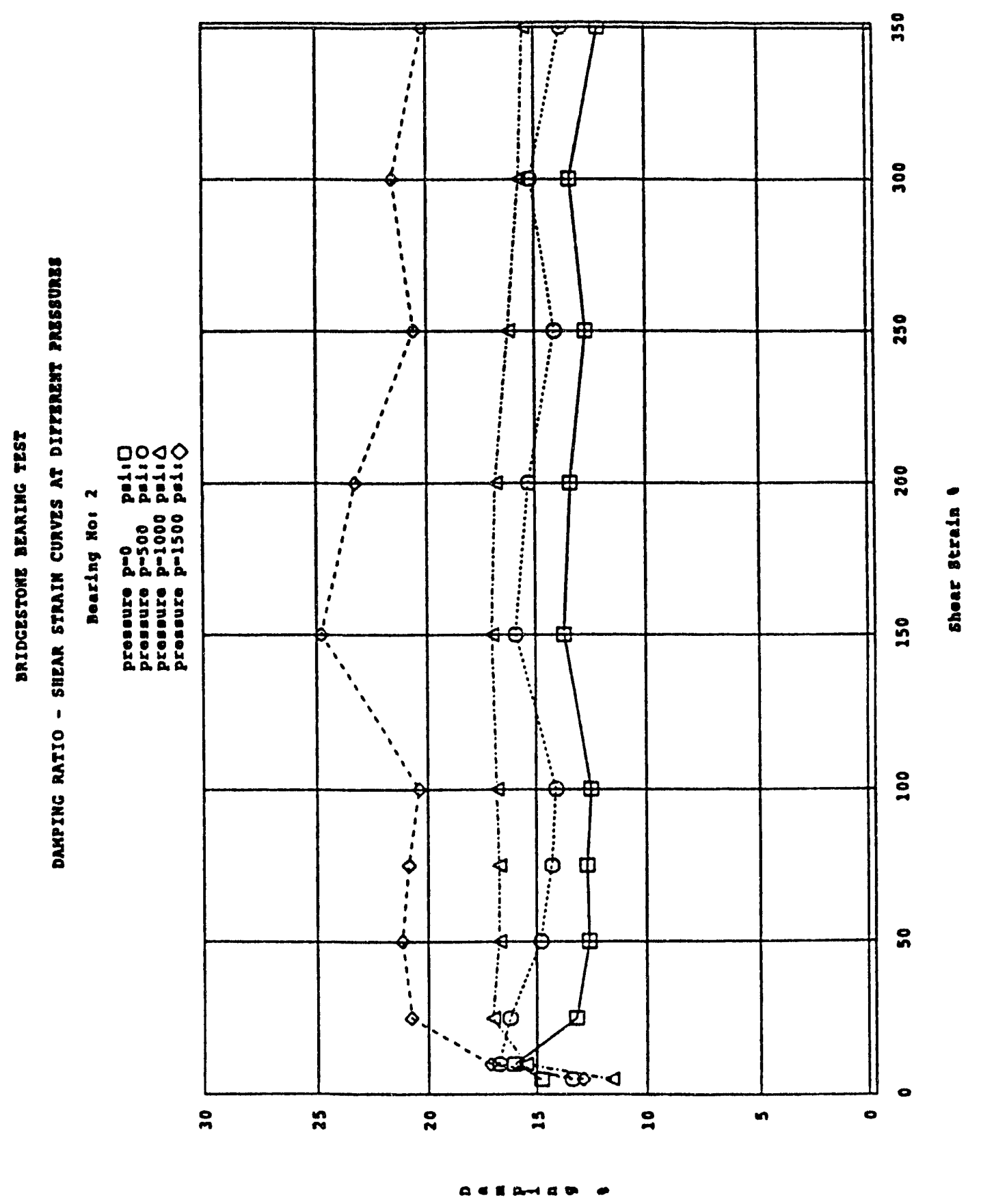

ป 


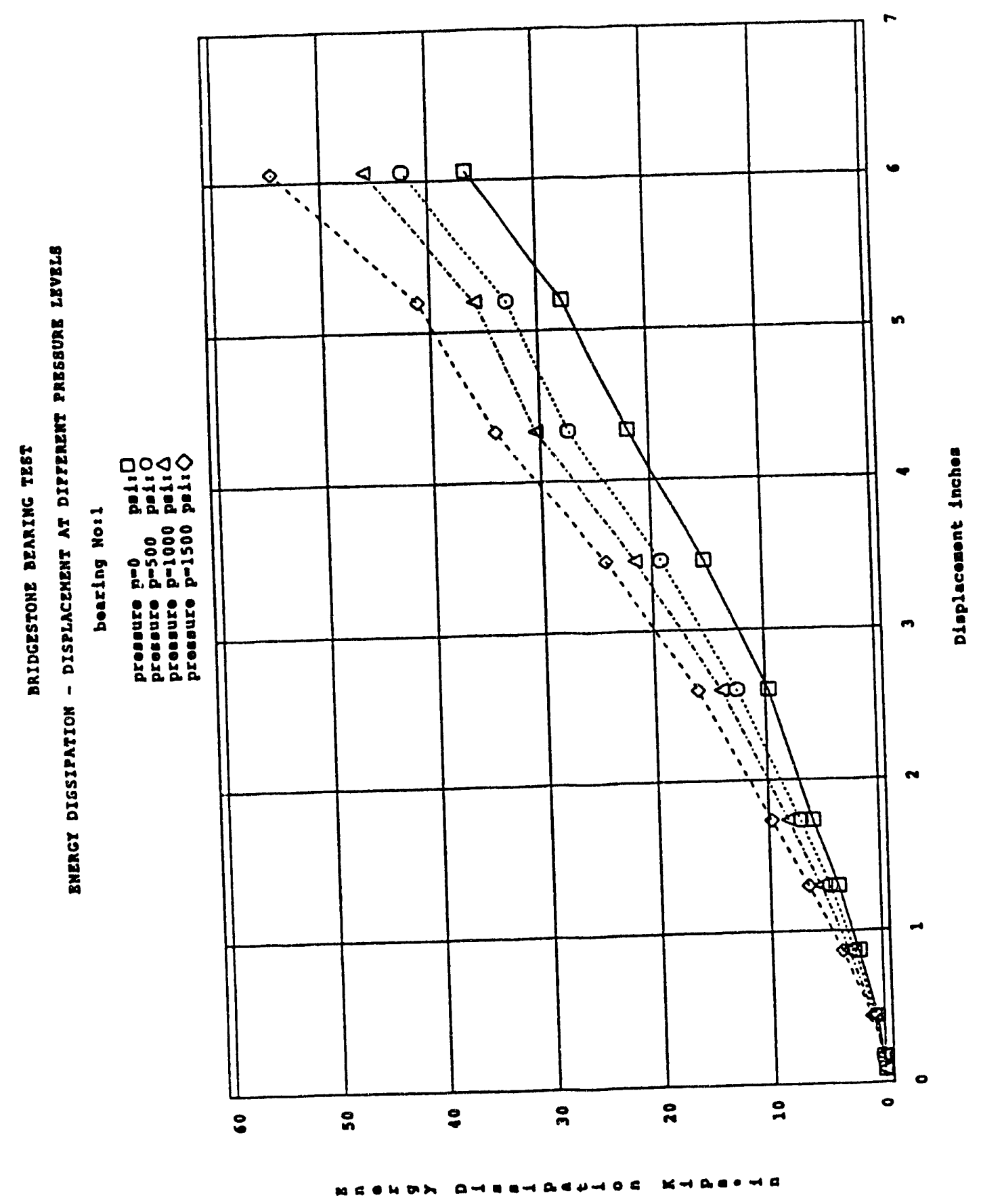

己̊

몸

3

호

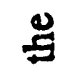

뭉

氙 

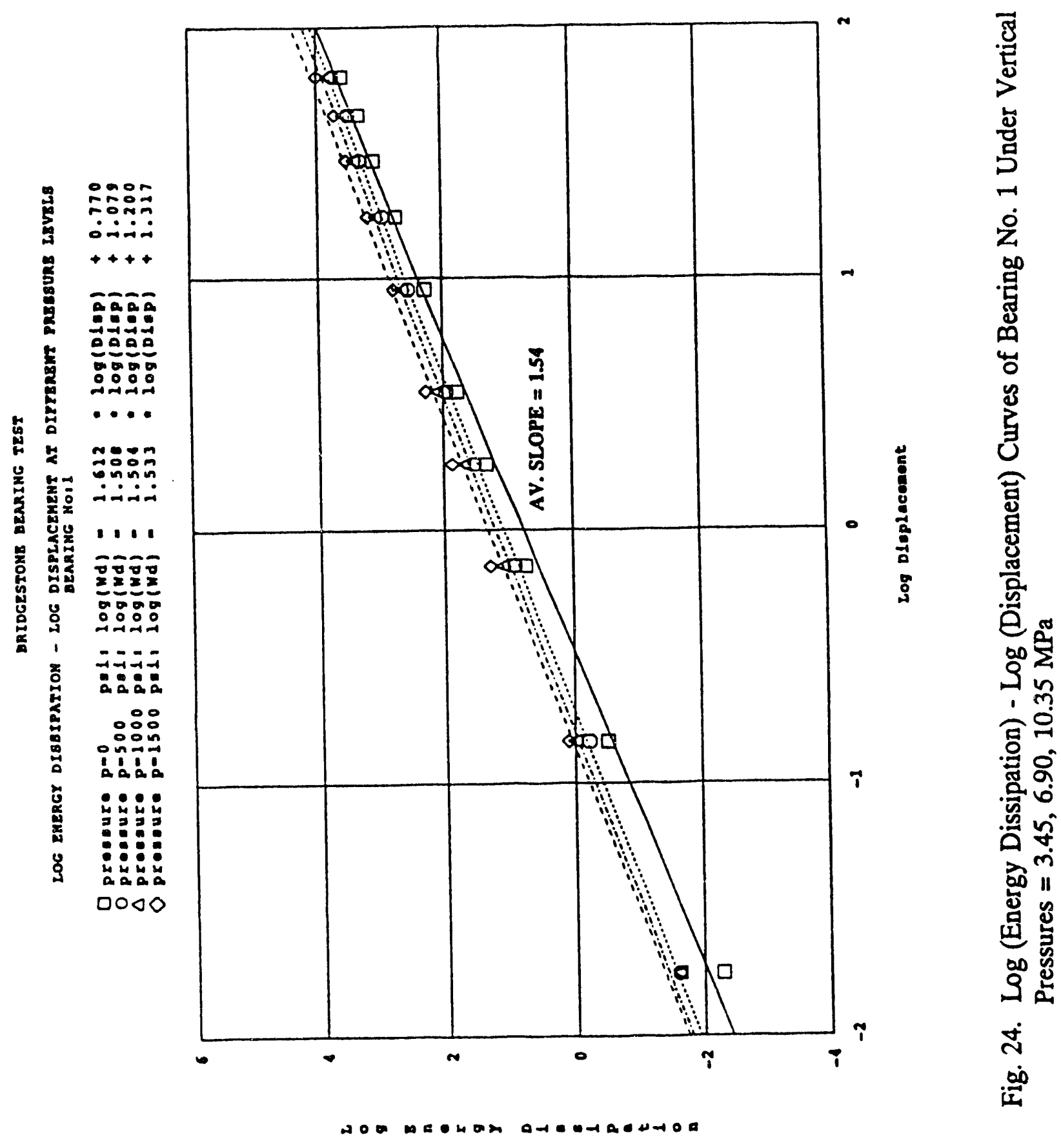

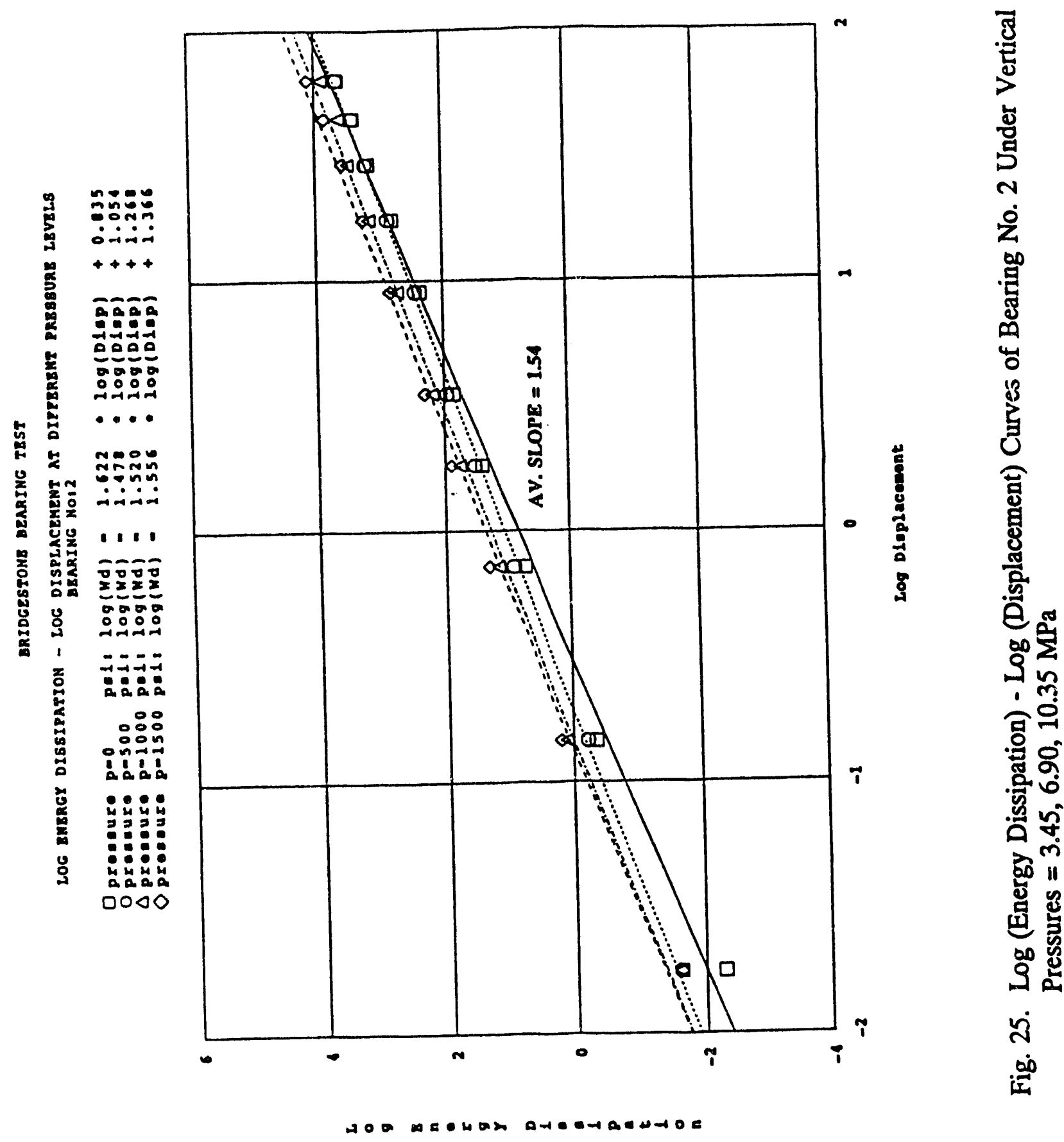

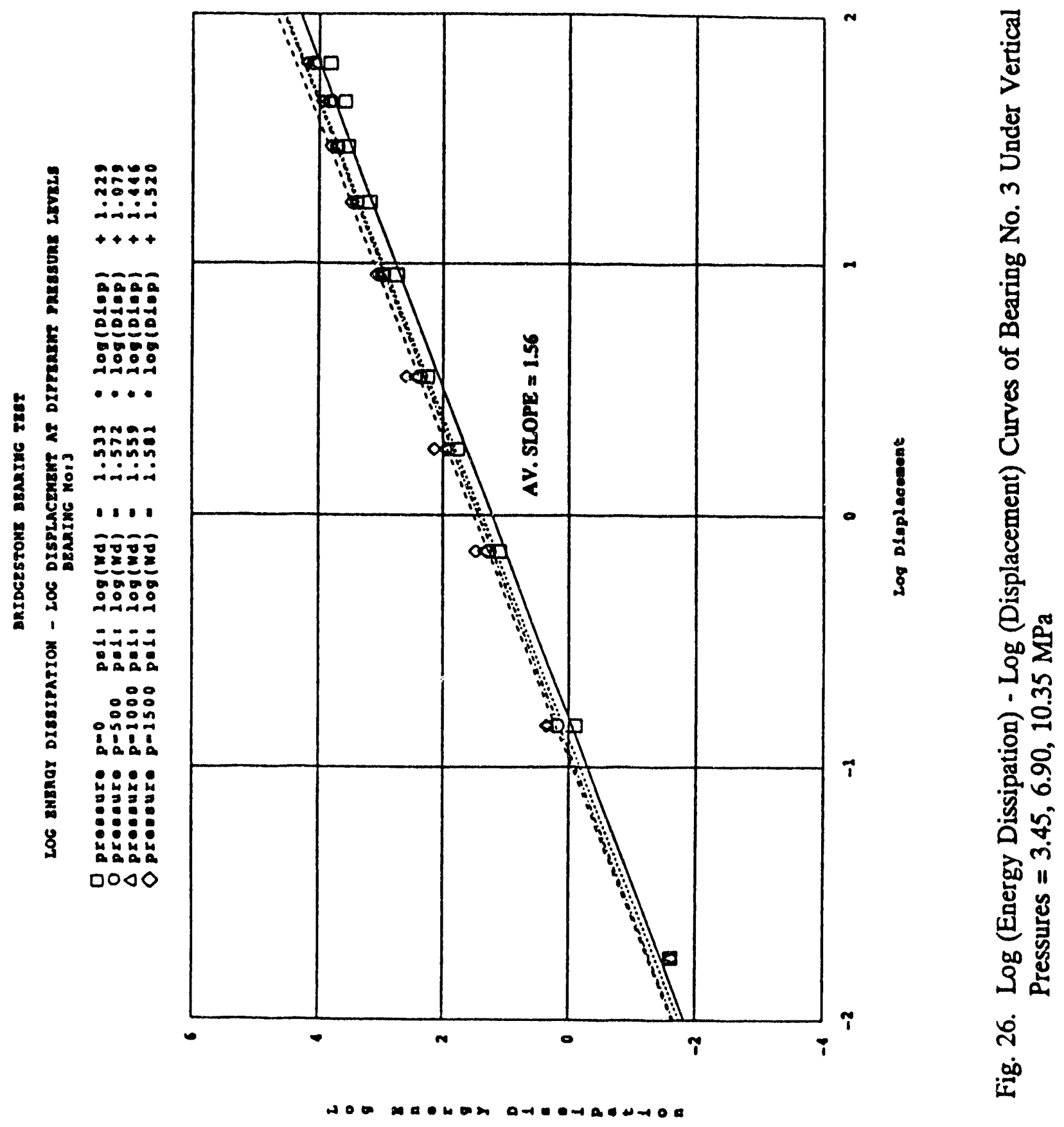

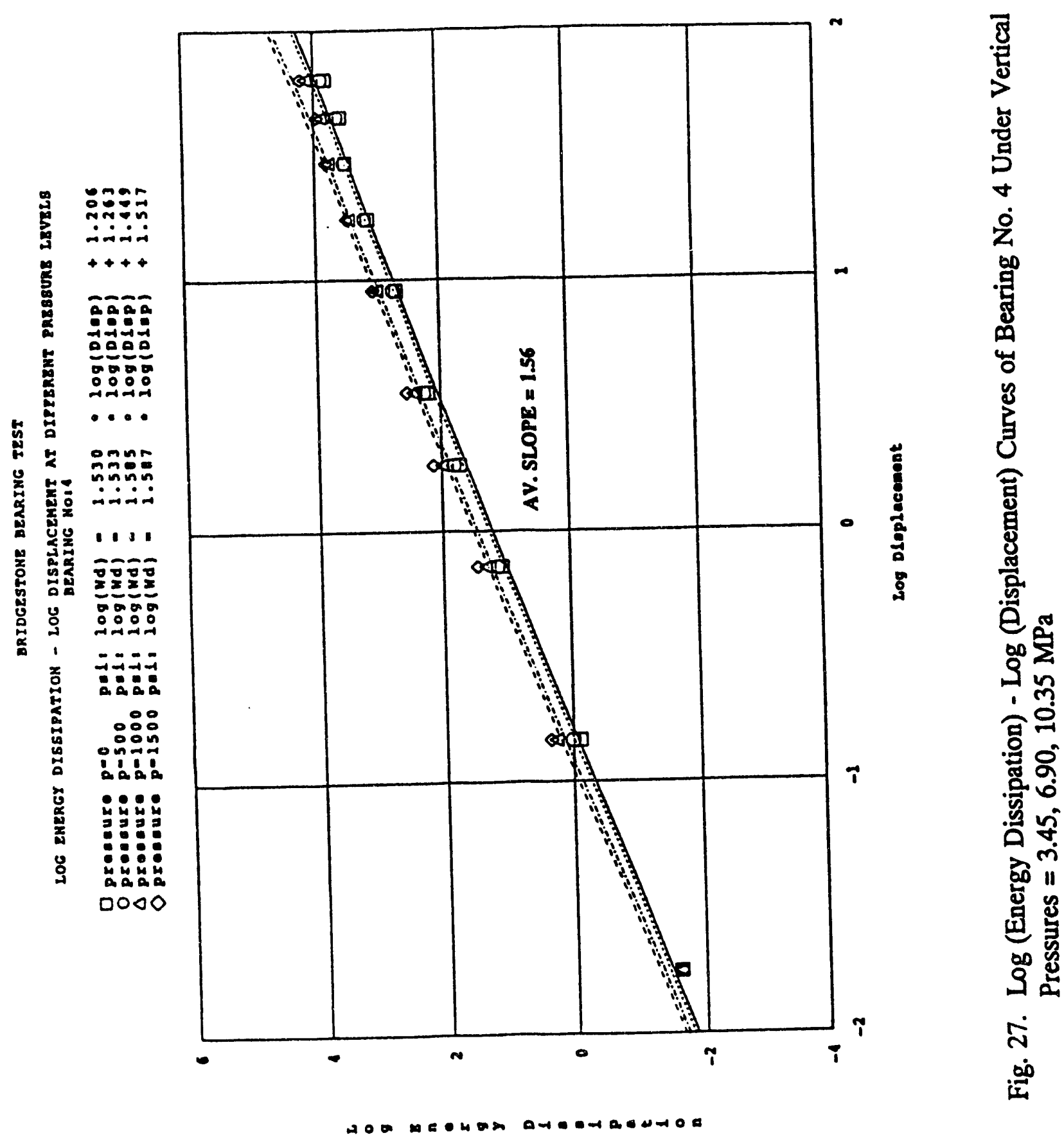


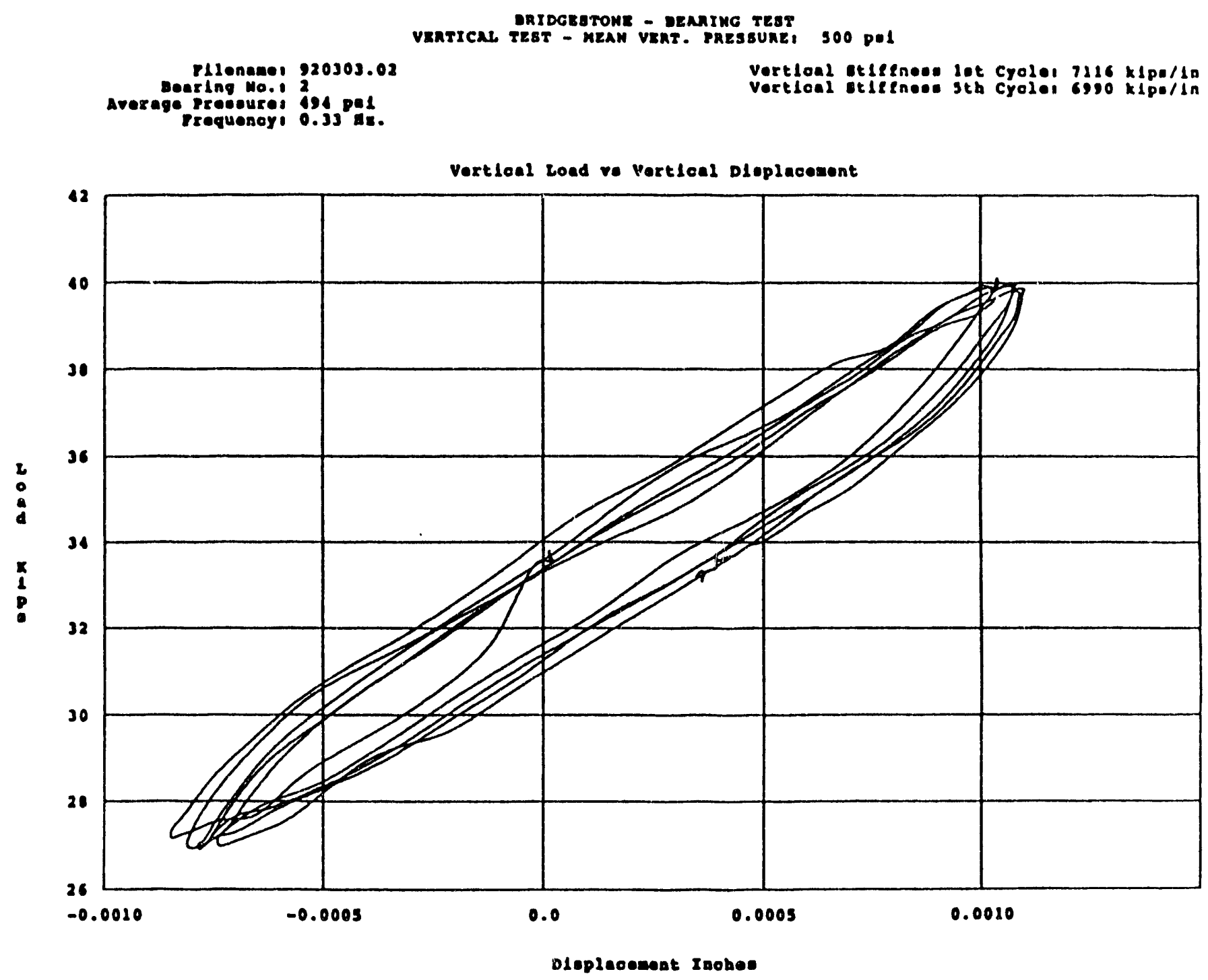

Fig. 28. Hysteresis Loops of Bearing No. 2 Under 3.45 MPa Vertical Pressure 


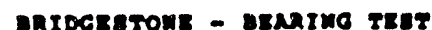

VARTical test - MEAN VIRT. PAEBEURE, $1000 \mathrm{pol}$

Doarlag 10.12

Arerage Preasurel 925 pol

requedor! 0.33 la.

Vertloel stlstoese let Crolel $9090 \mathrm{klpo/sa}$ vertical beletanes seh cyolei gio klpolla

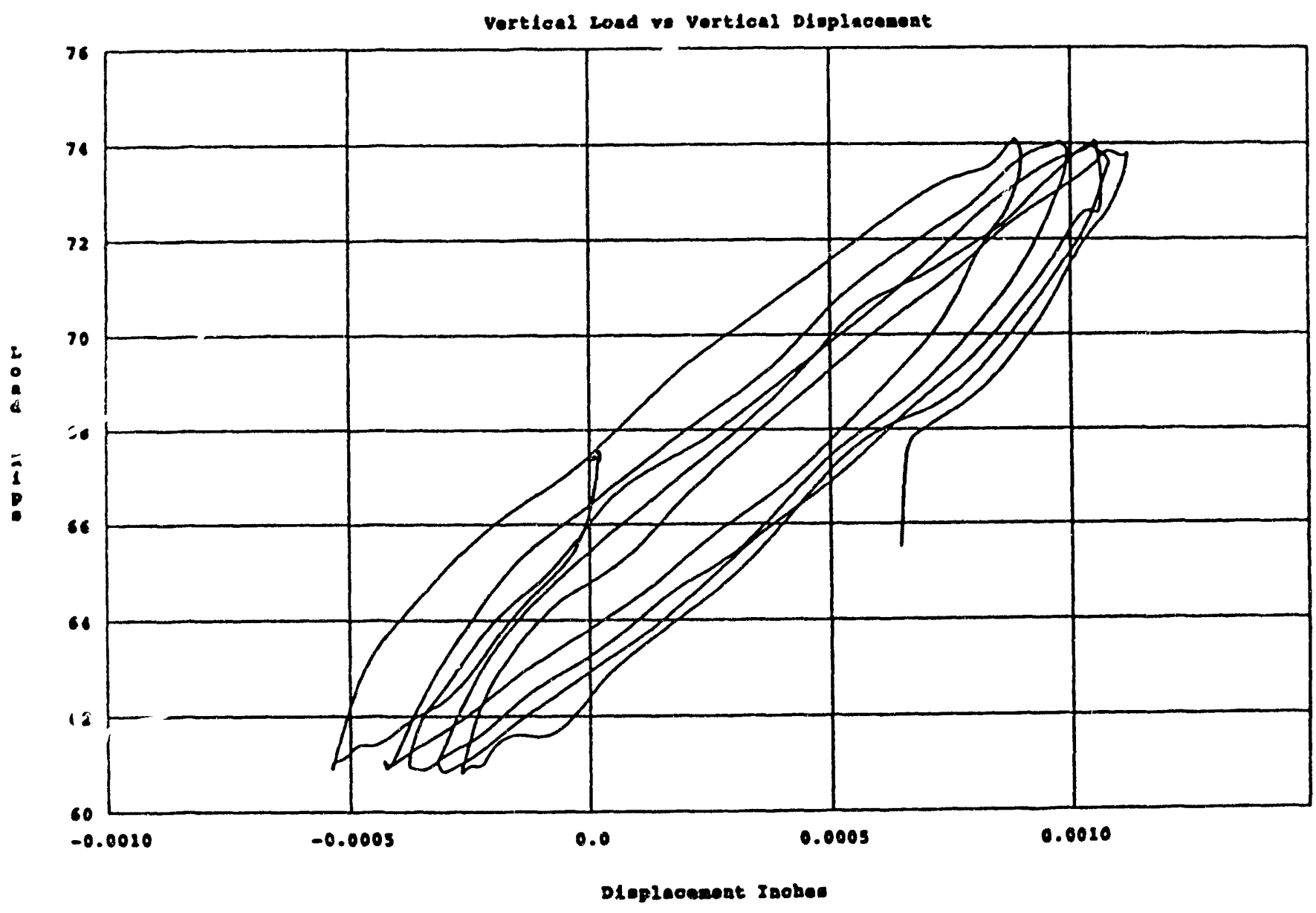

Fig. 29. Hysteresis Loops of Bearing No. 2 Under $6.90 \mathrm{MPa}$ Vertical Pressure 


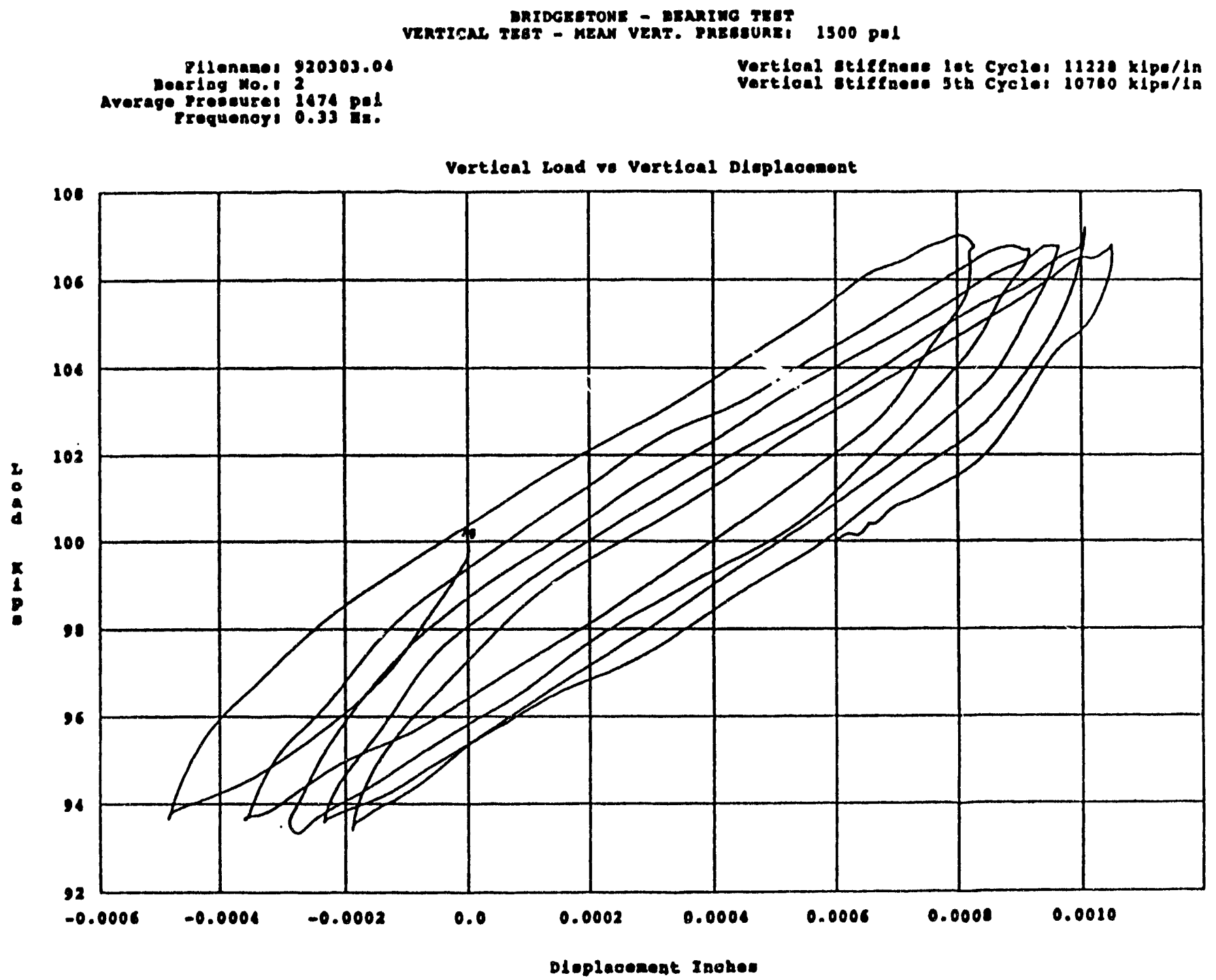

Fig. 30. Hysteresis Loops of Bearing No. 2 Under 10.35 MPa Vertical Pressure 


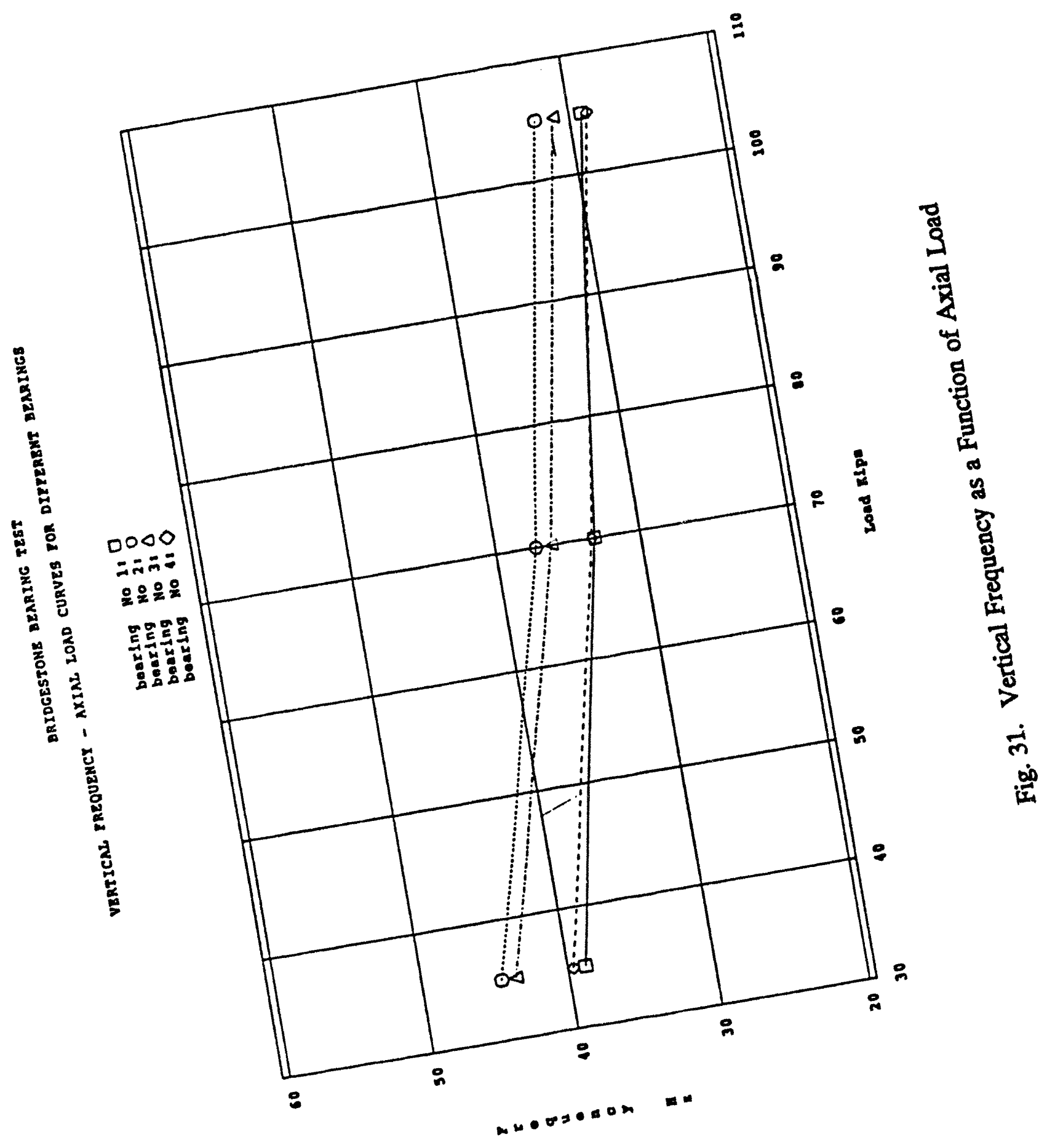




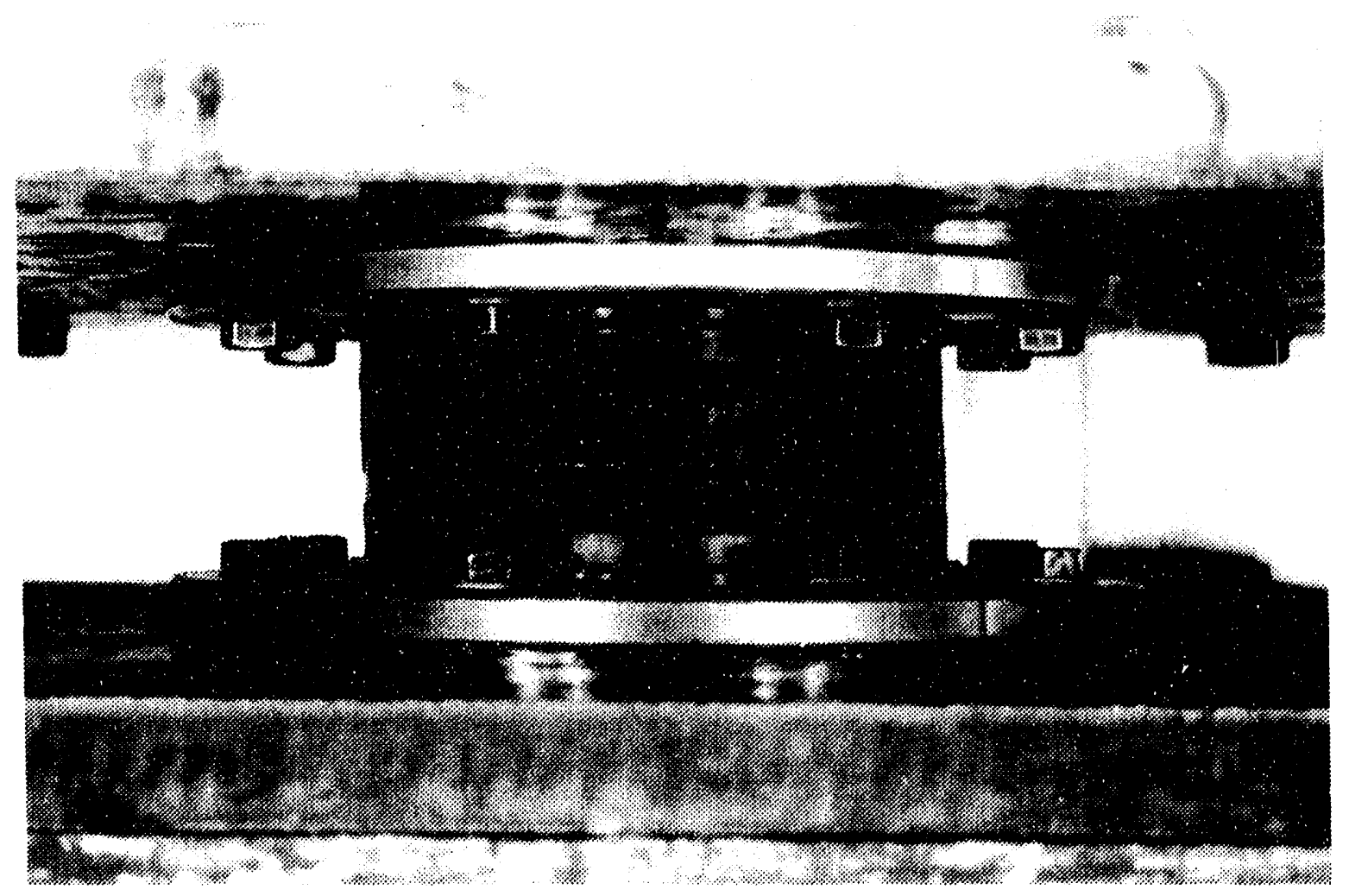

Fig. 32. Configuration of the Bearing at $0 \%$ Deformation

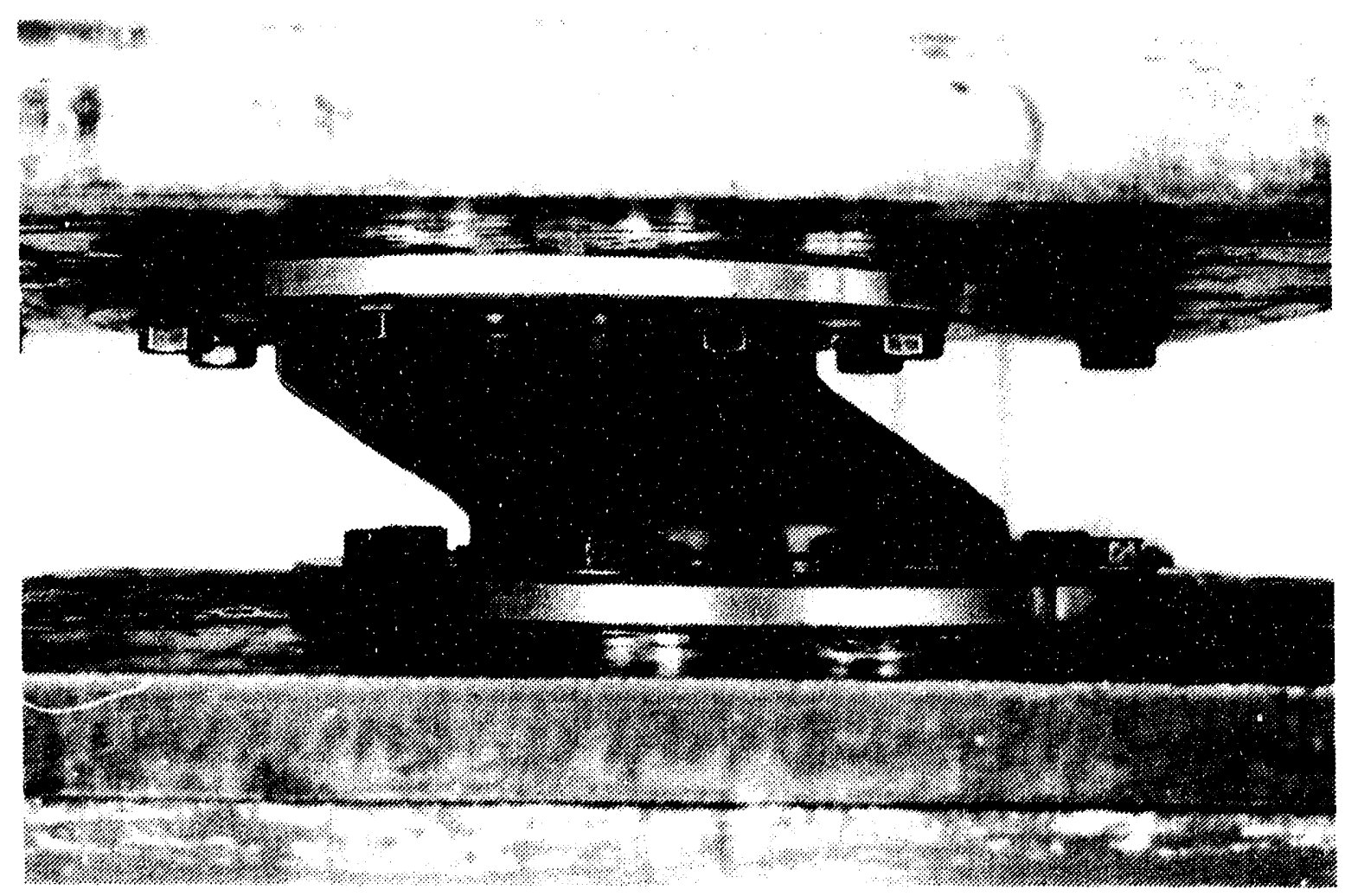

Fig. 33. Configuration of the Bearing at $200 \%$ Deformation 


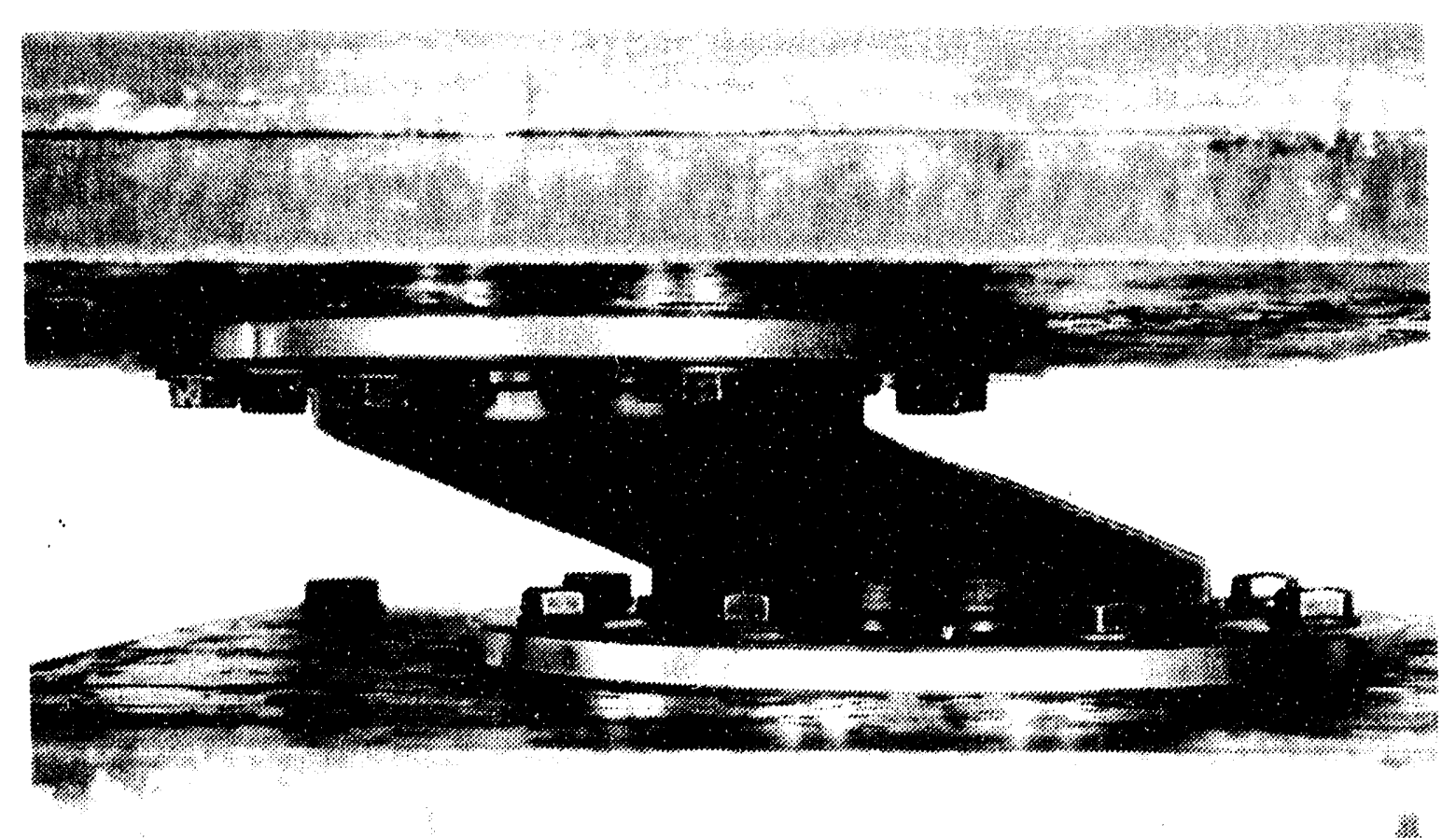

Fig. 34. Configuration of the Bearing at $350 \%$ Deformation

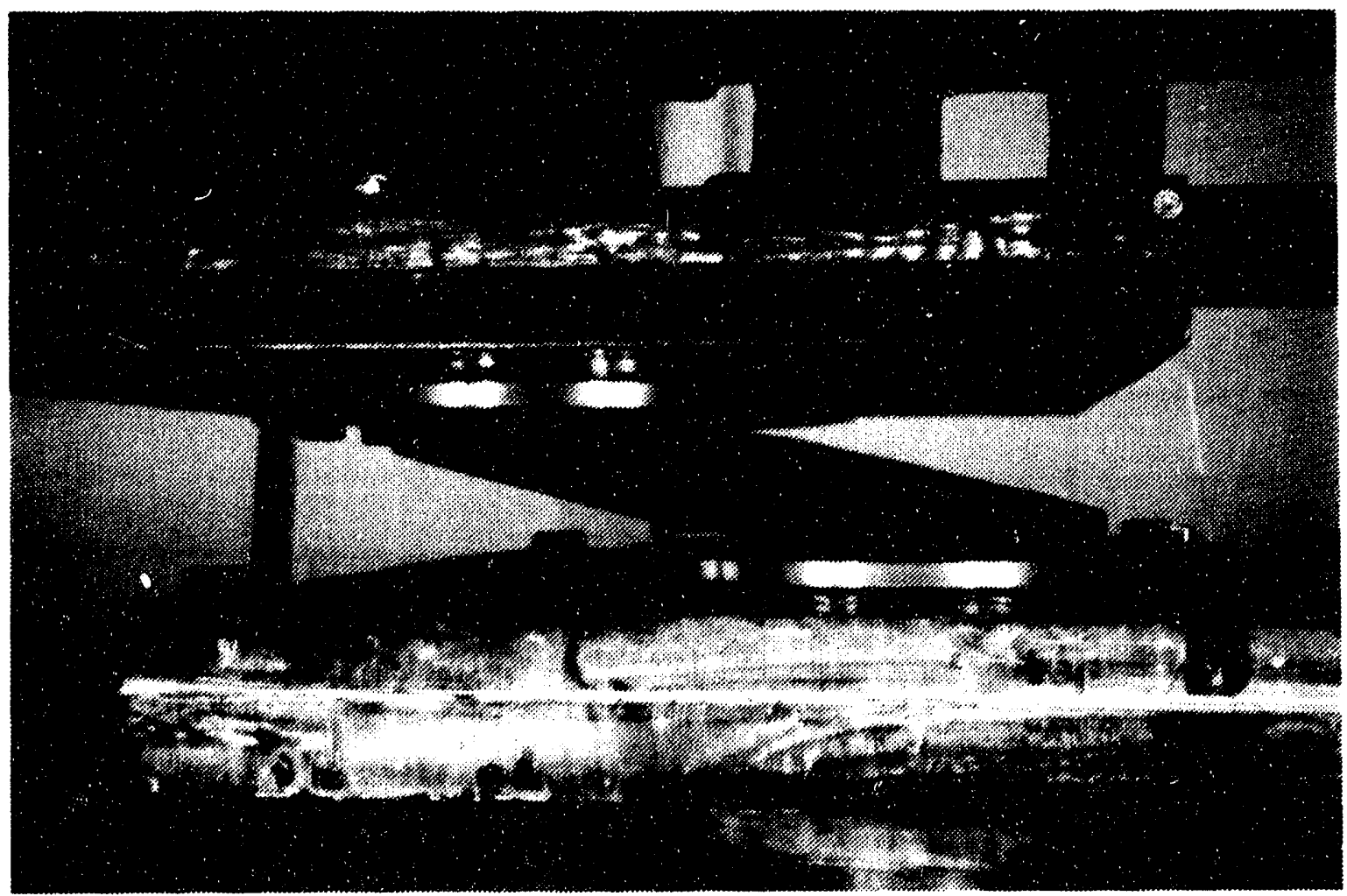

Fig. 35. Configuration of the Bearing at $600 \%$ Deformation 


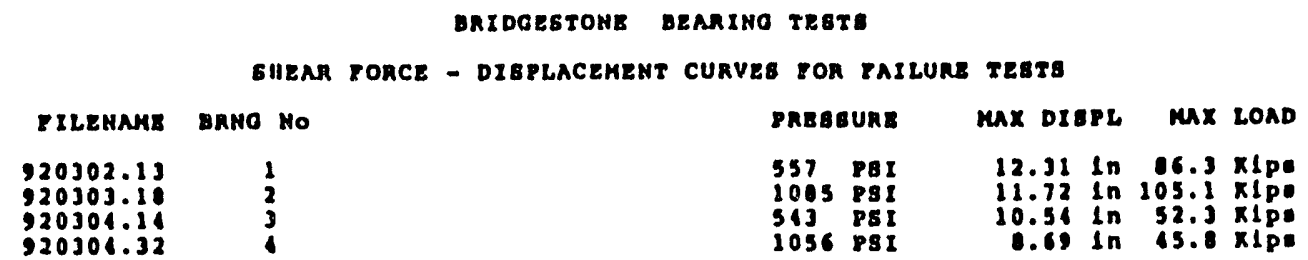

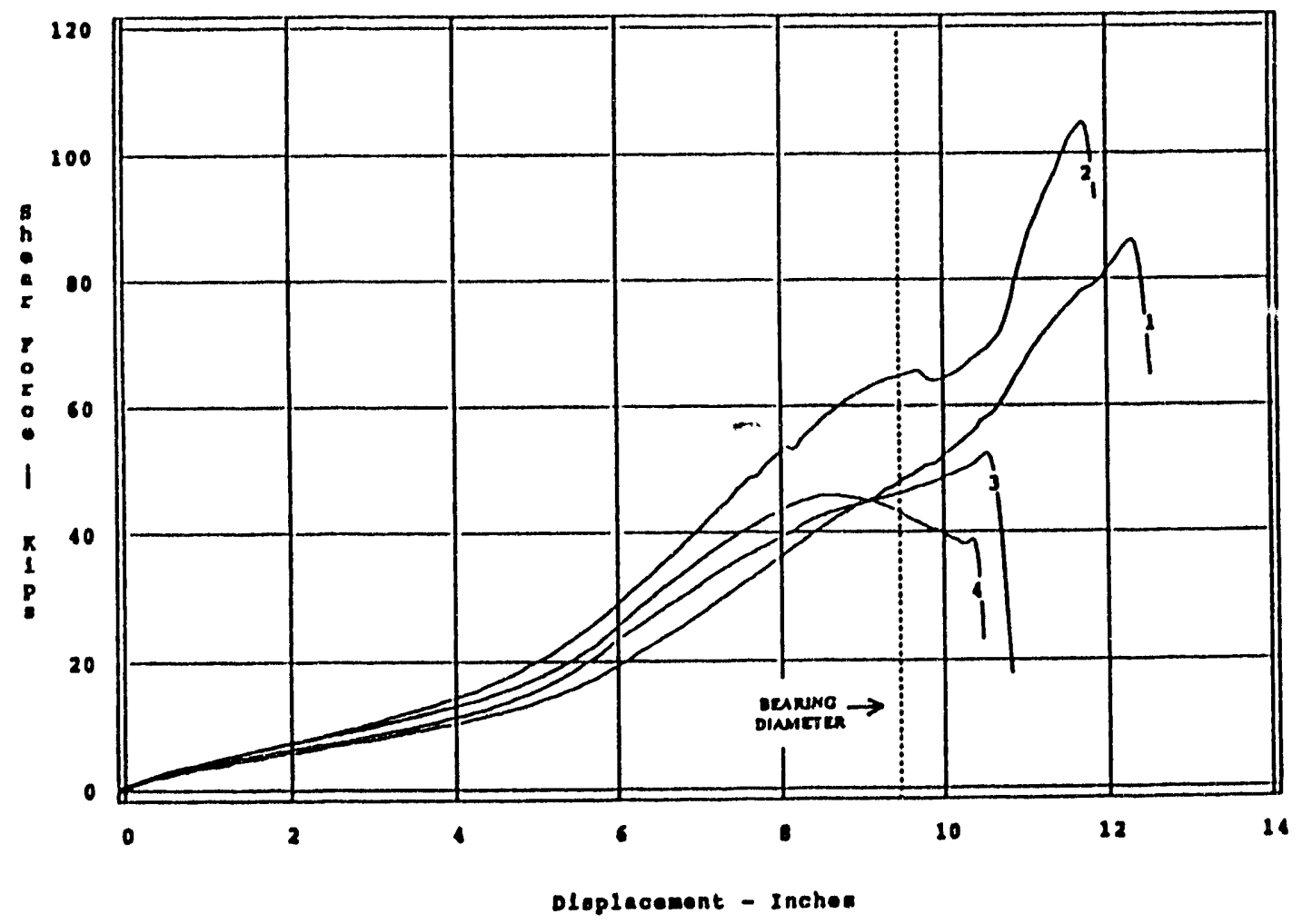

Fig. 36. Force-Displacement Curves for Bearings in Failure Tests 


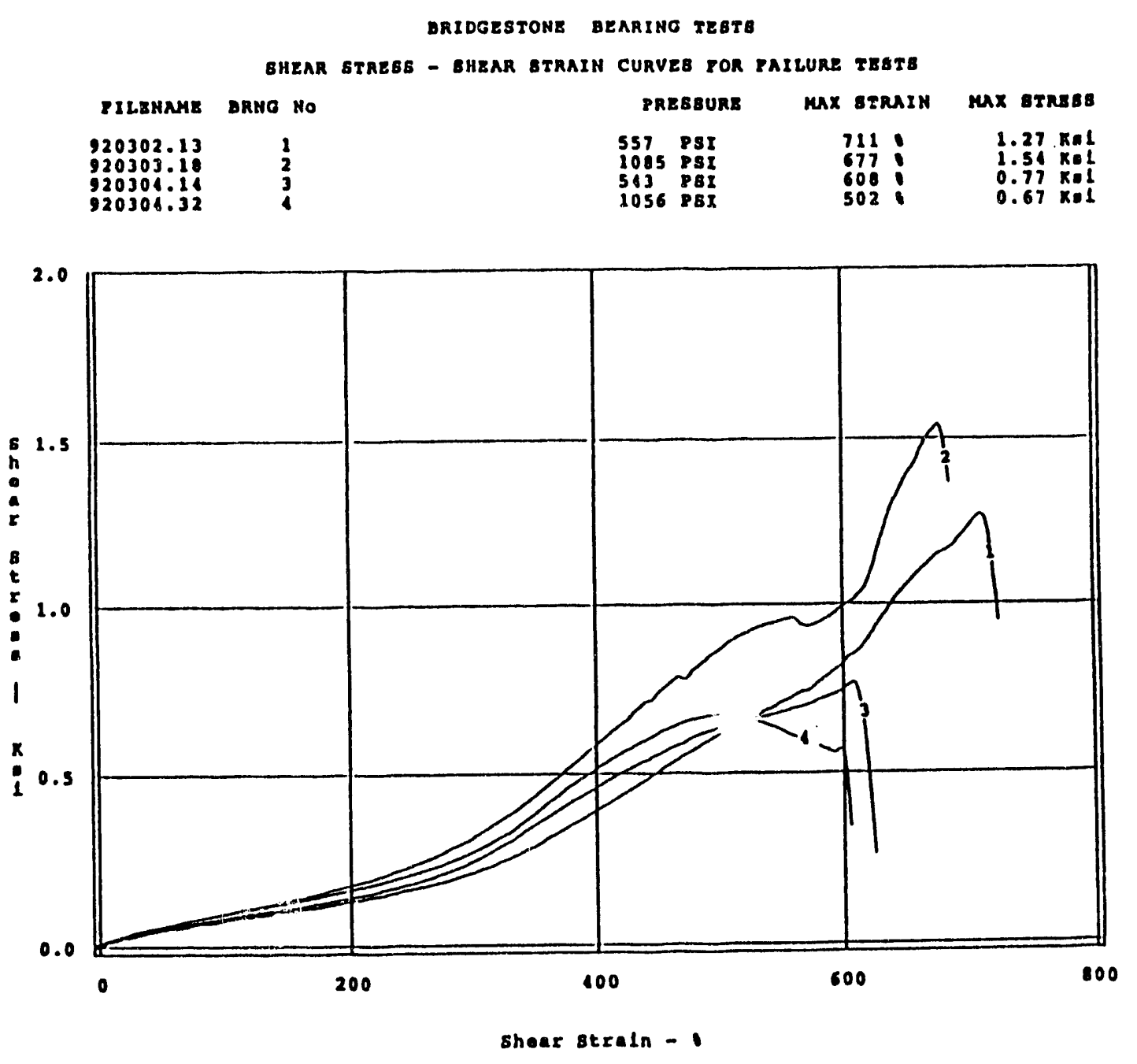

Fig. 37. Stress-Strain Curves for Bearings in Failure Tests 


\section{APPENDIX A}

\section{Experimental Determination of the Effective Stiffness and the Equivalent Damping Constant}

As indicated, the relation between force and displacement parameters for a linear viscouselastic model is of the following type:

$$
f=k \delta+c \delta
$$

where $\mathbf{k}=$ stiffness constant

$\mathrm{c}$ = damping constant

$\delta=$ displacement

$\delta=$ displacement velocity.

If a sinusoidal displacement is imposed on such a model, i.e.

$$
\delta(t)=\delta_{0} \sin \omega t
$$

then the corresponding force is

$$
f=\delta_{0}(k \sin \omega t+c \omega \cos \omega t)
$$

The maximum value of force is given by the value of $\omega t$ for which $\dot{f}=0$, namely,

$$
\tan \omega t=\frac{k}{c \omega}
$$

and is

$$
f_{\max }=k \delta_{0} \sqrt{1+\left(\frac{c \omega}{k}\right)^{2}}
$$

Since $f_{\max }$ is a quantity easily determined by the data collected during the test and $\delta_{0}$ is constant, the effective stiffness $K_{\text {eff }}=\frac{F_{\max }}{\delta_{0}}$ can then be determined. 


\section{A-2}

From Eq. (A.1) it follows that the effective stiffness is

$$
K_{e f f}=\frac{F_{\max }}{\delta_{0}}=k \sqrt{1+\left(\frac{c \omega}{k}\right)^{2}}
$$

If we solve this equation for $k$ we obtain:

$$
\mathrm{k}=\sqrt{\mathrm{K}_{\text {off }}^{2}-(\mathrm{c} \omega)^{2}}
$$

On the other hand, the energy dissipated in one complete cycle is

$$
W_{d}=\int_{0}^{2 \pi / \omega} F(t) \delta(t) d t=\pi c \omega \delta_{0}^{2}
$$

Since $W_{d}$ (area of the hysteresis loop) and $K_{\text {eff }}$ are easily measurable in an experimental test, as already indicated, it is possible using Eqs. (A.2) and (A.3) to determine the values of the stiffness constant $\mathrm{k}$ and the damping constant $\mathrm{c}$ of the viscous-elastic model equivalent to the real model.

It is interesting to note that the equivalent viscous-elastic model, as defined above, dissipates the same energy per cycle as the real model and provides the exact estimate of the maximum force exerted.

Furthermore, it is easy to verify from Eq. (A.2) that for low damping values the stiffness constant $k$ is not very far apart from $\mathrm{K}_{\text {eff }}$.

In fact, when the error is defined as follows:

$$
\varepsilon=\frac{K_{e f f}-k}{k}
$$

it follows that

$$
\varepsilon=-1+\sqrt{1+\left(2 \beta \frac{\omega}{\omega_{0}}\right)^{2}}
$$




\section{A-3}

where $\omega_{0}=$ fundamental frequency

$\beta=\frac{c}{2 m \omega_{0}}$ (damping ratio).

If the experimental test is carried out under resonance conditions $\left(\omega=\omega_{0}\right)$, it follows that $\varepsilon=-1+\sqrt{1+(2 \beta)^{2}}$

It is obvious that there is no error if damping is zero, whereas for damping of $20 \%$ the error is less than $8 \%$.

It also seems clear that for typical damping values for the isolation device under investigation the error that is made using the approximate relation is within the uncertainty limits of experimental data and therefore negligible. 

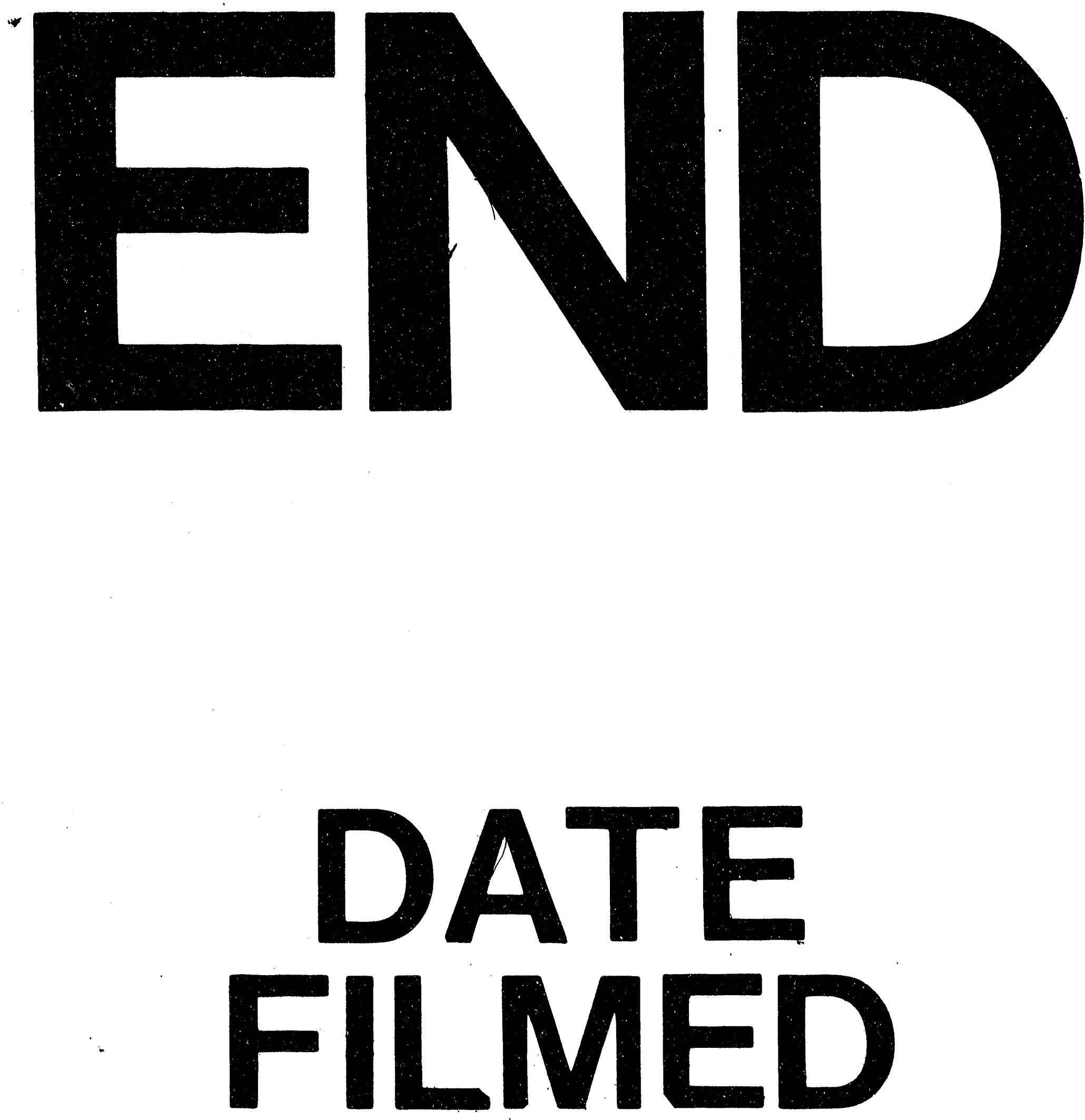

1

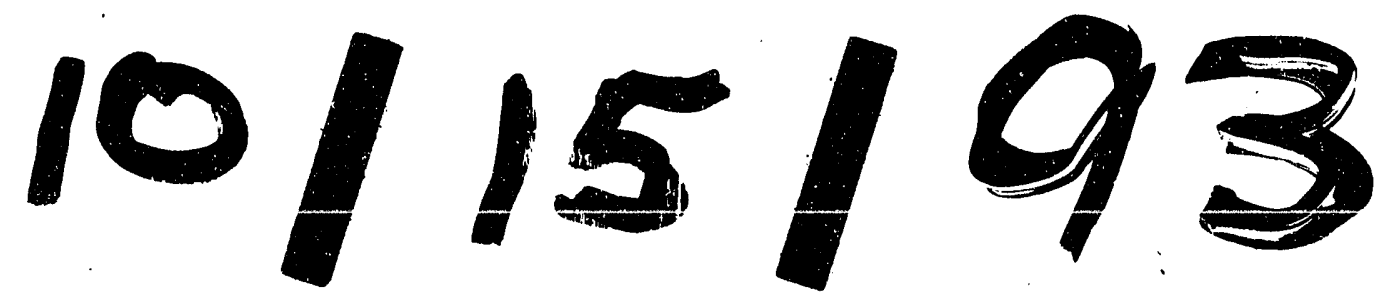


